\title{
Raising the Red Flag: The Continued Relevance of the Japanese Internment in the Post-Hamdi World
}

\author{
Aya Gruber*
}

I. INTRODUCTION

Most of what I have learned and internalized about the Japanese internment came from my mother, Mariko Hirata. My mother was just a young girl when her own government imprisoned her. Growing up, I heard all about the cold, the dirt, the embarrassing communal showers, the shame, and the guns. My mother painted a picture of her family's perpetually dusty tar-paper shack, where they slept five to a room underneath oiled-paper windows in the dead of the Wyoming winter. At five years old, my mother played with the round horntoad droppings under the beds, believing they looked like little billiard balls. My mother recalled with ire observing her father taken away to pick potatoes, accompanied by armed soldiers. ${ }^{1}$ She related with sorrow the taunts of the white children from outside the barbed wire and fences, while like a Kafka-esque vision, she and other Japanese children saluted the American flag. She also told me about the prelude to and aftermath of

* Associate Professor of Law, Florida International University College of Law; J.D., Harvard Law School magna cum laude; B.A., U.C. Berkeley summa cum laude; Assistant Public Defender, Washington, D.C.; Assistant Federal Defender, Southern District of Florida. This Article is dedicated to the members of my family who suffered through the internment: Mariko Hirata, Mutsu Onaga, Toshi Abbott, Yoshinori Hirata, Nuiko Hirata, Ray Hirata, and Rumi Hirata, as well as the thousands of other families who suffered. This Article is also for the thousands of families, especially in the Arab world, currently distressed over their loved ones in U.S. detention. I further dedicate this work to Fred Korematsu, a hero and champion of liberties for people of all races, who recently passed away. I thank the FIU College of Law faculty and administration for their support and ideas, particularly Thomas Baker, Jorge Esquirol, Karen Pita Loor, Leonard Strickman, and Ediberto Roman for their advice on previous drafts. I also appreciate the input of Luis Salas, John Stack, and Robert Chesney on terrorism and related issues. Finally, I must praise the diligent work done by my research assistant, Daniel Cruz and editors, Leita Walker and Rebecca Martin.

1. Internee William Kochiyama recalls that at the entrance of the assembly center "'stood two lines of troops with rifles and fixed bayonets pointed at the evacuees." THE COMMISSION ON Wartime Relocation and Internment of Civilians, Personal Justice Denied 136 (1982) (hereinafter INTERNMENT OF CIVILIANS) (quoting William Kochiyama). 
the internment: The pain her family felt in leaving their home, only permitted to bring a few solitary belongings, and reporting to a relocation center with the trepidation of a family whose fate was unknown. She recounted the extreme desperation and despair her family felt when, upon release, they lived in abject poverty in a boarding house, having been stripped of their home, land, and possessions. ${ }^{2}$

In 1988 The Miami News ran an article on the Japanese reparations bill, which had just been signed into law by President Reagan, and interviewed my mother. Her interview demonstrated the lingering pain of internment:

For Marie Gruber, the internment camp was in Heart Mountain, Wyo., where she and her family lived in tar-paper shacks with wood floors.

"I was very young, but I could understand the gist of it from my parents. My father was worried that something was happening like over in Germany. 'Maybe they want to get us all together and then drop a bomb on us,' he'd say. But being 5 years old, a lot of it was 'I want to go out and play,' but we were in a barren desert near Cheyenne, Wyoming, in barracks surrounded by barbed wire," Gruber said.

She doesn't buy the grumbling about Pearl Harbor and American POWs. "Those people were directly affected by a war act one country perpetrated on another. This was our own government that did this to us.",

The sorrow and indignity of forced incarceration has remained for years in my family ${ }^{4}$ and the psyche of the Japanese-American community. ${ }^{5}$ At the time of the internment there was little resistance or

2. See Frank F. Chuman, The Bamboo People: The Law and Japanese-Americans $173-$ 74 (1976) (discussing property seizures during the internment).

3. Pete Collins, Justice Served by \$20,000 Payments to Internees, Miami News, Aug. 11, 1988, at 5A (quoting internee Marie Gruber).

4. My grandfather, Yoshinori Hirata, who was stripped of his farm land and sent into forced labor at gunpoint, passed away in 1980, long before the government's apology could reach his ears. Nuiko Hirata, my grandmother, is ailing, and for the first time in more than fifty years no longer remembers the pain, frustration, and embarrassment of internment. Up until her stroke a few months ago, she could recall with vivid accuracy how vigorously she scrubbed and scrubbed, but to no avail - their barrack in the camps never got clean. My aunt, Mutsu Onaga, was a teenager during the internment and, even now in her seventies, feels the anger and sorrow as if they were fresh. She still talks about the internment with vitriol - the lack of privacy, embarrassment, and frustration.

5. A fellow child of the internment, Michael Yoshii, explains how his parents' pain welled deep beneath the surface, stating,

"When I first learned of the internment as a youth, I found that it was a difficult matter to discuss with my parents. My perception of them was that they did not speak honestly about the camp experience.... Their words said one thing, while their hearts were holding something else deep inside." 
outcry, even from the Japanese community. Many Japanese were loath to make a fuss and prided themselves on being cooperative. ${ }^{6}$ Their pain, while perhaps not outwardly manifested, ${ }^{7}$ runs like a deep fissure through their hearts and through the soul of the Japanese-American community. ${ }^{8}$

In the legal arena, until recently, the internment's significance seemed to reduce to little more than a couple of cases, namely Korematsu v. United States ${ }^{9}$ and Hirabayashi v. United States, ${ }^{10}$ taught in constitutional law classes representing our Supreme Court's sordid past. After the terrorist attacks of September 11, 2001 (9/11), and the Bush Administration's ensuing terrorism policies, the Japanese internment has risen to the surface, not just as a reminder of the past, but as a commentary on the present and foreshadowing of the future. ${ }^{11}$ Recounting the events of the internment now is more important than

INTERNMENT OF CIVILIANS, supra note 1, at 297 (quoting Michael Yoshii).

6. One internment survivor explains,

"Society has stripped a whole group of people of confidence. We are afraid to speak out. We will try to keep the peace at any price. We will not make waves. It makes us uncomfortable to stand out. We want to blend in. We want to be middle America."

Id. at 299 (quoting Kiyo Sato-Viacrucis).

7. Dr. Tetsuden Kashima, a sociologist at the University of Washington Department of American Ethnic Studies, describes how Japanese Americans of the internment generation suffer from "“social amnesia [as] . . . a group phenomenon, in which attempts are made to suppress feelings and memories of particular moments or extended time periods . . . to cover up less than pleasant memories." Id. at 297-98 (quoting Tetsuden Kashima).

8. My family shares this negative experience with tens of thousands of others. According to the U.S. Department of the Interior, 120,313 Japanese were interned during World War II. See U.S. DEPT. OF THE INTERIOR, WRA, THE EVACUATED PEOPLE: A QUANTITATIVE DESCRIPTION 2 (1946), reprinted in WENDY NG, JAPANESE AMERICAN INTERNMENT DURING WORLD WAR II 39 (Greenwood Press 2002).

9. 323 U.S. 214 (1944) (upholding the exclusion of ethnic Japanese from the West Coast).

10. 320 U.S. 81 (1943) (upholding curfew order placed on ethnic Japanese). Both Korematsu and Hirabayashi have been widely repudiated. Justice Antonin Scalia, for example, expressed his displeasure at the Court's decision striking down a late-term abortion statute by stating, "I am optimistic enough to believe that, one day, Stenberg $v$. Carhart will be assigned its rightful place in the history of this Court's jurisprudence beside Korematsu and Dred Scott." Stenberg v. Carhart, 530 U.S. 914, 953 (2000) (Scalia, J., dissenting). Similarly, Justice Brennan called Korematsu one of "the most extreme reminders that when we allow fundamental freedoms to be sacrificed in the name of real or perceived exigency, we invariably come to regret it." Skinner v. Ry. Labor Executives' Ass'n, 489 U.S. 602, 635 (1989) (Brennan, J., dissenting). Professor Thomas Baker observes that "the Supreme Court's performance [in the internment cases] has gone down in history as one of its most craven moments." Thomas E. Baker, At War with the Constitution: A History Lesson from the Chief Justice, 14 BYU J. PUB. L. 69, 75 (1999).

11. Japanese internees fear that the lack of judicial repudiation of the internment will have negative consequences for those caught in the terror net. See Peter S. Canellos, Japanese Internees See Modern Parallels, Boston Globe, Nov. 2, 2003, at A1 ("Ever since the war on terrorism began, those who lived through the Japanese internment are shocked that . . American courts have never held that the government lacked the authority to hold people in wartime without presenting evidence."). 
ever, as memories fade and a new generation of lawyers emerges. ${ }^{12}$ I was personally surprised and saddened to hear my own students justify racial profiling to fight terrorism because, "we did it with the Japanese in World War II and Korematsu is still good law." 13

The comparisons of terrorism detentions and the internment are compelling and the subject of much scholarly discourse. ${ }^{14}$ Not since the bombing of Pearl Harbor, an event that stood as a predicate to the massive detention of Japanese Americans, had foreign agents attacked the United States on its own soil. ${ }^{15}$ Similar to the sweeping tide of antiJapanese sentiment and rhetoric after Pearl Harbor, after 9/11, there arose a national feeling of animosity directed overtly toward Arab and SouthAsian ethnic minorities or, more subtly, toward vaguely defined "terrorists," who seemed to reduce to little more than citizens of a select group of countries, subscribers to a certain set of religious beliefs, or certain ethnic groups. ${ }^{16}$ On the basis of the 9/11 attacks, the Bush

12. Scholars note that the Bush Administration's post-9/11 policies have "occurred despite the government's official acknowledgement of the injustice in the wholesale incarceration of JapaneseAmericans. Sadly, the Bush Administration has seemingly ignored this history." Susan Kiyomi Serrano \& Dale Minami, Korematsu v. United States: A "Constant Caution" in a Time of Crisis, 10 ASIAN L.J. 37, 45 (2003).

13. Similar statements occurred both in my criminal procedure class and a colleague's class. See also Chris K. Iijima, Shooting Justice Jackson's "Loaded Weapon" at Ysar Hamdi: Judicial Abdication at the Convergence of Korematsu and McCarthy, 54 SYRACUSE L. REV. 109, 132 n.132 (2004) (noting "the recent sentiment that has attempted to 'sanitize' the Japanese American internment"). Alfred Yen observes that Korematsu's legacy is not necessarily one of total disrepute and shame. Rather, he asserts that the internment was "praised with faint damnation" by Chief Justice Rehnquist and that the Chief Justice "seem[ed] curiously untroubled by either internment or the Korematsu majority." Alfred C. Yen, Praising with Faint Damnation-The Troubling Rehabilitation of Korematsu, 40 B.C. L. REV. 1, 2-3 (1998). See also Jerry Kang, Denying Prejudice: Internment, Redress and Denial, 51 UCLA L. REV. 933, 1001 (2004) (stating that Rehnquist's "strategy ... is the return of the Korematsu mindset"); Eric Yamamoto et al., American Racial Justice on Trial-Again: African American Reparations, Human Rights, and the War on Terror, 101 MICH. L. REV. 1269, 1277-78 n.58 (2003) (noting "Chief Justice Rehnquist's approval of the original Korematsu decision ... as part of his philosophy of almost total judicial deference to the executive branch ... during war").

14. Since 9/11, a number of legal scholars have revived the Korematsu discourse. See, e.g., Iijima, supra note 13; Serrano \& Minami, supra note 12, at 40; Mark Tushnet, Defending Korematsu: Reflections on Civil Liberties in Wartime, 2003 WIS. L. REV. 273; Elbert Lin, Case Comment, Korematsu Continued, 112 YALE L.J. 1911 (2003). The internment was also revisited in the popular press. See, e.g., Mike Boehm, Repeating the History, L.A. TiMES, Feb. 20, 2004, at E2; Canellos, supra note 11; Angie Chuang, Embracing the Future, Remembering the Past, OREGONIAN, Sept. 12, 2003, at C2; Annie Nakao, Haunting Echoes of Japanese Internment, S.F. CHRON., Feb. 18, 2003, at D8; Aretha Williams, Cancer of Hatred and Intolerance Alive on American Soil, SAN ANTONIO EXPRESS-NEWS, May 31, 2004, at 11E.

15. See Eric L. Muller, Inference or Impact? Racial Profiling and the Internment's True Legacy, 1 OHIO ST. J. CRIM. L. 103, 106 (2003) ("Pearl Harbor is, after all, the clearest and most recent analogue to the attacks of September 11.").

16. See Daniel M. Filler, Terrorism, Panic, and Pedophilia, 10 VA. J. Soc. PoL'Y \& L. 345 , 367 (2003) ("Within a week of the attack, the Council on American-Islamic Relations reported 
Administration initiated two regime-changing wars, detained tens of thousands of people, ${ }^{17}$ and even took U.S. citizens into military custody. ${ }^{18}$ Civil libertarians criticize the policies as exemplifying governmental overreaching that deprives individuals of their liberty without reasonable basis or process. ${ }^{19}$ In response, the Administration and its supporters have developed discursive mechanisms for quelling public concern. The Administration has successfully engineered a prevailing ideology of executive deference. ${ }^{20}$ Closely related are propagandized notions of patriotism that equate a defense of civil liberties with treason. For example, Attorney General Ashcroft responded to criticism of Department of Justice overreaching by stating,

[T]o those who scare peace-loving people with phantoms of lost liberty; my message is this: Your tactics only aid terrorists - for they erode our national unity and diminish our resolve. They give ammunition to America's enemies, and pause to America's friends. They encourage people of good will to remain silent in the face of evil. $^{21}$

hundreds of cases of Muslims being threatened, harassed, and attacked. A vigilante killed an Arizona Sikh man he mistook for a Muslim.”).

17. It is extremely difficult to determine the number of detainees held in U.S. custody here and abroad, not only because the Pentagon refuses to release such information, but also because the situation is volatile. As of the writing of this Article, the International Commission of the Red Cross estimated there to be at least 5000 detainees in Iraq, 550 in Afghanistan, and between 550 and 600 in Guantanamo. See International Convention of the Red Cross, http://www.icrc.org/eng (follow "ICRC detention visits" hyperlink; then follow "US detention related to the events of 11 September 2001" hyperlink) (last visited Feb. 1, 2006); see also Deborah PeArlstein, Ending SeCret Detentions 12 (Michael Posner, ed., Human Rights First, 2004), available at http://www. humanrightsfirst.org/US_law/PDF/EndingSecretDetentions_web.pdf, at 12 ("In early January 2004, the total number of detainees [in Iraq] was approximately $12,000 \ldots .$. "). In addition, there are detainees held outside these regions both known and unknown to international officials. See CHRIS MACKey \& Greg Miller, The Interrogators: Inside the Secret War Against Al QAeda 467 (2004) (stating that the United States "[is] said to be holding as many as ten thousand people" at various detention facilities worldwide); see also U.S. Counts 108 Deaths in Custody in Iraq, Afghanistan, L.A. TIMES, Mar. 17, 2005, at A7 ("About 65,000 prisoners have been taken during the U.S.-led wars, most of whom have been freed.").

18. See Hamdi v. Rumsfeld, 542 U.S. 507 (2004) (allowing U.S. citizen to be held as enemy combatant); Rumsfeld v. Padilla, 542 U.S. 426 (2004) (finding lack of jurisdiction over detainee's habeas petition).

19. See Iijima, supra note 13; Serrano \& Minami, supra note 12.

20. See, e.g., Ctr. for Nat'l Sec. Studies v. U.S. Dep’t of Justice, 331 F.3d 918, 927 (D.C. Cir. 2003) ("We have consistently reiterated the principle of deference to the executive ... when national security concerns are implicated.").

21. DOJ Oversight: Preserving our Freedoms while Defending against Terrorism: Hearing Before the Senate Comm. on the Judiciary, 107th Cong. (2001) (testimony of Attorney General John Ashcroft), available at $\mathrm{http} / /$ judiciary.senate.gov/testimony.cfm?id=121\&wit_id=42. 
Critics of the government also censure its policies by arguing that President Bush has stepped dangerously close to the line crossed by the Roosevelt Administration in enacting internment policies. ${ }^{22}$ Bush defenders are quick to assert that currently there has been no systematic detention of ethnic Arab-American citizens. $^{23}$ Of course, civil libertarians respond that the few citizen detentions, combined with the massive detentions of noncitizens, represent as big, or nearly as big, a humanitarian crisis as the large-scale detention of citizens. ${ }^{24}$ Moreover, Administration defenders assert that Bush's policies are far more progressive than those regarding the Japanese in World War II. ${ }^{25}$ This assertion has found surprising backing from liberal law professors who claim that the current policies manifest civil libertarian evolution from World War II. ${ }^{26}$ These scholars have set forth what I term "distancing arguments," positing simply that American society and government have progressed from the time of the Japanese internment, such that an abuse of that type and/or magnitude is unlikely to occur again. ${ }^{27}$

Former internees, like Holocaust survivors, hope that prolonging the collective memory of the events will operate to ensure that such practices are never again repeated. ${ }^{28}$ One internment survivor asked, "“how could

22. See Serrano \& Minami, supra note 12 .

23. However, hundreds of Arab noncitizens have been detained on U.S. soil as have thousands abroad. Bush defenders might respond that aliens are not entitled to the same rights as citizens, relying on cases such as United States v. Verdugo-Urquidez, 494 U.S. 259, 269 (1990), Leng May Ma v. Barber, 357 U.S. 185, 190 (1958), and Kaplan v. Tod, 267 U.S. 228, 230 (1925). One could argue, however, that these cases represented serious blows to civil rights. See generally Natsu Taylor Saito, For "Our" Security: Who is an "American" and What is Protected by Enhanced Law Enforcement and Intelligence Powers?, 2 SeAtTlE J. Soc. Just. 23 (2003-04) (examining the negative impact of enlarged law enforcement powers over noncitizens).

24. They argue that the greatest harm is not attendant to citizenship status, but rather to the deprivation of individual liberty without reasonable basis or process-especially when that deprivation is based on race or ethnicity. The Supreme Court itself has recognized the harms of unjust deprivation of noncitizens' liberty. See Zadvydas v. Davis, 533 U.S. 678, 690 (2001) (holding that statute permitting indefinite detention of certain aliens violated due process).

25. Regarding post-9/11 detention of Arab immigrants, Justice Department officials stated, "Any comparison to the Japanese-American internment ... is far off base. "All of the actions we have taken have been mindful of the problems in the past." Curt Anderson, Courts Back Feds in Legal War on Terror, ASSOCIATED PRESS, July 26, 2003, available at http://mailman1.u. washington.edu/pipermail/hrnetnews/2003-June/005821.html (quoting Justice Department spokeswoman Barbara Comstock).

26. Professor Eric Muller states, for example, "I do not think it helpful or accurate to say, as David Cole does, that these sorts of comparatively minor burdens [on Arabs] reflect 'the rationale used to intern 110,000 persons of Japanese ancestry during World War II." Muller, supra note 15, at 123 (quoting David Cole, Enemy Aliens, 54 STAN. L. REV. 953, 976 (2002)).

27. E.g., Tushnet, supra note 14, at 296.

28. When Fred Korematsu was awarded the Medal of Freedom in 1998, he remarked, "We should be vigilant to make sure this will never happen again." Brief for Fred Korematsu et al. as 
this ever happen in a democracy? How could this happen to American citizens without the benefit of a trial?'... 'Everyone that was evacuated, we had in our minds that it shouldn't happen to anybody ever again." ${ }^{29}$ The reminder of atrocities from the past serves as a check on present and future government power. ${ }^{30}$ The rhetoric of conservatives and scholars who extol society's progress undercuts the persuasive force of this reminder. Conservatives often employ distancing arguments to separate current controversial rights infringements from past abuses now considered unquestionably oppressive. ${ }^{31}$ Especially in times of emergency, the idiom of progress is engaged to silence comparisons to past atrocities and allay fears of government overreaching. ${ }^{32}$

This Article examines through a critical lens the claim that the United States' policy toward ethnic minorities during times of distress has progressed since the time of World War II, rendering internment comparisons irrelevant. It seeks to answer the important question of whether our nation has learned history's lessons. Professor Thomas Baker queries,

$\lceil\mathrm{H}\rceil$ istory tells this story: In past wars the Executive Branch has prosecuted the war abroad and has had its way with civil liberties at home, while the Supreme Court has merely stood by, for the most part, perhaps disapproving the most grievous and least justified domestic transgressions but even then usually only after-the-fact.

Have things changed? Is America different today? Does the Constitution mean something different? Do these same powers attend the newly declared "war on terrorism"?

Amici Curiae Supporting Respondents at 2, Rumsfeld v. Padilla, 542 U.S. 426 (2004) (No. 031027).

29. Collins, supra note 3 (quoting Mari Michener, wife of novelist James Michener and a former internee). Another internment survivor remarked, "It is important to ensure that this violation of human rights is not repeated'... 'for any race, any religion, any group at any time."” Chuang, supra note 14 (quoting Fred Hansen).

30. Jerry Fowler, director of the U.S. Holocaust Memorial Museum observes, "A common response to the Holocaust is 'never again.' The reality around the globe is that we've fallen woefully short of that goal." Gary Soulsman, A Mandate and a Mission: Keep Truth Alive, THE NEwS JOURNAL, April 15, 2001, available at http://www.delawareonline.com/newsjournal/local/ 2001/holocaust/children side2.html.

31. See infra notes $81-88$ and accompanying text (discussing distancing arguments in gender and race context).

32. Indeed, during World War II, Justice Jackson observed optimistically, "Modern American law has come a long way since the time when outbreak of war made every enemy national an outlaw, subject to both public and private slaughter, cruelty and plunder." Johnson v. Eisentrager, 339 U.S. 763, 768-69 (1950). At the time, however, not only did the government imprison enemy nationals, it also imprisoned its own citizenry.

33. Thomas E. Baker, At War with Civil Rights and Civil Liberties, 34 CASE W. RES. J. INT'L L. 
In answering this question, the Article compares and contrasts the law of the Japanese internment with the law pertaining to the current terrorism detentions. Specifically, the Article creates a framework in which the relevant Supreme Court cases can be evaluated to determine whether the United States, as defined by its governing laws, has in fact evolved since the time of Korematsu. Part II of the Article discusses post-9/11 invocations of the internment to criticize the current use of state power and the distancing arguments forged in response. Part II also proposes that the validity of the distancing arguments can be evaluated through a comparative legal assessment. Part III of the Article sets forth the relevant internment and terrorism detention cases as a preface to a methodological comparison of the laws. Part IV deconstructs and analyzes the law of war, as articulated by relevant cases, with a particular emphasis on the jurisprudential choices made by the Court in the internment and terrorism cases. By comparing these choices, the Article concludes that although in Hamdi v. Rumsfeld ${ }^{34}$ the Supreme Court did close some of the avenues toward oppressive governmental activity present in the internment cases, the Court nonetheless left several avenues open and even expanded them. Consequently, the cautions of Korematsu remain relevant despite fairly widespread belief that the Hamdi decision manifested civil libertarian progress. ${ }^{35}$

\section{THE REEMERGENCE OF THE INTERNMENT, DISTANCING ARGUMENTS, AND THE ROLE OF LAW AS ARBITER}

\section{A. The Internment Reborn}

As stated above, many legal scholars invoke the Japanese internment to caution the Bush Administration of the dangers of governmental

219, 220 (2002). See also Oren Gross, Chaos and Rules: Should Responses to Violent Crises Always Be Constitutional?, 112 YALE L.J. 1011, 1019 (2003) ("Experience shows that when grave national crises are upon us, democratic nations tend to race to the bottom as far as the protection of human rights and civil liberties, indeed of basic and fundamental legal principles, is concerned.").

34. 542 U.S. 507 (2004).

35. The Washington Post declared in a headline, "Supreme Court Backs Civil Liberties in Terror Cases," and quoted Michael Ratner of the Center for Constitutional Rights as saying, "This is a major victory for the rule of law and affirms the right of every person, citizen or noncitizen, detained by the United States to test the legality of his or her detention in a U.S. court." Fred Barbash, Supreme Court Backs Civil Liberties in Terror Cases, WASHINGTONPOST.COM, June 28, 2004, http://www.washingtonpost.com/wp-dyn/articles/A11657-2004Jun28.html (quoting Michael Ratner). By contrast, members of the Bush Administration characterized the case as upholding executive wartime power. Spokesman Mark Corallo said the Administration was pleased the Court " "upheld the authority of the President as Commander-in-Chief of the armed forces to detain enemy combatants, including U.S. citizens."” Id. (quoting Mark Corallo). 
overreaching. ${ }^{36}$ Professor Eric Muller describes the use of the Japanese internment as a rhetorical tool to criticize Bush Administration antiterrorism policies:

Critics charged that by pursuing investigative and enforcement policies that took national origin into account, the government was making not only bad new rules but a bad old mistake - the mistake that led to the incarceration of 120,000 people of Japanese ancestry, or "Nikkei," during World War II. and the iudicial approval of much of that program in Korematsu v. United States.

Examining the legal literature, there are two different but related areas in which the Japanese internment has reemerged as a tool of modern critique: racial profiling of terrorists and military detention without criminal process.

Scholars have drawn upon the internment to caution against the use of race-based terrorism policies, in the face of the increasing acceptance and encouragement of such policies by the American public. Experts and news organizations have documented a resurgence of racial and ethnic profiling during the War on Terror. ${ }^{38}$ Professor David Cole observes that before $9 / 11$, racial profiling was more taboo than applauded, both legally and in the social consciousness. ${ }^{39}$ Legally, racial profiling had been the subject of high-profile civil law suits, ${ }^{40}$ settlements, ${ }^{41}$ and the most exacting standard of governmental

36. See sources cited supra note 14; see also Charles I. Lugosi, Rule of Law or Rule By Law: The Detention of Yaser Hamdi, 30 AM. J. CRIM. L. 225, 278 (2003) (arguing that preserving the rule of law is important in wartime); Natsu Taylor Saito, Will Force Trump Legality after September 11? American Jurisprudence Confronts the Rule of Law, 17 GEO. IMMIGR. L.J. 1, 60-61 (2002) (analyzing how to effectively oppose unchecked political power in wartime); Serrano \& Minami, supra note 12, at 40 (arguing that preserving the rule of law is important in wartime).

37. Muller, supra note 15 , at 104-05.

38. See Amnesty international, threat and Humiliation: Racial Profiling, DOMESTIC Security, AND HuMAN Rights IN THE UNiTED STATES vi (2004), available at http://www.amnestyusa.org/racial_profiling/report/rp_report.pdf ("Racial profiling of citizens and visitors of Middle Eastern and South Asian descent, and others who appear to be from these areas or members of the Muslim and Sikh faiths, has substantially increased since September 11, 2001.").

39. Cole observes, "Before September 11, about 80 percent of the American public considered racial profiling wrong. State legislatures, local police departments, and the President had condemned the practice and ordered data collection on the racial patterns of stops and searches." Cole, supra note 26, at 974.

40. John M. Broder, California Ending Use of Minor Traffic Stops as Search Pretext, N.Y. TIMES, Feb. 28, 2003, at A18 (discussing high-profile lawsuits against police for racial profiling); Tina Kelley, Police Dept. Settles Race Suit, N.Y. Times, Sept. 19, 2003, at B9 (same).

41. See Michael Powell, N.Y. Settles Lawsuit On Racial Profiling; Police Must Report Frisk Cases, WASH. Post, Sept. 20, 2003, at A3 ("The police department ... will pay a total of $\$ 167,500$ to the 10 black men who filed the federal civil rights lawsuit."); Racial Profiling Cases Settled, N.Y. 
justification, strict scrutiny. ${ }^{42}$ Widespread media reporting on "driving while black," ${ }^{43}$ and race-based abuses committed by police officers ${ }^{44}$ made many wary of law enforcement's use of racial profiling as even an unofficial police tactic. After 9/11, the government embraced an overt and extensive policy of racial decision making. The government began to use its broad immigration powers to selectively detain immigrants of Arab nationality and ethnicity. ${ }^{45}$ In addition, ethnic Arabs were systematically singled out for police investigation and detention. ${ }^{46}$ Unlike the above-mentioned aversion to racial profiling by police, after $9 / 11$, the public generally accepted the propriety of race-based measures in the name of terrorism prevention. ${ }^{47}$ Even African Americans and

TiMES, Jan. 9, 2003, at B7 ("The state has paid $\$ 575,000$ to settle lawsuits filed by 12 motorists who allege they were subjected to racially profiling by state troopers.").

42. Ironically, Korematsu set up the rigid standard of justification for race-based policies Korematsu, 323 U.S. 214, 220 (1944). Strict scrutiny requires that the race-based policy be narrowly tailored to further a compelling state interest. The Korematsu Court, however, found that the Japanese internment met this test. $I d$ at 223.

43. See, e.g., David Kocieniewski \& Robert Hanley, An Inside Story of Racial Bias and Denial: New Jersey Files Reveal Drama Behind Profiling, N.Y. TIMES, Dec. 3, 2000, § 1 (Metro), at 53.

44. See, e.g., Richard Fausset et al., Police Beating Touches Old Wounds, L.A. TIMES, June 28, 2004, at B1 (discussing recent race-based beating).

45. The 1996 amendments to the Immigration and Naturalization Act set forth special procedures governing the removal of aliens suspected of terrorist activity. Specifically, the amendments authorized the Attorney General to "retain" in custody aliens suspected of terrorism. Permanent residents could contest the detention, but they bore the burden to prove that they met conditions for release. Antiterrorism and Effective Death Penalty Act of 1996, Pub. L. No. 104-132, 110 Stat. 1214. Subsequently, the definition of "terrorist activity" was dramatically expanded by the Uniting and Strengthening America by Providing Tools Required to Intercept and Obstruct Terrorism Act of 2001 (USA PATRIOT Act), Pub. L. No. 107-56, 115 Stat. 272 (2001).

46. Professor Natsu Taylor Saito remarks,

Noncitizens, both temporary visitors and permanent residents, have been subjected to a variety of harsh measures, including the expedition of thousands of deportations; the "disappearance" and detention of at least 1,200 people; interrogations in the form of "voluntary interviews" with officials from the Federal Bureau of Investigation (FBI) and Immigration and Naturalization Service (INS) .... .

Most of these measures have targeted men from Middle Eastern or predominantly Muslim countries.... [T] he government's actions are largely immune from constitutional challenge thanks to a long history of Supreme Court cases stating that the "political branches" of government, i.e., the executive and the legislature, have essentially unfettered power with respect to immigration.

Saito, supra note 23, at 25 (footnotes omitted).

47. See Cole, supra note 26, at 974 (noting that sixty percent of Americans favor ethnic profiling of Arabs and Muslims). Peter N. Kirsanow, a Bush appointee to the Commission on Civil Rights, disturbingly stated that "If there's another terrorist attack and if it's from a certain ethnic community or certain ethnicities that the terrorists are from, you can forget civil rights in this country. . . . I think we will have a return to Korematsu." He added, "Not too many people will be crying in their beer if there are more detentions, more stops and more profiling." Andrew Chow, Landmark APA Legal Team Demands Commissioner's Ouster, ASIANWEEK, Aug. 15, 2002, http://www.asianweek.com/2002_08_09/news_korematsu.html (quoting Peter N. Kirsanow). 
Latinas tended to favor ethnic and racial profiling so long as directed against "terrorists." "48

In the face of such widespread acceptance of racial profiling in the name of national security, commentators began to appeal to imagery of the internment to counsel the government and public of the perils of racial profiling. They employed the internment to emphasize the evil of using race as a basis for rights deprivations. ${ }^{49}$ Professor Deborah Ramirez, for example, stated, "The public support for racial profiling as a method for preventing acts of espionage or terrorism is reminiscent of sentiment expressed in this country prior to the internment of JapaneseAmericans residing on the West Coast during World War II."50 The comparison of current views of Arab Americans with historical views of Japanese Americans stands as a caution to society not to fall prey to the pernicious social psychology that predicated Japanese internment.

Moreover, reminders of the Japanese internment are meant to evoke feelings of distaste and guilt in the general public regarding race-based policies. The internment has come to represent one of history's most serious incidents of racial oppression, exceeded perhaps only by genocide. ${ }^{51}$ Recalling the internment thus causes unease about the use of race in governmental decision making. Historians, lawyers, and laymen alike look with utter disdain upon General John L. DeWitt's ${ }^{52}$ racist

48. According to some news organizations, after 9/11, African Americans, as a group, were most likely to support racial profiling to combat terrorism. See Catherine Donaldson Evans, Terror Probe Changes Face of Racial Profiling Debate, Fox News, Oct. 1, 2001, http://www.foxnews. com/story/0,2933,35521,00.html ("A recent Gallup poll found that African-Americans are more likely than other racial and ethnic groups to support profiling and tight airport security checks for Arabs and Arab-Americans since the Sept. 11 disaster.").

49. David Cole observed, "The argument that we cannot afford to rely on something other than racial or ethnic proxies for suspicion, after all, is precisely the rationale used to intern 110,000 persons of Japanese ancestry during World War II.” Cole, supra note 26, at 976.

50. Deborah A. Ramirez et al., Defining Racial Profiling in a Post-September 11 World, 40 AM. CRIM. L. REV. 1195, 1201 (2003).

51. See Joseph Onek, Critique 19 J.L. \& RELIGION 85, 85 (2003-04) ("World War II saw one of the greatest stains on American democracy and certainly one of the greatest overreactions, the internment of Japanese Americans . . . ."); Michael Stokes Paulsen, The Constitution of Necessity, 79 NOTRE DAME L. REV. 1257, 1294 (2004) ("The World War II internment of Japanese-Americans was a tragic injustice ... perpetrated by all three branches of the national government."); Juan R. Torruella, On the Slippery Slopes of Afghanistan: Military Commissions and the Exercise of Presidential Power, 4 U. PA. J. ConsT. L. 648, 668-69 (2002) ("[T] one of its least glorious moments, succumbing perhaps to the war hysteria of the moment, by approving the internment of U.S. citizens of Japanese descent."); Stephen I. Vladeck, Policy Comment, A Small Problem of Precedent: 18 U.S.C. 4001(a) and the Detention of United States Citizen "Enemy Combatants," 112 YALE L.J. 961, 968 (2003) (calling the Japanese internment "one of the darker moments in the history of the U.S. government's treatment of its own citizens").

52. General DeWitt was a U.S. Army Commander of the Fourth Army headquarters at the Presidio in San Francisco. In his office, he oversaw the internment of more than 115,000 Japanese. In addition, General DeWitt testified in front of Congress and authored a report in support of the 
sentiment that "a Jap is a Jap," 53 in light of the terrible events that sentiment brought about. ${ }^{54}$ This feeling of aversion can then effectively transfer to some of the Anti-Arab rhetoric after 9/11, like Congressman John Cooksey's statement that the police would be justified in stopping any person with "a diaper on his head and a fan belt wrapped around the diaper." $" 55$

Commentators further bring up the Japanese internment to illustrate the dangerous flaw in race-based reasoning, arguing that unfounded or even slightly correlative assumptions about race not only lead to grave civil libertarian injuries, but also undermine security by focusing government efforts on inaccurate dangerousness predictors. ${ }^{56}$ Professor David Cole states, "we have targeted immigrants based on their Arab identity, and in doing so have fallen prey to the same kind of ethnic stereotyping that characterized the fundamental error of the Japanese

internment. John L. DeWitt, OfFice of the COMmanding General FinAl Report: JaPANESE EVACUATION FROM THE WEST COAST (1942).

53. The full text of this statement, which appeared in Hearst's San Francisco News on April 13, 1943 , reads,

"I don't want any Jap back on the Coast.... There is no way to determine their loyalty .... It makes no difference whether the Japanese is theoretically a citizen-he is still a Japanese. Giving him a piece of paper won't change him. . . I don't care what they do with the Japs as long as they don't send them back here. A Jap is a Jap."

Jerry Kang, supra note 13, at 987 (quoting H.R. REP. No. 1911, at 13-14 (1942) (Tolan Committee Report)). DeWitt also stated,

You needn't worry about the Italians at all except in certain cases. Also, the same for the Germans except in individual cases. But we must worry about the Japanese all the time until he is wiped off the map. Sabotage and espionage will make problems as long as he is allowed in this area-problems which I don't want to have to worry about.

Investigation of Congested Areas: Hearings Before the Subcomm. of the H. Comm. On Naval Affairs, 78th Cong. 740 (1943) (testimony of Lieutenant General John L. DeWitt, Commanding General of Western Defense Command).

54. Professor Keith Aoki, however, cautions us not to forget the institutional foundations of the internment. He criticizes "various accounts of the internment of Japanese Americans . . assigning blame to renegade 'bad actors' such as Lt. DeWitt or persons in the War Department who deliberately withheld, or lied about, information regarding the nature of the threat posed by Japanese Americans on the West Coast." Keith Aoki, No Right to Own?: The Early Twentieth Century "Alien Land Laws" as a Prelude to Internment, 40 B.C. L. REV. 37, 69 (1998).

55. John LaPlante, La. Congressman's Comments on Racial Profiling Surprise Some, THE Advocate (Baton Rouge), Sept. 20, 2001, at 1B.

56. The logical error is that the government substitutes race for more accurate and individualized determinations of disloyalty or criminality. Even if it were true that "all terrorists are Arab," which is itself a ridiculous statement (even Al Qaeda includes Africans, Asians, and Caucasians) it does not logically follow that "all Arabs are terrorists." This, in turn, makes concentrating on race a poor substitute for concentrating on more relevant factors. Race is thus a distraction, and racial policies render the nation less safe. Moreover, making any correlative link between race and terrorism or criminality is scientifically difficult given selective enforcement and prosecution. Deborah Ramirez adds, "The main limitation is that [racial profiling] data focus[es] on arrests and convictions, rather than on the actual incidence of criminal conduct, and these numbers cannot account for law enforcement or prosecutorial discretion." Ramirez, supra note 50, at 1211. 
internment." 57 The argument is that by using the broad category of ethnicity as a proxy for terrorism, the government is committing the same logical error the Roosevelt Administration committed by using ethnicity as a proxy for disloyalty. ${ }^{58}$

In addition to drawing upon the internment as a persuasive tool against racial profiling, scholars invoke the internment to criticize the government's imposition of detention without process. ${ }^{59}$ They understand Korematsu to represent a principle of detention without credible basis or appropriate judicial oversight. ${ }^{60}$ Professor Chris Iijima argues that one of the most disturbing aspects of the Japanese internment is that persons were stripped of liberty, not on the basis of any specific finding of individual dangerousness or disloyalty, but rather on the mere basis of unsubstantiated "military necessity." "61 Professor Dean Hashimoto opines that the "central lesson we learn from Korematsu appears to be that there is an important role for judicial review of substantive decisions by military authorities" and that "the Court should recognize that Korematsu stands for the principle of judicial abstention." ${ }^{62}$ Inherent in such analyses of Korematsu are two criticisms: first, that the executive branch deprived persons of liberty without process and without proper basis for denying process; ${ }^{63}$ and second, that

57. Cole, supra note 26, at 994

58. See Ramirez, supra note 50, at 1211 (discussing the problems with using race as justification to conduct a traffic stop). David Cole observes, "In arguments that eerily foreshadow the 'sleeper' theories advanced about Al Qaeda today, government officials argued that the fact that Japanese aliens and citizens living among us had taken no subversive action yet only underscored how dangerous they were." Cole, supra note 26, at 992.

59. See, e.g., Cole, supra note 26, at 989-94; David Cole, The New McCarthyism: Repeating History in the War on Terrorism, 38 HARV. C.R.-C.L. L. REV. 1, 18 (2003); Muller, supra note 15, at 119 (all referencing the Japanese internment of World War II).

60. See Tania Cruz, Judicial Scrutiny of National Security: Executive Restrictions of Civil Liberties When "Fears and Prejudices are Aroused," 2 SEATtLE J. Soc. Just. 129, 134 (2003) ("The [Korematsu] Court's deference, despite its pronouncement of heightened scrutiny, has been sharply criticized as subverting civil liberties to falsified claims of national security.").

61. Iijima, supra note 13, at 123-25. See also Korematsu v. United States, 323 U.S. 214, 219 (1944) (relying on "the finding of the military authorities that it was impossible to bring about an immediate segregation of the disloyal from the loyal").

62. Dean M. Hashimoto, The Legacy of Korematsu v. United States: A Dangerous Narrative Retold, 4 ASIAN PAC. AM. L.J. 72, 124-25 (1996).

63. Justice Murphy noted,

The main reasons relied upon by those responsible for the forced evacuation, therefore, do not prove a reasonable relation between the group characteristics of Japanese Americans and the dangers of invasion, sabotage and espionage. The reasons appear, instead, to be largely an accumulation of much of the misinformation, half-truths and insinuations that for years have been directed against Japanese Americans. 
the Supreme Court neglected its duty to assess the factual adequacy of purported reasons for the detention scheme. ${ }^{64}$

The Roosevelt Administration relied on the military judgment that there were "disloyal" members of the Japanese-American community ${ }^{65}$ to conclude that it was necessary to detain persons without regard to basic due process. ${ }^{66}$ Critics argue that the evidence underlying the assumption that Japanese presence on the West Coast represented a danger was false, spurious, and biased. ${ }^{67}$ They further assert that even if the government's claims of danger were slightly credible, some individual process, such as individual loyalty hearings, ${ }^{68}$ could have been afforded to the Japanese, rather than process-less detention en masse. ${ }^{69}$

64. See Christopher N. May, In the NAme of WAR: Judicial Review And the WaR POWERS SINCE 1918, at 261 (1989) (describing the Japanese internment cases as "[t]he most egregious example of abdication in the form of ritualistic approval [that] occurred during World War II"); Cruz, supra note 60, at 171:

Today, the judiciary needs to be the final arbiter and protector of fundamental liberties of citizens and noncitizens alike. If it abdicates this role, as it did in Korematsu, then the very democratic foundation of the country is at risk. If the executive's expansive authority over American civil liberties is not checked, the excesses of today will haunt us tomorrow.

65. See Korematsu, 323 U.S. at 218 (citing military opinion that "there were disloyal members of that population, whose number and strength could not be precisely and quickly ascertained"” (quoting Hirabayashi v. United States, 320 U.S. 81, 99 (1943))).

66. The Court characterized exclusion as the result of a military belief "that in a critical hour [disloyal] persons could not readily be isolated and separately dealt with, and constituted a menace to the national defense and safety, which demanded that prompt and adequate measures be taken to guard against it." Id. Recognizing the "hardship" on the Japanese, the Court explained,

$[\mathrm{H}]$ ardships are part of war, and war is an aggregation of hardships. All citizens alike,

both in and out of uniform, feel the impact of war in greater or lesser measure.

Citizenship has its responsibilities as well as its privileges, and in time of war the burden

is always heavier. Id. at 219 .

67. See Yamamoto et al., supra note 13, at 1274-75 ("[T]he key West Coast military commander ordering the internment based his decisions on invidious racial stereotypes about inscrutable, inherently disloyal Japanese-Americans and on falsified evidence of espionage and sabotage ....").

68. Justice Murphy criticized the Court's refusal to require some procedure:

It seems incredible that . . . it would have been impossible to hold loyalty hearings for the mere 112,000 persons involved — or at least for the 70,000 American citizens - especially when a large part of this number represented children and elderly men and women. Any inconvenience that may have accompanied an attempt to conform to procedural due process cannot be said to justify violations of constitutional rights of individuals.

Korematsu, 323 U.S. at 241-42 (Murphy, J., dissenting).

69. Gil Gott notes that DeWitt's reasoning for denying individual process "boiled down to a racist assumption that there was no way to separate the 'sheep from the goats' because the Japanese were such a 'tightly-knit racial group."' Gil Gott, A Tale of New Precedents: Japanese American Internment as Foreign Affairs Law, 40 B.C. L. REV. 179, 234 (1998) (quoting PETER IRONS, JUSTICE AT WAR: THE STORY OF THE JAPANESE AMERICAN INTERNMENT CASES 208 (1983)). 
Scholars draw upon similar arguments to criticize the detentions of citizen Yaser Hamdi, citizen Jose Padilla, and the Guantanamo prisoners. Experts maintain that, like the Japanese, these individuals have been subject to incarceration with little or no process, without compelling reasons for denying process. $^{70}$ Critics reject the government's contentions that civilian criminal courts are ill equipped to handle terrorism cases ${ }^{71}$ and that detainees are not entitled to the protections of the Geneva Convention. ${ }^{72}$ Furthermore, scholars are highly critical of the process afforded to individuals who wish to challenge the detention. Although the Supreme Court ruled that Yaser Hamdi was entitled to a low-level evidentiary hearing to contest his status as an unlawful combatant, ${ }^{73}$ that process falls far short of even a pretrial detention hearing in criminal court. ${ }^{74}$ In addition, while Supreme Court has stated

70. See, e.g., Lugosi, supra note 36, at 254 ("At least in principle, there is no difference between the role of the Mobbs Declarations in Hamdi and Padilla and the order of General DeWitt justifying the indefinite detention of citizens like Korematsu in concentration camps during World War Two.").

71. For example, Professor Jonathan Turley rejects the argument that criminal courts cannot safely accommodate terrorism prosecutions:

[T]his general argument ignores the long experience of federal courts in handling national security cases, including terrorist cases involving Al Qaeda operatives. Congress has already addressed the dangers of the release of national security information in such trials with the enactment of the Classified Information Procedures Act ("CIPA") in 1980.

Under CIPA, the government is able to apply many of the same restrictions under federal law as it would in a military tribunal, including non-public hearings, ex parte and in camera reviews, and redacted evidence.

Jonathan Turley, Trials and Tribulations: The Antithetical Elements of Military Governance in a Madisonian Democracy, 70 GEO. WASH. L. REV. 649, 745-46 (2002).

72. Article 4 of the Geneva Convention sets forth the categories of persons captured who may be considered prisoners of war, which include those "who on the approach of the enemy spontaneously take up arms to resist the invading forces, without having had time to form themselves into regular armed units." Geneva Convention Relative to the Treatment of Prisoners of War, art. 4, Oct. 21, 1950, 75 U.N.T.S. 135. One can see ample grounds for detainees who fought openly against the invading U.S. forces to claim that they are prisoners of war. The Convention further states as follows: "Should any doubt arise as to whether persons ... belong to any of the categories enumerated in Article 4, such persons shall enjoy the protection of the present Convention until such time as their status has been determined by a competent tribunal." Id. at art. 5. The government's position that it can freely categorize detainees as unlawful combatants has garnered much criticism. See Manooher Mofidi \& Amy E. Eckert, "Unlawful Combatants" or "Prisoners of War:" The Law and Politics of Labels, 36 CORNELL INT'L L.J. 59, 60 (2003) ("Interpolating unrecognized exceptions into the contours of prisoner of war status, particularly when done by the world's leading military superpower, undermines the Geneva Conventions as a whole."). The International Red Cross is unwavering in its position that Taliban detainees are prisoners of war. Red Cross: Detainees "are POWs," CNN.COM, Feb. 8, 2002, http://www.cnn.com/2002/ WORLD/europe/02/08/ret.cuba.redcross.

73. Hamdi v. Rumsfeld, 542 U.S. 507, 601-02 (2004). See infra Part III. D (discussing the low burden on the government to justify continued detention).

74. Under the Federal Bail Reform Act, the government must prove by clear and convincing evidence at a contested hearing "that no condition or combination of conditions will reasonably 
that U.S. courts have jurisdiction over Guantanamo detainees' habeas corpus claims, ${ }^{75}$ the government continues to urge district courts to abstain from hearing such petitions. ${ }^{76}$ Moreover, the D.C. Circuit recently ruled that President Bush's treatment of the Guantanamo detainees was perfectly legal. ${ }^{77}$ Internment invocations are accordingly used to emphasize grave harm of process-less incarceration in the name of national security. Critics warn that "some in government are seeking to resurrect ... Korematsu to justify the Bush Administration's presentday national security curtailment of civil liberties."

Thus, the Japanese internment has become a dialectical tool to counsel against race-based reasoning and hasty deprivations of liberty in the name of security. Critics hope that by drawing upon the internment, members of the Bush Administration and political right will be moved to tone down rights-violating policies in an effort to avoid creating a legacy of harm and abuse. ${ }^{79}$ Professor Michael Ratner cautions that the Bush Administration, like the Roosevelt Administration, may very well face future reprobation and a legacy of stigma based on its post-9/11 policies:

[S]omeday in the future, we will look back on the actions of the Bush Administration and see them as we now view the actions of the Roosevelt administration in establishing internment camps for the Japanese - as one of the most shameful episodes of United States history. I hope that we will come to understand that the struggle for

assure the appearance of the person as required and the safety of any other person and the community." 18 U.S.C. § 3142(e)-(f) (2000).

75. Rasul v. Bush, 542 U.S. 466, 561 (2004).

76. See Hamdan v. Rumsfeld, 415 F.3d 33, 36 (D.C. Cir. 2005), cert. granted, 126 S. Ct. 622 (2005) ("The government's initial argument is that the district court should have abstained from exercising jurisdiction over Hamdan's habeas corpus petition."). See also Neil A. Lewis, Red Cross Criticizes Indefinite Detention in Guantanamo Bay, N.Y. TIMES, Oct. 10, 2003, at A1 ("Some officials, notably Defense Secretary Donald Rumsfeld, have said the detainees may be held until the effort against terrorism ends.").

77. Hamdan, $415 \mathrm{~F} .3 \mathrm{~d}$ at 42 . The court held that district courts could hear habeas petitions for the narrow purpose of determining whether the Guantanamo military commissions had proper jurisdiction over the detainees and substantively ruled that the military commissions were legal, rejecting both that the Geneva convention could be enforced in the United States and that it applied to the prisoners. Id. at $40-41$.

78. Yamamoto et al., supra note 13, at 1272.

79. Indeed, President Bush drew on the persuasive power of invoking the internment in his swearing in of Transportation Secretary Norman Minetta. He stated, "[Minetta's] life is a story of determination and courage and service. As a child, he lived in an internment camp." George W. Bush, Remarks by the President at Swearing-In Ceremony for Secretary of Transportation Norm Minetta (Feb. 8, 2001), available at http://www.whitehouse.gov/news/releases/2001/02/200102083.html. It is unlikely that Bush would enjoy being remembered among the ranks of those who incarcerated Secretary Minetta and his family. 
freedom from executive tyranny is a necessity; it is a struggle we all must join.

\section{B. Distancing Terrorism Policies from the Internment}

The invocation of past deprivations to caution against current government abuse is a broadly used tactic of civil libertarians in a wide array of issues, including gender discrimination, ${ }^{81}$ racial discrimination, ${ }^{82}$ and anti-Semitism. ${ }^{83}$ Feminists draw upon the struggles of the foremothers of enfranchisement to highlight the current struggle for gender equality. ${ }^{84}$ Race theorists discuss Jim Crow laws and segregation to caution against current de jure and de facto racism. ${ }^{85}$ Members of the Jewish community invoke the Holocaust to respond to current anti-

80. Michael Ratner, Moving Away From the Rule of Law: Military Tribunals, Executive Detentions and Torture, 24 CARDOZO L. REV. 1513, 1521-22 (2003).

81. Feminists, for example, counter the argument that "society has come a long way," making gender discrimination an antiquated issue. See Betty Friedan, Feminism's Next Step, N.Y. TIMES, July 5, 1981, § 6 (Magazine), at 13 ("The women's movement in some form will never be over. But the rights that women have struggled to win in the last decade are in deadly danger, with right-wing groups in Congress determined to gut laws against sex discrimination and to abolish legal abortion ...."').

82. Justice Ginsburg has responded to the argument that affirmative action is unjustified because society has progressed to the point where minorities have true equal opportunity:

[I]t remains the current reality that many minority students encounter markedly inadequate and unequal educational opportunities. Despite these inequalities, some minority students are able to meet the high threshold requirements set for admission to the country's finest undergraduate and graduate educational institutions. As lower school education in minority communities improves, an increase in the number of such students may be anticipated. From today's vantage point, one may hope, but not firmly forecast, that over the next generation's span, progress toward nondiscrimination and genuinely equal opportunity will make it safe to sunset affirmative action.

Grutter v. Bollinger, 539 U.S. 306, 346 (2003) (Ginsburg, J., concurring).

83. Scholars continue to invoke the "never again" catchphrase associated with the Holocaust as a discursive vehicle to criticize and engage in analysis of current genocides and government abuses. See, e.g., Winston P. Nagan \& Vivile F. Rodin, Racism Genocide \& Mass Murder: Toward a Legal Theory About Group Deprivations, 17 NAT'L BLACK L.J. 133, 221 (2003-04) (“'Never again' is a phrase that should be of universal relevance to Jews and non-Jews alike.").

84. See, e.g., JoEllen Lind, Dominance and Democracy: The Legacy of Woman Suffrage for the Voting Right, 5 UCLA WOMEN's L.J. 103, 198-204 (1994) (discussing the history of the gender enfranchisement movement as a vehicle for discussing the ways in which the Supreme Court has historically played and currently plays a role in reinforcing patterns of gender domination).

85. See, e.g., Jeffrey J. Wallace, Ideology vs. Reality: The Myth of Equal Opportunity in a Color Blind Society, 36 AKRON L. REV. 693, 705 (2003) ("America has had a long history of racism [and] discrimination . . . firmly rooted in the legacies of slavery, Jim Crowism, 'separate but equal,' and segregation. The problem plaguing America today is that it has not dealt with the deep-seated and fundamental attitudes of White superiority and Black inferiority and the presumption of a race neutral and a color blind society."). 
Semitism. ${ }^{86}$ The illustration of past harms is helpful in striving for full equality and cautioning against backsliding into or continuing to perpetuate bigotry and oppression.

Many, however, vigorously reject that society is still infested with tyranny and bigotry. These individuals argue that the status quo represents a neutral, or at least acceptable, set of norms - a "fair" playing field in which all, or at least most, members of society have equality of opportunity to achieve. ${ }^{87}$ When confronted with comparisons of current situations to past deprivations of liberty and equality, conservative defenders of the status quo often respond by asserting that society has "gotten better" and thus comparisons to past abuses are not only disanalogous but also disingenuous. ${ }^{88}$

In this vein, many dismiss arguments that the Bush Administration is abusing rights and assert the Administration is responding to the threat of terrorism appropriately, fairly, and with due regard for procedural safeguards. ${ }^{89}$ They argue that the government has struck the correct balance between liberty and security without exceeding the boundaries of executive power. Bush Administration supporters claim that critics mistakenly view its policies as abusive. One conservative scholar asserts, "To a surprising degree, opposition to the executive response to

86. See generally Vera Ranki, Holocaust History \& the Law: Recent Trials Emerging Theories, 9 CARDOZO STUD. L. \& LiTERATURE 15 passim (1997) (discussing the relevance of the Holocaust in a postmodern legal world).

87. In response to pro-affirmative action arguments, conservative Larry Elder asserts that "the progress of American blacks is simply astounding" and concludes that "[t]he road to success is simple, if not easily applied-hard work, sacrifice, and above all, the refusal to think like a victicrat." Larry Elder, The Progress of American Blacks, CAPITALiSM MagaZine, Sept. 4, 2004, http://capmag.com/article.asp?ID=3900.

88. Conservative Michael Horowitz argues against slavery reparations:

No evidence-based attempt has been made to prove that living individuals have been adversely affected by a slave system that was ended over 150 years ago. But there is plenty of evidence the hardships that occurred were hardships that individuals could and did overcome. The black middle-class in America is a prosperous community that is now larger in absolute terms than the black underclass.

David Horowitz, Ten Reasons Why Reparations for Blacks is a Bad Idea for Blacks-and Racist Too, Front Page Magazine, Jan. 3, 2001, http://www.frontpagemag.com/Articles/ReadArticle. asp? ID $=1153$.

89. See, e.g., David E. Sanger, The Cheney World View, With an Emphasis on Boldness, N.Y. TIMES, Sept. 2, 2004, at P3 ("[T] he nation could not be safe without a president who was instinctively ready to go on offense to eliminate threats to the United States."); Laura McCallum, Republicans Praise Bush's Handling of Terrorism; Delegates Approve Platform, MinNesota PUBLIC RADIO, Aug. 4, 2004, http://news.minnesota.publicradio.org/features/2004/08/30_ap_ rncday1/ (discussing President Bush's 2004 political platform and citing various sources of support for his re-election). 
terror is premised on a mistaken, and sometimes overly apocalyptic, depiction of the powers that have accrued to the government." 90

Defenders of the War on Terror offer different responses to the civil libertarian invocation of Korematsu. More radical Bush supporters actually justify the Japanese internment as both necessary and vital to the defense of the nation and, indeed, the safety of the Japanese, and conclude that the internment is not an instance of tyranny at all. ${ }^{91}$ For example, Congressman Howard Coble, then Chairman of the Judiciary Subcommittee on Crime, Terrorism and Homeland Security, stated during a 2003 radio interview:

"We were at war. [Japanese Americans] were an endangered species" ... "For many of these Japanese-Americans, it wasn't safe for them to be on the street."

....

"Some probably were intent on doing harm to us"... just as some of these Arab Americans are probably intent on doing harm to us.",92

Most Bush Administration defenders, however, seek to distance current policies from Roosevelt's policies regarding the Japanese. These distancing tactics are not only set forth by the political right, but also by scholars who take an optimistic view of society's ability to learn from past atrocities. There are several types of distancing arguments advanced by defenders of the status quo, which are analyzed below.

Some distancing arguments highlight factual differences between the internment and current detentions. They assert the government interned the Japanese solely on the basis of racial prejudice and contrast the Japanese internment with, for example, Yaser Hamdi's detention, which they characterize as based upon individual dangerous conduct. ${ }^{93}$ Supporters of Secretary Rumsfeld in Hamdi argued against internment comparisons, stating, "Hamdi introduced no evidence of unreasonable racial stereotyping" and "the Mobbs Declaration does not recite generalizations regarding groups of which Hamdi happens to be a member; rather, it recites specific facts regarding Hamdi's actions in

90. Paul Rosenzweig, Civil Liberty and the Response to Terrorism, 42 DUQ. L. REV. 663, 666 (2004).

91. See, e.g., Michelle Malkin, In Defense of Internment: The Case for "Racial PROFILING" IN WORLD WAR II AND THE WAR ON TERROR Xxxiii-Xxxv (2004).

92. N.C. Rep.: WWII Internment Camps Were Meant to Help, ASSOCIATED PRESS, February 05, 2003, http://www.foxnews.com/story/0,2933,77677,00.html (quoting Howard Coble).

93. See infra notes 278-85 and accompanying text (discussing bases for Hamdi's classification). 
support of the Taliban war effort." $" 94$ Such arguments distance current policies from the internment by claiming that while impermissible racism underlay the internment, "legitimate" justifications underlie the current terrorism detentions.

Critics of the Administration advance several responses to the contention that the current detentions are not racialized. First, they argue that the Bush Administration is, in fact, overtly embracing many racebased antiterrorism policies. ${ }^{95}$ Moreover, scholars note that, while perhaps not as obvious, there is a definitive racial dimension to the terrorism detentions, including Hamdi's. ${ }^{96}$ They caution those quick to separate the "military judgment" in Hamdi's case from the "racism" in Korematsu's case to remember that the Supreme Court in Korematsu specifically deferred to DeWitt's racist assumptions as proper "military judgment." Professor Thomas W. Joo observes that "the "Arab' racial construct has rapidly taken center stage in the wake of September 11" and cautions that "[r]ace and executive power are closely intertwined in the current national security crisis, as they have been in past crises, real and perceived." 97

Other distancing arguments distinguish the internment by comparing the severity of the internment to the severity of current antiterrorism policies. Professor Eric Muller, for example, proposes that in assessing current policies, we should "step out of the shadow" of Korematsu. ${ }^{98}$ Rejecting the contention that race-based reasoning is never acceptable, ${ }^{99}$ he states, "I have shown that, to the extent one must identify a 'fundamental error' in the Japanese-American internment, it was not the inference that supported the program but the staggering burdens that the program imposed on the strength of that inference."100 Muller further characterizes Bush's actions as comparatively restrained and attempts to sanitize Bush's race-based interrogation policies on the ground that

94. Brief for Washington Legal Foundation et al. as Amici Curiae Supporting Respondents at 21, Hamdi v. Rumsfeld, 542 U.S. 507 (2004) (No. 03-6696).

95. See, e.g., Lugosi, supra note 36, at 241 (asserting the possibility that Hamdi's incarceration was because of his ethnic origin); Serrano \& Minami, supra note 12 , at 46 (discussing the FBI \& INS's use of racial profiling).

96. See Iijima, supra note 13, at 128-34 (discussing the racial underpinnings of the Hamdi case).

97. Thomas W. Joo, Presumed Disloyal: Executive Power, Judicial Deference, and the Construction of Race Before and After September 11, 34 Colum. Hum. RTS. L. REV. 1, 46-47 (2002). He explains, "Excessive deference to the executive may legitimate racial reasoning, and racial reasoning may legitimate expansion of executive power." Id. at 47.

98. Muller, supra note 15 , at 130.

99. Id.

100. Id. at 119 . 
the Bush administration was acting on an inference not that young male Arab aliens who had arrived on certain sorts of visas during a specified time period might be terrorists, but that they might be more likely than others to know terrorists, or to have information that seemed innocent to them but would be useful to investigators. ${ }^{101}$

One can certainly question Muller's contention that selective detention and interrogation of Arab men is acceptable because they were not presumed to be terrorists. ${ }^{102}$ During the internment, the presumed disloyalty of the Japanese was not the only basis for detention. Rather, government officials posited many "neutral" reasons for the internment including preventing Japanese soldiers from posing as Americans and protecting Japanese Americans from external harm. ${ }^{103}$ Moreover, many would disagree with the specific contention that race-based policies are acceptable so long as the attendant deprivations are not great. ${ }^{104}$ As the Supreme Court has recognized elsewhere, there is harm inherent in racial decision making. ${ }^{105}$ Both the internment and current racial profiling demonstrate such harm with particularity. ${ }^{106}$ Consequently, it is not

101. Id. at $122-23$ (footnotes omitted).

102. See Natsu Taylor Saito, Symbolism Under Siege: Japanese American Redress and the "Racing" of Arab Americans as "Terrorists," 8 ASIAN L.J. 1, 11-17 (2001) (comparing experiences of today's Arabs and Muslims being racially constructed as terrorists to experiences of wartime Japanese Americans being racially constructed as saboteurs); see also Adam Liptak, For Post-9/11 Material Witness, It Is a Terror of a Different Kind, N.Y. TIMES, Aug. 19, 2004, at A1 (explaining the use of material witness detention against Arabs after 9/11).

103. See InTERnMENT OF Civilians, supra note 1, at 176 (quoting Lt. Gen. John L. DeWitt as saying, "the question of the alien Japanese and all Japanese presents a problem in control, separate and distinct from that of the German and Italian.”); MORTON GRODZINS, AMERICANS BETRAYED: POLITICS AND THE JAPANESE EVACUATION 109 (1949) (quoting Portland Mayor Earl Riley testifying before the Tolan Committee stating, "for [the Japanese Americans'] own protection, they should be evacuated").

104. Consider the following hypothetical: During World War II, officials in their "military expertise" determined that there would be an invasion of certain areas of California. They deemed it necessary to evacuate a portion of California, install military operations there, and relocate all 100,000 residents of a town. In fact, this military judgment was based on reckless intelligence gathering, faulty assumptions, and incompetence. In retrospect, many would consider this action a terrible mistake and condemn the negligent intelligence gathering. However, it can hardly be said that this scenario adequately mirrors the harm and shame of the Japanese internment.

105. See Batson v. Kentucky, 476 U.S. 79 (1986) (prohibiting race-based juror challenges and emphasizing the idea that racialized harm is distinct from other harms). See also Tania Tetlow, How Batson Spawned Shaw-Requiring the Government to Treat Citizens as Individuals When it Cannot, 49 LOY. L. REV. 133, 144 (2004) ("The Batson cases did not depend entirely on the argument that race is irrelevant to predictions of the voting behavior of a particular juror. The majority relied more heavily on the argument that racial stereotypes, regardless of their truth, cause harm."). The Supreme Court has recognized that racial discrimination not only harms individuals tangibly, but also harms entire races psychologically and governmental integrity generally. See Bush v. Vera, 517 U.S. 952, 985 (1996) (explaining the harms caused by racial stereotyping).

106. See Saito, supra note 102, at 9 (stating that "as we look briefly at the history of Asians in America, we see the internment emerging as a somewhat extreme, but not aberrant, manifestation of 
accurate to state that a faulty racial judgment is no worse than a faulty military judgment.

Likewise, it is untenable to hold that a "correct"107 racial judgment stands on the same footing as any other military judgment, so long as it does not lead to enormous deprivations. ${ }^{108}$ Even assuming that current deprivations are not as bad as in World War II, which is not necessarily true ${ }^{109}$ the current security situation is also not as dire as in World War II, which involved an imminent invasion during a world war. The Roosevelt Administration thus set racist and extremely harmful policy in the face of a massive threat. The Bush Administration set racist and harmful, albeit less sweeping, policy in the face of a much less severe threat. ${ }^{110}$ In the wake of $9 / 11$, a single attack carried out by a terrorist group, not a nation, the Bush Administration has initiated two wars and detained thousands of individuals. ${ }^{111}$ First, many would scoff at the notion that such actions evidence "restraint." Moreover, any "restrained" nature of Bush's policies may be less a function of society's evolution and more a function of the fact that the predicate danger has not reached the level of World War II. ${ }^{112}$ Because the government is currently engaging in race-based deprivations with relatively minimal predicate danger logically indicates that when faced with graver dangers, like those

a well-entrenched pattern of discrimination rooted in a racialized identification of Asian-Americans as perpetually 'foreign"').

107. Whether racial judgments can be correct is questionable. See, e.g., Jeremiah Wagner, Racial (De)Profiling: Modeling a Remedy For Racial Profiling After the School Desegregation Cases, 22 LAW \& INEQ. 73, 88 (2004) (stating that racial profiling "becomes 'a self-fulfilling prophecy where law enforcement agencies rely on arrest data that they themselves generated as a result of the discretionary allocation of resources and targeted drug enforcement efforts" (quoting David Rudovsky, Breaking the Pattern of Racial Profiling, 38 TRIAL 29, 30 (2002)).

108. See Muller, supra note 15, at 130 (noting that "profiling might sometimes be rational").

109. One could contest the argument that the current terrorism cases do not represent as grave a deprivation as the Japanese internment. Although there may be fewer terrorism detainees than there were internees, terrorism detention is much harsher. Terror detainees are held in jails, and sometimes in barbed wire and cages. They are kept from their families and held incommunicado, save for regular interrogation by U.S. officials. See infra notes 526-28 and accompanying text (describing conditions for terrorism detainees); see also AMNESTY INTERNATIONAL, HUMAN DigNITY DENIED: TORTURE AND ACCOUNTABILITY IN THE 'WAR ON TERROR' (2004), http://web.amnesty.org/library/Index/ENGAMR511452004.

110. Of course, proponents of racial profiling as part of the War on Terror paint a grim picture of America's security situation. See Michael Stokes Paulsen, The Constitution of Necessity, 79 NOTRE DAME L. REV. 1257, 1281 (2004) (asserting that racial profiling is justified by "compelling interests in national self-preservation, national security, and protection of innocent civilians from military or terrorist attack by foreign enemies"). Such danger, however, can barely be compared to the dangers of full-blown war and invasion.

111. PEARLSTEIN, supra note 17 , at 7.

112. See infra notes 168-77, 192-95 and accompanying text (Supreme Court description of the threat facing the United States during World War II). 
of World War II, the Administration will resort to more repressive racial policies. ${ }^{113}$

Other distancing arguments are not related to race but rather to the issue of unfair detention. Some defenders of the terrorism detentions offer unsupported yet vehement assertions that invocations of Korematsu are misplaced. ${ }^{114}$ The Fourth Circuit in Hamdi, for example, summarily stated, "There is not the slightest resemblance of a foreign battlefield detention to the roundly and properly discredited mass arrest and detention of Japanese-Americans in California in Korematsu." "115 The district court in Padilla ex rel. Newman v. Rumsfeld ${ }^{116}$ similarly dismissed the invocation of Korematsu as an example of partisan alarmism. ${ }^{117}$ Others forge more substantive arguments distinguishing the internment from current detention policy.

Professor Mark Tushnet, for example, has "defended" Korematsu as a process of "social learning" whereby past discredited suspensions of civil liberties remain in the collective social conscious and serve to limit future suspensions of civil liberties. ${ }^{118}$ Tushnet hypothesizes that during times of emergency, the government acts hastily on imperfect information; ${ }^{119}$ military judgment is exercised; and executive deference is widespread. $^{120}$ Judges are loath to intervene in substantive policy making, and they exercise judicial oversight, if at all, in an ex post

113. Bruce Ackerman provides a bleak view of the state of future civil liberties: After each successful attack, politicians will come up with repressive laws and promise greater security - only to find that a different terrorist band manages to strike a few years later.... Even if the next half-century sees only four or five attacks on the scale of September 11, this destructive cycle will prove devastating to civil liberties by 2050 .

Bruce Ackerman, The Emergency Constitution, 113 YALE L.J. 1029, 1029-30 (2004).

114. Others go even farther and argue that, in fact, current terrorism detainees enjoy too much process. See e.g., Matthew J. Franck, Harmful Rulings: Enemy Combatants and an Irresponsible Court, NAT'L REVIEW, June 29, 2004, http://www.nationalreview.com/comment/franck 200406291303.asp (criticizing the Hamdi and Rasul decisions for granting too many rights to detainees).

115. Hamdi v. Rumsfeld, 337 F.3d 335, 344 (4th Cir. 2003).

116. 243 F. Supp. 2d 42 (S.D.N.Y. 2003), aff'd in part, rev'd in part sub nom. Padilla v. Rumsfeld, 352 F.3d 695 (2d Cir. 2003), rev'd, 542 U.S. 426 (2004).

117. The court criticized the government's hyperbolic assertion that giving Padilla counsel would lead to terrorist attacks but noted, "More than a match for that are passages in the amicus curiae submissions in this case, where lawyers raise the specter of Korematsu v. United States." 243 F. Supp. 2d at 57.

118. Tushnet, supra note 14 , at 274.

119. See id. at 291 ("The fact that policies are developed in uncertain times on the basis of information not fully available outside the decision-making bureaucracy may account for the courts' initial acquiescence in the policies, and for the subsequent critical reactions when the previously unavailable information becomes available.").

120. Id. at 294. 
fashion. ${ }^{121}$ The result is that many emergency decisions abridging civil liberties are repudiated only in future times when more accurate information is available. ${ }^{122}$ His view of the cycle of military misjudgment, civil liberty abridgment, and executive deference, however, is optimistic. The government does not in fact repeat the same mistakes over and over. Rather, with each successive emergency, the government's policies become less hasty and less extreme. ${ }^{123}$ To illustrate this point, Tushnet highlights differences between Roosevelt's actions and Bush's terrorism policies. ${ }^{124}$ Although he characterizes Bush's philosophy as virtually identical to that of the wartime Roosevelt Administration, he asserts that social learning is evidenced by the Bush Administration's failure to act to the full extent of its claimed power. ${ }^{125}$ Asserting that "by and large [Bush's] actions have been more restrained than would be authorized by the administration's asserted legal theories," Tushnet concludes, "Social learning elsewhere in the society appears to have produced a political dynamic that restrains the administration." 126

Professor Tushnet's hypothesis about social learning is based in part on empirical conclusions about the way the public and government officials think and behave. ${ }^{127} \mathrm{He}$ seems to assume that public awareness of civil liberties and race relations has evolved since World War II. There is evidence, however, that this is not the case. Just as there was general public support but particular civil libertarian outcry during the internment, ${ }^{128}$ there is general public support but particular civil libertarian resistance to post-9/11 anti-Arab policies. ${ }^{129}$ Like the scholars

121. Id. at 291. See also Baker, supra note 33, at 220 (asserting that during emergencies, judicial review is exercised rarely and then only after the fact).

122. See Tushnet, supra note 14, at 287 ("The retrospective critical view is a compound of two other judgments: that the threat to which the actions were responses was exaggerated, and that the responses were excessive in relation to the exaggerated threats (obviously) and even to the real threats that existed.")

123. Id at $283-84$. In fairness, Tushnet qualifies his theory by noting that social learning is imperfect and that there is not always a fair analogy to be drawn between past emergencies and present threats. He states, "We learn from our mistakes to the extent that we do not repeat precisely the same errors, but it seems that we do not learn enough to keep us from making new and different mistakes." Id. at 292.

124. Id. at 295-96.

125. Id. at 296 .

126. Id.

127. Id. at 305 .

128. See GRODZINS, supra note 103, at 197 (noting the criticisms of mass evacuation from civil libertarian groups); Sumi Cho, Redeeming Whiteness in the Shadow of Internment: Earl Warren, Brown, and a Theory of Racial Redemption, 40 B.C. L. REV. 73, 111 (1998) (describing popular support for internment).

129. See supra note 19 and accompanying text (addressing the concerns of civil libertarians that individuals are being deprived of their liberty). 
who currently criticize Bush, during World War II, "[1]awyers ... openly discussed the constitutional barriers to a mass internment of civilians based on racial classification.",130

Moreover, the fact that the Bush Administration and general public are not calling for Arab internment may be more a product of the specific circumstances facing the nation than a product of social learning. ${ }^{131}$ The Bush Administration's seemingly "restrained" manner may be explained better by other specific factual circumstances than the Administration's having learned from the internment. ${ }^{132}$ Consequently, one may hypothesize that the public and politicians have learned from past abuses, but this hypothesis is difficult to support by clear empirical evidence because the factual differences between post-9/11 America and World War II America are compelling enough to explain any differences between the Bush and Roosevelt Administrations' policies.

Professor Tushnet's distancing argument, however, is not solely based on empirical claims about the public and government's ability to learn from past events. ${ }^{133} \mathrm{He}$ also sets forth a legal basis for society's claimed evolutionary progression. ${ }^{134}$ Tushnet asserts, "Judges and scholars develop doctrines and approaches that preclude the repetition of

130. Gott, supra note 69 , at 226. Professor Gott observes that there was in fact a social outcry against the internment:

Initial public opinion among whites after Japan's attack did not suggest that concentration camps were imminent. Even the Los Angeles Times, which would later play a key role in fanning the flames of racist hatred, initially published editorials that defended the loyalty of Japanese Americans, referring to them as "good Americans." Id.

131. For example, the diversity of ethnicities represented by Arabs and Muslims would complicate any project of mass internment. See Chisun Lee, Rounding Up the 'Enemy:' Sixty Years After It Jailed Japanese Americans, Would the U.S. Consider Another Ethnic Internment?, THE Village VOICE, July 31-Aug. 6, 2002, available at http:/www.villagevoice.com/ issues/0231/lee.php (explaining that "the diversity of nationalities linked to today's terrorism might complicate a massive roundup"). Moreover, the Bush Administration has utilized its ability to hold internees abroad and in secrecy, which would have been difficult to accomplish during World War II. See supra note 17.

132. These circumstances include the ability of the Bush Administration to intern many Arabs and Muslims on immigration grounds, the diverse nature of the group, the lack of recent attacks inside the United States, the prohibitive costs, Bush's obsession with Iraq, and the ability to carry out extraterritorial secret detentions. One should be skeptical of purported Bush Administration restraint, given its consistent position that there should be unfettered executive discretion when it comes to national security decisions. In fact, Bush and his supporters have sought to establish even greater executive power to act unilaterally than what previously existed. See, e.g., Brief for American Center for Law \& Justice as Amici Curiae supporting Petitioners, Rumsfeld v. Padilla, 542 U.S. 426 (2004) (No. 03-1027) (arguing that Bush's actions regarding Padilla were nonjusticiable political questions).

133. Tushnet, supra note 14, at 292.

134. Id. 
the last generation's mistakes." 135 Initially, one may wonder just how far removed from the last deprivation courts must be to exercise such retrospective evaluation. Indeed, the Korematsu Court, even given the "calm perspective of hindsight," $" 136$ did not create a doctrine of repudiation or restraint. In fact, the Court did what Tushnet objects to most when it incorporated wartime political decision making into the body of the Constitution. ${ }^{137}$ Tushnet, of course, could respond that the Korematsu decision came at a politicized and still tumultuous time, such that the Court was guided by popular passion and could not exercise calm hindsight. Given that more than a half-century has passed since World War II, the Supreme Court should have done better with Padilla and Hamdi. ${ }^{138}$ The question is whether it has.

\section{Law as the Framework for Assessing the Distancing Arguments}

In examining whether the government has improved its treatment of civil rights since Korematsu, this Article concentrates on the Supreme Court's legal choices as the measure of progress. While one could look at factors such as public opinion, governmental actions, or media to gauge the movement of society, ${ }^{139}$ such empirical factors might not be good indicators of progress because they are difficult to quantify ${ }^{140}$ and depend on variable conditions. ${ }^{141}$ Moreover, the United States of today

135. Id.

136. Korematsu v. United States, 323 U.S. 214, 224 (1944).

137. Much to the disappointment of Justice Jackson, see infra notes 148-49 and accompanying text, the Court ruled that the government had the constitutional authority to create the exclusion order and that such order comported with the dictates of the Equal Protection Clause. Korematsu, 323 U.S. at 224.

138. The legal repudiation of the internment has largely been a product of nonjudicial commentary. The few cases that comment on the internment criticize it in dicta only. As a result, Korematsu is technically "good law." Nowhere in any of the terrorism cases does the Court take the opportunity to condemn Korematsu or Hirabayashi.

139. Tushnet, supra note 14 , at 283-84.

140. Public opinion is notoriously difficult to gauge. Moreover, opinion polls show that the public is not sensitized to the concept of race-based internment. Research shows that nearly the same percentage of New Yorkers supported Arab internment camps two years after 9/11 as two weeks after. See Marc Humbert, Poll: Third of New Yorkers Support Internment Camps for Some, ASSOCIATED PRESS, Sept. 24, 2001, available at http:/www.sweetliberty.org/issues/war/safety/ nyinternment.htm.

141. See Karen Patterson, The American Psyche; Shaken and Stirred by Attacks, We're United in Our Individualism, DALLAS MORNING NEWS, Sept. 1, 2002, at 1J (stating that many of the studies of attitudes toward Arab Americans are not fully accurate because they were "assembled hastily, have small numbers of subjects, lack random samples, and focus on college students"). It is indeed difficult to determine where Americans generally stand on Bush's policies. This is evident simply by looking at opinion polls of his performance throughout his first term. The results of a number of polls can be found at http://pollingreport.com/terror.htm. 
is faced with extremely different factual circumstances than the United States of the 1940s. Because of the distinctions between World War II and $9 / 11$, it is difficult to conclude that current policy and social attitude evidence an advancing civil libertarian learning curve. Consequently, this Article considers legal movements as a more concrete and accurate way of examining the evolution of society's disposition toward civil liberties. The movement in Supreme Court jurisprudence, for example, from Dred Scott v. Sanford, ${ }^{142}$ to Brown v. Board of Education, ${ }^{143}$ to Regents at the University of California v. Bakke, ${ }^{144}$ back to Adarand Constructors, Inc. v. Dena, ${ }^{145}$ and again to Grutter v. Bollinger, ${ }^{146}$ says something about the progression of society in the arena of civil rights, equal protection, and race relations.

In addition to being a more administrable way of measuring the progress of society, the law plays a special role as both a legitimator of de facto conditions and a creator of new societal dispositions. Professor Thomas W. Joo observes, "Because of its peculiar position as the official voice of society, law plays an important role in the construction of social institutions and beliefs, even those that are not typically considered 'legal."'147 This is precisely why Justice Jackson feared the legacy of the Korematsu decision, even though by the time the Korematsu decision was issued, the camps were officially finished. ${ }^{148} \mathrm{He}$ decried the ability of Korematsu to "lie[] about like a loaded weapon ready for the hand of any authority that can bring forward a plausible claim of an urgent need." "149 On a related note, Professor Tushnet argues that emergency detention power should be expressly exempted from constitutional

142. 60 U.S. 393 (1857) (holding that Dred Scott, a black man, was not permitted citizenship nor the ability to gain his freedom by moving into a free territory).

143. 347 U.S. 483 (1954) (holding "separate but equal" doctrine unconstitutional and requiring racial integration of schools).

144. 438 U.S. 265 (1978) (permitting government funded school to consider race in admissions to the Universities of California, relying on value of diversity).

145. 515 U.S. 200 (1995) (disallowing government to consider race in the granting of contracts despite diversity gains).

146. 539 U.S. 306 (2003) (reaffirming Bakke and holding that schools may take into account race in admissions for diversity purposes).

147. Joo, supra note 97, at 1 . He further states, "By demanding precise articulation and justification, law can transform vague and contested ideas into legitimate and even enforceable concepts. In doing so, the law not only reflects social institutions but actively constructs them." Id. at $1-2$.

148. Korematsu was decided on December 18, 1944. Korematsu v. United States, 323 U.S. 214 (1944). Public Proclamation 21, which rescinded General DeWitt's mass exclusion order, was issued on December 17, 1944, thus marking the official end of internment policies. See NG, supra note 8, at 97 (discussing Public Proclamation 21).

149. Korematsu, 323 U.S. at 246 (Jackson, J., dissenting). 
analysis precisely because of the force of the rule of law. ${ }^{150}$ His concern is that judicial opinions rationalizing expansive executive power during exigencies will lead to the President's invocation of such powers more often and in less exigent circumstances. ${ }^{151}$

The role of the courts in times of emergency is a popular topic for legal scholars. One prominent theorist, Professor Bruce Ackerman, has hypothesized an alternate constitutional paradigm that would allow for some legislative control over military decisions, while relieving courts of any obligation to rule on their constitutionality. ${ }^{152}$ Others reject the premise that courts should stay out of emergency decision making and argue for a jealous guarding of judicial power to vindicate civil liberties. David Cole, for example, urges that no matter the emergency, "[p]utting innocent people who pose no danger behind bars to reassure a panicked public is normatively unacceptable." 153 This Article neither supports an alternate constitutional scheme to account for judicial abdication during times of emergency, nor defends the ability of the Court to avoid political pressure. ${ }^{154}$ Rather, it recognizes that novel constitutional

150. Tushnet, supra note 14 , at 304-05.

151. Id. at 303-04.

152. See Ackerman, supra note 113, at 1037 ("My aim is to design a constitutional framework for a temporary state of emergency that enables government to discharge the reassurance function without doing long-term damage to individual rights."). Ackerman sees the structure of judicial review as historically and currently incapable of managing the executive's drive to impose longlasting limitations on liberty. $I d$. at $1029-30$. He thus proposes a system in which the legislature acts as a "supermajoritarian escalator" such that as the length of emergency detention increases, the legislature must vote with increasing unanimity to maintain it. $I d$. at 1042 . Judicial review is extremely limited. Id. at 1067-68. Ackerman concludes that the "emergency constitution," which compels legislative oversight, is better than a system in which the courts handle emergency matters through total judicial abdication. Id.

153. David Cole, The Priority of Morality: The Emergency Constitution's Blind Spot, 113 YALE L.J. 1753, 1758 (2004). He further states, "Ackerman proposes to do away with the two guarantees essential to any acceptable system of nonwartime preventive detention-a threshold requirement of objective suspicion and access to prompt judicial review. Eliminating either guarantee would violate fundamental commands of both American constitutional law and international human rights law." $I d$. at 1759. Cole also expresses skepticism about the ability of the legislature, even as constructed by Ackerman, to be the vindicator of individual rights during times of emergency. Id. at 1764 . Moreover, Cole is less pessimistic about the judicial ability to control the government in the aftermath of terrorist attacks. Id. at 1763 .

154. This Article seeks to caution against harmful rulings, while recognizing that the Court has some potential to rule the correct way. This is not to say, however, that the Court is immune to social and political pressures. However, the fact that social and political pressure caused an unjust decision by the Supreme Court does not necessarily justify tinkering with the structure of government to account for the decision. Rather the sentiments giving rise to the political or social pressure and the attendant unjust decisions should be addressed as a matter of law, policy, and theory. Dealing with external prejudices has been a struggle of the Supreme Court for generations. 
construction and judicial abdication are examples of the many jurisprudential choices made by courts. ${ }^{155}$

The issue central to this Article is whether the current Supreme Court's choices in the terrorism cases evidence progress, such that the admonitory invocation of the internment is no longer expedient. Because the terrorism cases make no mention of race or equal protection, it is difficult to compare the equal protection dimensions of the internment and terrorism cases. As a result, this jurisprudential comparison will concern choices made by the Court regarding detention power and process, without specific regard to race. ${ }^{156}$ As a preface to this analysis, Part III summarizes the relevant internment and terrorism detention cases.

\section{THE INTERNMENT AND TERRORISM DETENTION CASES}

\section{A. The Internment Cases}

\section{Hirabayashi v. United States}

Gordon Hirabayashi's case ${ }^{157}$ was the first of a series of cases challenging the World War II restrictions on the rights of the Japanese decided by the Supreme Court. ${ }^{158}$ After the formal declaration of war against Japan, the President issued Executive Order 9066, which called for "every possible protection against espionage and sabotage," 159 and served as the basis for several military directives restricting the rights of

155. I leave it to constitutionalists and legal positivists to worry about courts destroying constitutional text or the purity of precedence to bolster executive power during emergencies. Justice Scalia, for example, decries the plurality's "Mr. Fix-It Mentality" in Hamdi. Hamdi v. Rumsfeld, 542 U.S. 507, 628 (Scalia, J., dissenting) ("The plurality seems to view it as its mission to Make Everything Come Out Right."). Thomas Baker similarly criticizes the lasting effect of "crisis" rulings. Thomas E. Baker, Civil Rights and Civil Liberties in a Crisis: A Few Pages of History, 3 NEV. L.J. 23, 23 (2002) ("The lasting problem is that, when the crisis is over and things get back to normal, we tend to hold onto the crisis constitution instead of returning to the normal constitution.").

156. One could argue that the Supreme Court made a specific jurisprudential choice in not addressing the underlying racial issues in any of the internment cases. On the other hand, because of the paucity of detainees in Hamdi's and Padilla's situations, it was difficult for either party to make specific racial claims. Even if the parties had asked the Court to examine the total of the 9/11related domestic detentions, they would likely have been unable to establish a prima facie claim of discrimination.

157. Hirabayashi v. United States, 320 U.S. 81 (1943).

158. Other cases in the series were Ex parte Endo, 323 U.S. 283 (1944); Korematsu v. United States, 323 U.S. 214 (1944); Yasui v. United States, 320 U.S. 115 (1943).

159. Exec. Order No. 9066, 7 Fed. Reg. 1, 1407 (Feb. 19, 1942). 
the Japanese. ${ }^{160}$ Hirabayashi, an American citizen and resident of Seattle, ${ }^{161}$ was indicted for violating the curfew provision of Public Proclamation No. 3, which regulated specified military areas. ${ }^{162}$ Hirabayashi challenged the constitutionality of the indictment, claiming that the relevant military orders and proclamations violated the Fifth Amendment and Article IV, Section 2, Clause 1 of the U.S. Constitution. ${ }^{163}$

The district court rejected Hirabayashi's claims, prefacing its decision with a description of the grave exigency that triggered the government's power to impose curfews. ${ }^{164}$ The court cautioned that its decision should be viewed "in the light of the unprecedented world conflict which so suddenly engulfed this nation." 165 The district court held that Congress and the President, acting together, had the power to enact the restrictions at issue. ${ }^{166}$ The Court observed that Congress had authorized the curfew order through The Act of March 21, 1942, which explicitly made it a crime to "leave, or commit any act in any military area or military zone prescribed, under the authority of an Executive Order of the President ... or by any military commander . . . contrary to the restrictions applicable to any such area or zone."

The Ninth Circuit declined to rule on the order and certified the constitutional issues to the Supreme Court. The Supreme Court, like the district court, first emphasized that the government's actions "must be

160. Hirabayashi, 320 U.S. at 83-84.

161. Seattle had been designated a Military Area by General DeWitt on March 2, 1942. Id. at 86-87.

162. United States v. Hirabayashi, 46 F. Supp. 657, 659 (W.D. Wash. 1942), aff'd, 320 U.S. 81 (1943).

163. Id. at 661

164. The court observed,

[W] have been engaged in a total war with enemies unbelievably treacherous and wholly ruthless, who intend to totally destroy this nation, its Constitution, our way of life, and trample all liberty and freedom everywhere from this earth. It must be realized that civilization itself is at stake in this global conflict.

Id. at 659 .

165. Id.

166. Id. Interestingly, a dialectical tool employed by the district court in furtherance of its goal of rejecting Hirabayashi's claims was to contrast the character of the war as grave and fundamental with the character of Hirabayashi's rights as minor and technical. The court stated that Hirabayashi was given the "privilege" of challenging his indictment and concluded that a "technical right of an individual should not be permitted to endanger all of the constitutional rights of the whole citizenry." Id. at 658, 661 (emphasis added).

167. Act of Mar. 21, 1942, ch. 191, 56 Stat. 173. The court then rejected Hirabayashi's equal protection argument by holding that there was no federal right of equal protection, observing that "the Fifth Amendment, unlike the Fourteenth, has no equal protection clause." Hirabayashi, $46 \mathrm{~F}$. Supp. at 661 (quoting Sunshine Anthracite Coal Co. v. Adkins, 310 U.S. 381, 401 (1940)). 
appraised in the light of the conditions with which the President and Congress were confronted." 168 Specifically, the Court observed that military officials needed to "consider our internal situation" in light of "the danger of invasion." "169 The Court then turned to the issue of whether Congress had unlawfully delegated its legislative authority by allowing military commanders to promulgate the curfew restriction. The Court decided this issue by examining whether Congress itself had authorized the curfew order. Relying on the language and legislative history of the Act of March 21, 1942, ${ }^{170}$ the Court held that the Act authorized Executive Order 9066 generally and the curfew restrictions specifically ${ }^{171}$ and concluded that Congress had not unconstitutionally delegated its power. ${ }^{172}$

The Court also addressed whether the government had the power to subject citizens to the curfew restriction. ${ }^{173}$ Although it held that the curfew was a valid exercise of war power, ${ }^{174}$ the Court nonetheless required some showing on the part of the government as to the propriety of the restriction. The Court's inquiry was

whether in the light of all the facts and circumstances there was any substantial basis for the conclusion, in which Congress and the military commander united, that the curfew as applied was a protective measure necessary to meet the threat of sabotage and espionage which would substantially affect the war effort and which might reasonably be expected to aid a threatened enemy invasion. ${ }^{175}$

In one of the most disturbing instances of judicial fact finding, the Court determined that the government had provided evidence establishing a "substantial basis" for the conclusion that Japanese Americans posed a threat. ${ }^{176}$ Sadly, the Court relied on the purported isolation of the Japanese-American community, largely produced by preexisting racist laws, to support the theory that Japanese Americans could

\footnotetext{
168. Hirabayashi v. United States, 320 U.S. 81, 93 (1943).

169. Id. at 94. "The challenged orders were defense measures for the avowed purpose of safeguarding the military area in question, at a time of threatened air raids and invasion by the Japanese forces." Id. at 94-95. See also id. at 101 (noting that the government regulations occurred "in the crisis of war and of threatened invasion").

170. Id. at $89-91$

171. Id. at $91-92$

172. Id. at 104 .

173. Id. at 95-99.

174. Id. at 98-99.

175. $I d$. at 95 .

176. Id. at 96-97.
} 
be part of a disloyal "fifth column." 177 Based on this information, the Court opined, "we cannot reject as unfounded the judgment of the military authorities and of Congress that there were disloyal members of that population, whose number and strength could not be precisely and quickly ascertained." 178

In concluding that the government could constitutionally enact the curfew, the Court was careful to avoid commenting on the larger internment program. ${ }^{179}$ The Court stated that it was "immediately concerned with the question whether it is within the constitutional power of the national government ... to impose this restriction as an emergency war measure. The exercise of that power here involves no question of . . trial by military tribunal." 180

Justice Douglas concurred in the decision but disagreed with the notion of second guessing the judgment of military officials and criticized the majority for "assum[ing] that as a matter of policy it might have been wiser for the military to have dealt with these people on an individual basis." 181 He asserted that because the Court did not possess the ability to sit in judgment on military decisions, it was "necessary to concede that the army had the power to deal temporarily with these people on a group basis." "182 Justice Douglas took issue, however, with the characterization of the Japanese "problem" as one of assimilation rather than loyalty. ${ }^{183}$

177. Id. at 96-97 n.4. See supra notes 56-58 and accompanying text for criticism of the Court's analysis.

178. Hirabayashi, 320 U.S. at 99. Analyzing Hirabayashi's equal protection claims under due process, the Court's test was whether the government had asserted "a reasonable basis for the action taken in imposing the curfew." Id. at 101. The Court concluded that the classification passed constitutional muster because the particular "facts and circumstances" afforded some "ground for differentiating citizens of Japanese ancestry from other groups in the United States." Id.

179. Id. at 91-92. This piecemeal method of legal analysis, which allowed the courts to constitutionally approve the detention of citizens by dissecting the program down to its more innocuous parts, has been heavily criticized. See infra notes 206-09 and accompanying text.

180. Hirabayashi, 320 U.S. at 92.

181. Id. at 106 (Douglas, J., concurring).

182. Id. at 107

183. Id. at 107-08. Justice Douglas agreed that Hirabayashi had no right to test the constitutionality of the military orders by failing to follow them, but raised the important question of whether Hirabayashi should have been given an opportunity to contest his categorization as disloyal. $I d$. at 108. Justices Murphy and Rutledge, by contrast, separately concurred in the judgment and objected to any contention that the Court could not sit in judgment of military officials. Id. at 113 (Murphy, J., concurring); Id. at 114 (Rutledge, J., concurring). Justice Murphy was also careful to note that a racial classification could only be utilized in the most extreme circumstances of great emergency, cautioning that "to sanction discrimination between groups of United States citizens on the basis of ancestry ... goes to the very brink of constitutional power." Id. at 111 (Murphy, J., concurring). 


\section{Korematsu v. United States}

Fred Korematsu was convicted for violating a military order that excluded ethnic Japanese from portions of California. ${ }^{184}$ Korematsu appealed, and the case initially went before the Supreme Court on the government's contention that Korematsu could not appeal his conviction before sentencing. The Court held that the Ninth Circuit did have jurisdiction to hear Korematsu's appeal and remanded for consideration of the merits of the appeal. ${ }^{185}$

Interpreting the Supreme Court's decision in Hirabayashi as broadly standing for the proposition that "the United States, in prosecuting a war, has the power to do all that is necessary to the successful prosecution of a war although the exercise of those powers temporarily infringe some of the inherent rights and liberties of individual citizens," the Ninth Circuit engaged only in a superficial review of Korematsu's claims. ${ }^{186}$ The court concluded, "that [Hirabayashi's] principle, thus decided, so clearly sustains the validity of the proclamation for evacuation, which is here involved, that it is not necessary to labor the point." ${ }^{, 187}$ Without any discussion of the differences between curfew and exclusion or mention of the larger detention scheme, the court affirmed Korematsu's conviction.

Judge Denman, concurring in the result, agreed with the majority that General DeWitt's series of orders were justified by the extreme exigencies facing the nation, but chastised the Ninth Circuit for what he considered to be its total abdication of its judicial role by disposing of Korematsu's claims simply by citing Hirabayashi. ${ }^{188}$ He argued that the series of orders calling for Korematsu's exclusion and relocation materially differed from a mere curfew order. ${ }^{189}$ He also decried the court's refusal to see Korematsu's exclusion order as part of a larger detention scheme. ${ }^{190}$

184. Korematsu v. United States, 140 F.2d 289, 289 (9th Cir. 1943), aff'd, 323 U.S. 214 (1944). This order was part of the scheme to control the Japanese "Military Areas" covered by Civilian Exclusion Order No. 34. Korematsu v. United States, 319 U.S. 432, 433 n.1 (1943).

185. Korematsu, 319 U.S. at 435.

186. Korematsu, 140 F.2d at 290.

187. Id.

188. Id. at 291 (Denman, J., concurring) ("In this conspicuous appeal of such a member of one of America's minority groups, the opinion of this court disposes of Korematsu's major contentions without their mention, much less their consideration.").

189. Id.

190. Id. ("Outstanding is the avoidance of the question of imprisonment and deportation. It is buried in the euphemism 'evacuation,' without suggestion of its forced character or its accomplishment by compulsory confinement."). 
On certiorari, Justice Black, writing for the majority, began the opinion by introducing the equal protection test now known as "strict scrutiny," " observing that "all legal restrictions which curtail the civil rights of a single racial group are immediately suspect." $" 192$ The Court then turned to the issue of the government's power to restrict the rights of citizens during wartime. Relying primarily on the reasoning in Hirabayashi, the Court answered this question in the affirmative. ${ }^{193}$ As in Hirabayashi, the Court described the triggering warfare condition as particularly grave. Recognizing that exclusion was only permissible "under circumstances of direst emergency and peril," the Court opined that "when under conditions of modern warfare our shores are threatened by hostile forces, the power to protect must be commensurate with the threatened danger." $" 194$

Combined with this description of the dire nature of the triggering emergency was a deliberate minimization of the restrictions imposed on the Japanese. Rather than recognizing exclusion as part of the larger incarceration scheme, which at the time of the opinion had already forced thousands of Japanese families into detention, the Court adopted a piecemeal approach, considering the exclusion order standing alone. ${ }^{195}$ The Court stated, "we cannot say either as a matter of fact or law that his presence in [an assembly] center would have resulted in his detention in a relocation center." 196 In addition to reducing the issue to the sole question of exclusion, the Court minimized the severity of the relocation centers, asserting, "we deem it unjustifiable to call them concentration camps with all the ugly connotations that term implies."197 Having thus bolstered the triggering emergency and downplayed the restrictions, the Supreme Court ruled that Congress and the executive branch acting together could enact the exclusion order as a valid exercise of war power. ${ }^{198}$ The Court did not address the President's power to act

191. See, e.g., Grutter v. Bollinger, 539 U.S. 306, 351 (2003) (Thomas, J., concurring in part and dissenting in part) (modern usage of the "strict scrutiny" doctrine); Adarand Constructors Inc. v. Pena, 515 U.S. 200, 214 (1995) (same).

192. Korematsu v. United States, 323 U.S. 214, 216 (1944).

193. Id. at $217-19$.

194. Id. at 220 .

195. Id. at 221 (asserting that "the only issues framed at the trial related to petitioner's remaining in the prohibited area in violation of the exclusion order").

196. Id.

197. Id. at 223. The Court further opined, "we are dealing specifically with nothing but an exclusion order. To cast this case into outlines of racial prejudice, without reference to the real military dangers which were presented, merely confuses the issue." Id.

198. Id. at 217-18 ("[W]e are unable to conclude that it was beyond the war power of Congress and the Executive to exclude those of Japanese ancestry from the West Coast war area at the time 
unilaterally, having found that Congress explicitly invested the executive with authority to effect the order at issue. ${ }^{199}$

The Court nonetheless preserved some judicial review over the purported bases for the exclusion order. ${ }^{200}$ The test for constitutionality seems to have been whether the war measure bore a definite and close relationship to a legitimate wartime goal. In concluding that the exclusion order was valid, the Court observed that preventing sabotage and espionage was a legitimate wartime objective ${ }^{201}$ to which the order bore a "definite and close relationship." 202 As in Hirabayashi, the Court relied on the conclusion that there were numerous disloyal Japanese Americans, who were impossible to segregate from loyal Japanese Americans. ${ }^{203}$ The Court patently refused to review the larger detention scheme and even cross referenced Ex parte Endo, ${ }^{204}$ stating that it illustrated the difference between the validity of an order to exclude and the validity of a detention order after exclusion had been effected." 205

Justice Roberts, in dissent, vehemently objected to the piecemeal approach adopted by the majority. ${ }^{206}$ He carefully laid out the series of orders that both compelled Korematsu to leave the area of his home and constrained him to that area, operatively giving Korematsu two options only: military detention or criminal incarceration for violating military orders. ${ }^{207}$ Justice Roberts described the order as a "cleverly devised trap

they did.").

199. Id. at 223 ("Congress, reposing its confidence in this time of war in our military leaders-as inevitably it must - determined that they should have the power to [promulgate the regulations].").

200. Id. at $218-19$.

201. Id. at 218 ("[E]xclusion from a threatened area, no less than curfew, has a definite and close relationship to the prevention of espionage and sabotage.").

202. Id.

203. Id. The Court went on to say that its conclusion that the restriction was a valid exercise of war power rebutted Korematsu's assertion that the restriction was an unconstitutional exercise of racial prejudice. $I d$. at 223

204. 323 U.S. 283 (1944) (finding continued detention of Japanese internee Endo unlawful).

205. Korematsu, 323 U.S. at 222 (citation omitted).

206. He characterized Korematsu as a

case of convicting a citizen as a punishment for not submitting to imprisonment in a concentration camp, based on his ancestry, and solely because of his ancestry, without evidence or inquiry concerning his loyalty and good disposition towards the United States.

Id. at 226. (Roberts, J., dissenting).

207. He observed,

The predicament in which the petitioner thus found himself was this: He was forbidden, by Military Order, to leave the zone in which he lived; he was forbidden, by Military Order, after a date fixed, to be found within that zone unless he were in an Assembly Center located in that zone.... [A]n Assembly Center was a euphemism for a prison. Id. at 230 
to accomplish the real purpose of the military authority, which was to lock [Korematsu] up in a concentration camp." ${ }^{208} \mathrm{He}$ further characterized the majority's analysis as "a substitution of an hypothetical case" for the case at hand and observed, "I might agree with the court's disposition of the hypothetical case ... [b]ut the facts above recited, and those set forth in Ex parte Endo, show that exclusion was but a part of an over-all plan for forcible detention.",209

Justice Murphy dissented to the contention that the race-based restrictions were reasonably expedient military orders. ${ }^{210} \mathrm{He}$ argued that the order, which indiscriminately excluded Japanese Americans, bore no rational relation to articulated military goals because it "must rely for its reasonableness upon the assumption that all persons of Japanese ancestry may have a dangerous tendency to commit sabotage and espionage."211 Such judgment, according to Murphy, resulted from an irrational process involving "erroneous assumption[s] of racial guilt rather than bona fide military necessity." 212 Describing how the military orders were based not on fact, but on racist stereotypes and insinuations, Justice Murphy concluded that the Korematsu opinion was a "legalization of racism"213 and "utterly revolting among a free people who have embraced the principles set forth in the Constitution." 214

Justice Jackson's famous dissent stands primarily for a principle of constitutional silence regarding military decision making. Upholding the value of institutional competence, he asserted that jurists are not capable

208. Id. at 232 .

209. Id. (citation omitted). Justice Roberts also objected to the implication of the majority's analysis that even if detention were unconstitutional, Korematsu was nonetheless constrained to submit to the exclusion order and later challenge his detention by way of petition for writ of habeas corpus. He stated, "Again it is a new doctrine of constitutional law that one indicted for disobedience to an unconstitutional statute may not defend on the ground of the invalidity of the statue but must obey it though he knows it is no law." Id. at 233.

210. Justice Murphy's dissent set forth a clear test for determining the limits of military discretion. He asserted that the military restriction must be "reasonably related to a public danger that is so 'immediate, imminent, and impending' as not to admit of delay and not to permit the intervention of ordinary constitutional processes to alleviate the danger." Id. at 234 (Murphy, J., dissenting) (quoting United States v. Russell, 80 U.S. 623, 628 (1871)). Like the majority, Justice Murphy accepted the prevention of invasion through combating sabotage and espionage as a valid wartime goal. Id. at 235. However, he concluded that there was no rational relation between exclusion and preventing espionage. Id. at 236-37. Justice Murphy also criticized the majority's failure to call for a more narrowly tailored program to meet government needs, specifically individual loyalty hearings like the ones afforded to those of German and Italian ancestry. Id. at 241.

211. Id. at 235 .

212. Id. at $235-36$.

213. Id. at 242 .

214. Id. 
of second guessing military commanders' decisions. ${ }^{215}$ Regarding DeWitt's specific choices, Jackson admitted, "I cannot say, from any evidence before me, that the orders of General DeWitt were not reasonably expedient military precautions, nor could I say that they were." 216 Justice Jackson objected to the majority's constitutional stamp of approval on the internment, asserting that "a judicial construction of the due process clause that will sustain this order is a far more subtle blow to liberty than the promulgation of the order itself."217 Acknowledging the inherent problem in his abdication approach, namely that it left the Court no power to remedy military abuses while issues are ripe and deprivations ongoing, ${ }^{218}$ Justice Jackson responded that, "[a] military order, however unconstitutional, is not apt to last longer than the military emergency." 219

\section{Ex parte Endo}

Mitsuye Endo's case ${ }^{220}$ came before the Supreme Court in a quite different procedural posture than Hirabayashi and Korematsu. Endo had complied with all military regulations and reported to the Tule Lake War Relocation Center in Northern California. ${ }^{221}$ By the time the Supreme Court reviewed Endo's petition, originally filed in the Northern District of California, government authorities had moved her to a detention camp in Utah. ${ }^{222}$ Endo's petition alleged that she was "a loyal and law-abiding citizen of the United States, that no charge had been made against her,

215. Id. at 244-45 (Jackson, J., dissenting).

216. Id. at 245 .

217. Id. at 245-46. Justice Frankfurter, in his concurrence, also advocated limiting the role of judicial review in military decision making. He argued that it was not for the Court to approve or disapprove of the basis for any military decision. Rather, the Court's role is at an end once it is determined that the "military orders are "reasonably expedient military precautions' in time of war." $I d$. at 225 (Frankfurter, J., concurring). He stated, "To find that the Constitution does not forbid the military measures now complained of does not carry with it approval of that which Congress and the Executive did. That is their business, not ours." Id.

218. Id. at 245 (Jackson, J., dissenting).

219. Id. at 246. He also observed that in the absence of a judicial check on military discretion, the military must be self-regulating, stating, "The chief restraint upon those who command the physical forces of the country, in the future as in the past, must be their responsibility to the political judgments of their contemporaries and to the moral judgments of history." Id. at 248.

220. Ex parte Endo, 323 U.S. 283 (1944).

221. Id. at 285 .

222. Endo filed a petition for writ of habeas corpus from Tule Lake in July 1942 in the District Court for the Northern District of California, which subsequently denied her petition in July 1943. In August 1943, the denial was appealed to the Ninth Circuit, and shortly thereafter Endo was moved to a detention camp in Utah. The questions of law presented in the petition and record were certified to the Supreme Court on May 8, 1944. Id. 
that she [was] being unlawfully detained, and that she [was] confined in the Relocation Center under armed guard and held there against her will., 223

The Court ultimately resolved Endo's claims through legislative interpretation, rather than constitutional analysis, determining that Endo's "civilian" detention by the War Relocation Authority had not been authorized by Congress and the President. ${ }^{224}$ In an effort to avoid deciding constitutional and law-of-war issues, the Court characterized the War Relocation Authority as a civilian agency and concluded that "no questions of military law are involved." 225 In holding that the War Relocation Authority had no power to detain a concededly loyal citizen, the Court engaged in an in-depth examination of the executive orders and legislation underlying the Japanese evacuation program. The Court stated, "We approach the construction of Executive Order No. 9066 as we would approach the construction of legislation in this field. That Executive Order must indeed be considered along with the Act of March 21, 1942, which ratified and confirmed it."226

The Court opined that the express purpose of both the Act of March 21, 1942, and Executive Order 9066 was to protect against espionage and sabotage. In effectuating this goal, both directives called for the administration of curfews and removal. ${ }^{227}$ The Court noted, however, that "[n]either the Act nor the orders use the language of detention.",228 Moreover, the Court observed that, unlike the curfew order involved in Hirabayashi, the legislative history of the Act was silent on detention and "that silence may have special significance in view of the fact that detention in Relocation Centers was no part of the original program of evacuation."229 The Court, however, narrowed its holding to the sole

223. Id. at 294.

224. Id. at $298-302$.

225. Id. at 298 .

226. Id. The Court then applied the canon of avoidance favoring the "interpretation of legislation which gives it the greater chance of surviving the test of constitutionality." Id. at 299. The Court was careful to impute to lawmakers the greatest possible regard for citizens' liberties, stating, "We must assume, when asked to find implied powers in a grant of legislative or executive authority, that the law makers intended to place no greater restraint on the citizen than was clearly and unmistakably indicated by the language they used." Id. at 300 .

227. Id.

228. Id.

229. Id. at 301. The government had argued that Congress ratified the detention scheme through its appropriation of money to the program, and it presented several congressional hearings and reports prior to appropriations in which Congress was apprised of the detention programs. Id. at 304 n.24. The Court declined to accept this information as indicative of express congressional intent, asserting that "[w]e can hardly deduce such a purpose here where a lump appropriation was made for the overall program of the Authority." Id. 
issue of the continued incarceration of a concededly loyal citizen, indicating that the War Relocation Authority might possess other detention powers. ${ }^{230}$

The Court also addressed the procedural issue of whether the Northern District of California retained jurisdiction over Endo's case, given that Endo had been moved to Utah. Answering in the affirmative, the Court did not suggest that the government had moved Endo to avoid the proceedings, ${ }^{231}$ but rather found continued jurisdiction proper because of the presence in the district court's jurisdiction of those "responsible for the detention of appellant and who would be an appropriate respondent." 232 The Court noted that the presence of any official of the War Relocation Authority in the district court's jurisdiction would confer jurisdiction because such a person would be able to produce "the corpus of appellant." 233 The Court was unmoved by the objection that no respondent had been served, observing that "[a] cause exists in that state of the proceedings and an appeal lies from denial of a writ without the appearance of a respondent., ${ }^{, 23}$

\section{B. The Terrorism Cases}

\section{Rumsfeld v. Padilla}

On May 8, 2002, authorities arrested Jose Padilla, the suspected "dirty bomber," 235 in Chicago pursuant to a material-witness warrant issued by the Southern District of New York in connection with the 9/11 grand jury investigation. ${ }^{236}$ They transported Padilla to New York, placed him in a maximum-security prison, and brought him before Chief Judge Mukasey, who appointed Donna R. Newman as his attorney. ${ }^{237}$ Newman moved the Court to release Padilla from detention, and the

\footnotetext{
230. Id. at 301 .

231. Id. at $306-07$.

232. Id. at 304 .

233. Id. at 305 .

234. Id.

235. Authorities believed Padilla had conspired to detonate a "radiological dispersal device" in the United States. See infra note 245 (discussing the Mobbs Declaration).

236. Padilla ex rel. Newman v. Bush, 233 F. Supp. 2d 564, 568-69 (S.D.N.Y. 2002) aff'd in part, rev'd in part sub nom. Padilla v. Rumsfeld, 352 F.3d 695 (2d Cir. 2003), rev'd, 542 U.S. 426 (2004). At the time of his arrest, Padilla had just arrived on a flight from Pakistan. Id. at 573. He carried no weapons or contraband of any type. Brief of Respondent at 24, Rumsfeld v. Padilla, 542 U.S. 426 (2004) (No. 03-1027).

237. Padilla, 233 F. Supp. $2 \mathrm{~d}$ at 571.
} 
motion was set for conference on June 11, 2002. ${ }^{238}$ On June 9, 2002, President Bush issued an executive order designating Padilla an unlawful enemy combatant and directing Secretary Rumsfeld to hold him in military detention. ${ }^{239}$ Padilla was transferred to a military jail in South Carolina and held incommunicado. ${ }^{240}$ To date, Padilla remains incarcerated. $^{241}$

On June 11, Newman filed a habeas corpus petition in New York on Padilla's behalf as a "next friend."242 On December 4, 2002, the district court issued a lengthy opinion concluding that the government possessed the power to detain Padilla militarily, based on the theory that he was an enemy combatant. ${ }^{243}$ The court further held that the President, acting alone, could exercise such authority. ${ }^{244}$ Over the government's objections, ${ }^{245}$ however, the court concluded that Padilla had the right to

\footnotetext{
238. Id.

239. Id.

240. Id. at $571-72$.

241. See infra notes 273-77 and accompanying text (discussing Padilla's current status).
}

242. 28 U.S.C. $§ 2242$ (2000) provides that a claim being asserted on behalf of another "shall be in writing signed and verified by the person for whose relief it is intended or by someone acting in his behalf." According to the Supreme Court, there are two prerequisites for "next friend" standing: (1) "“an adequate explanation - such as inaccessibility, mental incompetence, or other disabilitywhy the real party in interest cannot appear on his own behalf to prosecute the action,"” and (2) "some significant relationship [between the next friend and] the real party in interest." Padilla, 233 F. Supp. 2d at 575 (quoting Whitmore v. Arkansas, 495 U.S. 149, 163-64 (1990)).

243. Padilla, 233 F. Supp. $2 \mathrm{~d}$ at 589.

244. The court observed, "I read the Prize Cases to stand for the proposition that the President has independent authority to repel aggressive acts by third parties even without specific congressional authorization, and courts may not review the level of force selected." Id. at 589 (quoting Campbell v. Clinton, 203 F.3d 19, 27 (D.C. Cir. 2000) (Silberman, J., concurring)). The court ruled that, in any case, the Authorization for Use of Military Force, see infra note 259, was sufficient congressional approval of the action. $I d$. at 590 .

245. The government had argued that a conclusory, nine-paragraph statement by Defense Department employee Michael Mobbs, who had no direct knowledge of events, was sufficient standing alone to justify Padilla's classification. Id. at 603-04. The basic substance of the Mobbs Declaration follows:

As part of my official duties, I have reviewed government records ....

... While in Afghanistan in 2001, Padilla met with senior Usama Bin Laden lieutenant Abu Zubaydah.... Zubaydah directed Padilla and his associate to travel to Pakistan for training from Al Qaeda operatives in wiring explosives.

....

... Padilla's discussions with Zubaydah specifically included the plan of Padilla and his associate to build and detonate a "radiological dispersal device" (also known as a "dirty bomb") within the United States, possibly in Washington, DC. The plan included stealing radioactive material for the bomb within the United States. The "dirty bomb" plan of Padilla and his associate allegedly was still in the initial planning stages, and there was no specific time set for the operation to occur.

....

... Although one confidential source stated that he did not believe that Padilla was a 
challenge his classification as an enemy combatant by pursuing his habeas petition, ${ }^{246}$ and to engage in limited communications with counsel in pursuance of the petition. ${ }^{247}$ The court set up a standard of judicial review highly deferential to the government, stating that it would uphold the designation if "the President had some evidence to support his finding that Padilla was an enemy combatant." ${ }^{, 248}$ The district court was unmoved by Padilla's contention that because the War on Terror might never end, the court had essentially approved indefinite detention. The court opined that "insofar as [Padilla's] argument assumes that indefinite confinement of one not convicted of a crime is per se unconstitutional, that assumption is simply wrong." 249

On appeal, the Second Circuit issued an order releasing Padilla from military detention and holding that the President did not have authority to detain Padilla as an unlawful combatant. ${ }^{250}$ The court observed at the outset that the "President's power 'must stem either from an act of Congress or from the Constitution itself." 251 The court analyzed Padilla's case under the legal framework set forth in Justice Jackson's concurrence in Youngstown Sheet \& Tube Co. v. Sawyer. ${ }^{252}$ Justice Jackson had articulated three categories of presidential wartime power: (1) when the President acts pursuant to an express or implied

"member" of Al Qaeda, Padilla has had significant and extended contacts with senior $\mathrm{Al}$ Qaeda members and operatives.

Declaration of Michael H. Mobbs, Special Advisor to the Under Secretary of Defense for Policy (Aug. 27, 2002), available at http://www.cnss.org/Mobbs\%20Declaration.pdf. The court rejected the government's argument and refused to allow the government to proceed unchallenged on the "gossamer speculation" presented in the Mobbs Declaration. Padilla, 233 F. Supp. 2d at 604.

246. Padilla, 233 F. Supp. 2d at 599-600.

247. Specifically, the court held that Padilla had a right to confer with counsel but only "under conditions that will minimize the likelihood that he [could] use his lawyers as unwilling intermediaries for the transmission of information to others." Id. at 610 .

248. Id. at 570 .

249. Id. at 591. The judge then ordered the parties to consult and make appropriate arrangements for Padilla to meet with his counsel and report to the court by December 30, 2002. Id. at 610. By that date, the government had not allowed Padilla to meet with counsel nor had it agreed to conditions of such a meeting. See Padilla ex rel. Newman v. Rumsfeld, 243 F. Supp. 2d 42, $43-$ 45 (S.D.N.Y. 2003), aff'd in part, rev'd in part sub nom. Padilla v. Rumsfeld, 352 F.3d 695 (2d Cir. 2003), rev'd, 542 U.S. 426 (2004) (describing procedural history delaying Padilla's opportunity to meet with counsel). Instead, the government filed an untimely motion to reconsider. See id. at 45 (stating that "the time for a motion to ... reconsider had expired"). After addressing the motion substantively, the Court declined to reconsider its position and firmly stated, "Lest any confusion remain, this is not a suggestion or a request that Padilla be permitted to consult with counsel, and it is certainly not an invitation to conduct a further 'dialogue' about whether he will be permitted to do so. It is a ruling - a determination - that he will be permitted to do so." Id. at 57.

250. Padilla, 352 F.3d at 724 .

251. Id. at 711 (quoting Youngstown Sheet \& Tube Co. v. Sawyer, 343 U.S. 579,585 (1952)).

252. Id. 
congressional authorization, such that "his authority is at its maximum, for it includes all that he possesses in his own right plus all that Congress can delegate;",253 (2) when the President acts without congressional authorization, and "he can only rely upon his own independent powers," such that "his power is at its lowest ebb, for then he can rely only upon his own constitutional powers minus any constitutional powers of Congress over the matter." 255

The Second Circuit placed Padilla's detention in the third category because the President had acted in contravention of the 1971 Nondetention Act, which provides, "No citizen shall be imprisoned or otherwise detained by the United States except pursuant to an Act of Congress." 256 The court asserted that Padilla's detention was not an inherent power of the President stemming from his status as Commander in Chief that could overcome the congressional prohibition. ${ }^{257}$ The court recognized, however, that the political branches, acting together, might possess the power to detain Padilla. ${ }^{258}$ The government had urged that Congress's Joint Resolution Authorizing the Use of Military Force (AUMF), which passed in the days after $9 / 11$ and authorized the President to use "all necessary and appropriate force" against "nations,

\footnotetext{
253. Youngstown, 343 U.S. at 635 (Jackson, J., dissenting).

254. Id. at 637 .
}

255. Id.

256. Nondetention Act, Pub. L. No. 92-128, 85 Stat. 347, 347 (1971) (codified as amended at 18 U.S.C. § 4001(a) (2000)). The Nondetention Act, as amended in 1971, repealed the Emergency Detention Act of 1950, in part as a response to the horrors of the internment. The House Report on the Amendments states,

[G]roups of Japanese-American citizens regard the [Emergency Detention Act] as permitting a recurrence of the round ups which resulted in the detention of Americans of Japanese ancestry in 1941 and subsequently during World War II. They urge that the Act should be repealed.

H. R. REP. No. 92-116, at 1436 (1971).

257. Padilla, 352 F.3d at 721 . The court drew a sharp distinction between inherent presidential power to regulate foreign policy and detain combatants on the battlefield and the President's power to affect domestic policy, stating that "the President, acting alone, possesses no inherent constitutional authority to detain American citizens seized within the United States, away from a zone of combat, as enemy combatants." Id.

258. The court stated, "while Congress - otherwise acting consistently with the Constitutionmay have the power to authorize the detention of United States citizens under the circumstances of Padilla's case, the President, acting alone, does not." Id. at 715. The court thus distinguished Padilla's case from Ex parte Quirin, a case in which a U.S. citizen acting as a Nazi spy was arrested on U.S. soil and tried by military tribunal, observing that Congress had specifically authorized Quirin's military tribunal. 317 U.S. 1, 26-28 (1942). The Second Circuit further observed that when the Supreme Court decided Quirin, Congress had not yet passed the Nondetention Act. Padilla, 352 F.3d at 716. 
organizations, or persons" associated with the $9 / 11$ attacks, ${ }^{259}$ was congressional authorization of Padilla's detention. ${ }^{260}$ The court, however, rejected the AUMF as a sufficient congressional mandate that could overcome the clear language of the Nondetention Act. ${ }^{261}$ Subsequently, the Second Circuit ordered Padilla's release, but stayed the order pending resolution of the case by the Supreme Court.

The Supreme Court, in an ultimate exercise of judicial avoidance, declined to rule on the merits of Padilla's claims and instead dismissed his petition on the grounds that it named an improper respondent, Secretary Rumsfeld, and was filed in an improper jurisdiction, New York. ${ }^{262}$ Asserting that the proper respondent was the commander of the South Carolina brig and the proper jurisdiction was South Carolina, the Court stated, "Only in an exceptional case may a court deviate from those basic rules to hear a habeas petition filed against some person other than the immediate custodian of the prisoner, or in some court other than the one in whose territory the custodian may be found."263 The Court held that Padilla's case was not exceptional because Newman had filed the petition in New York after Padilla had been moved, and thus she could have filed in South Carolina. ${ }^{264}$

The Court also rejected the contention, accepted by both courts below, that Secretary Rumsfeld was a proper respondent given his familiarity with Padilla's case and the control he asserted over Padilla's detention. Instead, the Court favored the "default rule" that "the proper respondent is the warden of the facility where the prisoner is being held, not the Attorney General or some other remote supervisory official."265 The Court distinguished Padilla's case from Endo by observing that Endo had initially filed her petition in the place where she was detained,

259. Authorization of Use of Military Force, Pub. L. No. 107-40, § 2(a), 115 Stat. 224, 224 (2001).

260. Padilla, 352 F.3d at 724 .

261. The court considered and rejected the government's contention that the Nondetention Act was never meant to apply to military detentions. The court noted that the resolution must be interpreted to assume "'that the law makers intended to place no greater restraint on the citizen than was clearly and unmistakably indicated by the language they used." Padilla, 352 F.3d at 723 (quoting Ex parte Endo, 323 U.S. 283, 300 (1944)). The court also rejected the contention that 10 U.S.C. $\$ 965(5)$, which appropriated funding to pay for persons detained pursuant to executive order, authorized the detention of Padilla. Id. at 724 .

262. Rumsfeld v. Padilla, 542 U.S. 426, 446-47 (2004).

263. Id. at 454. To address the many exceptions to strict filing rules for habeas petitions, the Court characterized filing rules as analogous to venue or personal jurisdiction and thus waivable by the government or subjected to certain equitable exceptions. Id. at 453.

264. Id. at 454-55.

265. Id. at 435 . 
whereas Newman had filed in New York after Padilla had been moved to South Carolina. ${ }^{266}$

Justice Stevens's dissent chastised the majority for its judicial abdication, stating, "[t]he petition for a writ of habeas corpus filed in this case raises questions of profound importance to the Nation. The arguments set forth by the Court do not justify avoidance of our duty to answer those questions." ${ }^{267}$ Advocating in favor of finding jurisdiction, Justice Stevens argued for a more "functional approach" to jurisdiction. ${ }^{268} \mathrm{He}$ asserted that Secretary Rumsfeld was a proper respondent because of his direct involvement and that jurisdiction was proper in the Southern District of New York at the time the petition was filed. ${ }^{269}$ Justice Stevens was not concerned that Newman had filed the motion in New York the day after Padilla had been moved, given that the government had never informed Newman of the move and that she had heard about it only from press reports. ${ }^{270}$ In the end, Justice Stevens called the majority's characterization of Padilla's petition "disingenuous at best" and described the case as "singular not only because it calls into question decisions made by the Secretary himself, but also because those decisions have created a unique and unprecedented threat to the freedom of every American citizen." 271 Stevens concluded, "At stake in this case is nothing less than the essence of a free society. Even more important than the method of selecting the people's rulers and their successors is

266. The Court noted that "the Southern District never acquired jurisdiction over Padilla's petition." The Court concluded that "Endo stands for the important but limited proposition that when the Government moves a habeas petitioner after she properly files a petition naming her immediate custodian, the District Court retains jurisdiction and may direct the writ to any respondent within its jurisdiction who has legal authority to effectuate the prisoner's release." Id. at 441. The Court further held that even if jurisdiction is sometimes proper when the prisoner is outside the territorial limits of the issuing court, as in Endo, the custodian must nonetheless be within the issuing court's territorial jurisdiction. The Court observed that it would encourage forum shopping to allow prisoners to sue government subordinates in any district court in the nation. Id. at 447.

267. Id. at 455 (Stevens, J., dissenting).

268. Id. at 461 .

269. Id. at 458-59 n.3. Justice Stevens saw no difference between Padilla's situation and Endo's. Id. at 462 n.5.

270. Id. at 458-59 n.3. Justice Stevens emphasized that just two days before the scheduled hearing on the criminal motions on June 11,2002, the government informed the court ex parte that it was transferring Padilla to military custody in South Carolina. The Court further described how Newman only discovered the change of custody through the press, not the government, on June 10, 2002, the day after which she filed the habeas corpus motion. Justice Stevens observed that at the time Padilla was being handcuffed by Defense Department officials in New York, unbeknownst to Newman, Secretary Rumsfeld was the proper respondent and New York was the proper jurisdiction. He then reasoned that denying jurisdiction on the narrow ground of the one-day delay in filing the habeas corpus motion was tantamount to permitting "the Government to obtain a tactical advantage as a consequence of an ex parte proceeding." Id. at 459.

271. Id. at 461 . 
the character of the constraints imposed on the Executive by the rule of law." 272

Padilla's case was transferred to the District of South Carolina, pursuant to the Supreme Court's directive. On February 28, 2005, the district court in South Carolina held that Padilla's detention was unconstitutional and gave the executive forty-five days to charge Padilla criminally or release him. ${ }^{273}$ The government appealed, and on September 9, 2005, the Fourth Circuit reversed the district court. Relying on the Supreme Court ruling in Hamdi, the court held that the President possessed constitutional authority to detain Padilla as an enemy combatant. $^{274}$ The Supreme Court has yet to grant certiorari to review the Fourth Circuit's decision. ${ }^{275}$ On November 17, 2005, the government filed an indictment in the Southern District of Florida charging Padilla with conspiracy to murder, kidnap, and maim persons in a foreign country, conspiracy to provide material support to a terrorist organization, and providing material support to a terrorist organization. ${ }^{276}$ Padilla was transferred to the Southern District of Florida, where on February 17, 2006, the district court denied his bail request. Padilla remains incarcerated pending his criminal trial. ${ }^{277}$

\section{Hamdi v. Rumsfeld}

Unlike Padilla, Yaser Hamdi was taken into U.S. custody in Afghanistan during ongoing hostilities. ${ }^{278}$ Of course, Hamdi's advocates assert that he was a noncombatant unlawfully captured by the Northern Alliance. ${ }^{279}$ Originally, authorities detained Hamdi at Guantanamo, but,

272. Id. at 465 .

273. Padilla v. Hanft, 389 F. Supp. 2d 678, 692 (D.S.C. 2005), rev'd, 423 F.3d 386 (4th Cir. 2005)

274. Padilla v. Hanft, 423 F.3d 386 (4th Cir. 2005). The Court asserted that the Supreme Court decision in Hamdi compelled the conclusion that the President had such power and dismissed the language in Hamdi confining the holding to "narrow issue" of Hamdi's circumstances. Id. at 39394. The Fourth Circuit held that the "actual reasoning" in Hamdi "simply does not admit of a distinction between an enemy combatant captured abroad and detained in the United States." Id. at 393.

275. See Hanft v. Padilla, 126 S.Ct. 978 (2006) (stating that the "Court will consider the pending petition for certiorari in due course").

276. United States v. Hassoun, Case No. 04-60001-CR-Cooke (Nov. 17, 2005).

277. See Phil Hirschkorn, Former 'Enemy Combatant' Denied Bail, CNN.COM, Feb. 17, 2006, http://www.cnn.com/2006/LAW/02/17/padilla.hearing/index.html.

278. Hamdi was turned over to U.S. forces by members of the Northern Alliance. Hamdi v. Rumsfeld, 243 F. Supp. 2d 527, 529 (E.D. Va. 2002), rev'd, 316 F.3d 450 (4th Cir. 2003), vacated, 542 U.S. 507 (2004).

279. Hamdi's contention appears to be vindicated by the subsequent actions of the Bush 
upon learning of his U.S. citizenship, transferred him to a military jail in Virginia, where he remained in military custody for more than two years. In June 2002, Hamdi's father filed a habeas corpus petition as a next friend. ${ }^{280}$ The district court appointed a public defender to the case and ordered the government to give Hamdi access to counsel. The government appealed to the Fourth Circuit, urging reversal on grounds that Hamdi's access to counsel posed security risks and that "courts may not second-guess the military's determination that an individual is an enemy combatant and should be detained as such." 281 The Fourth Circuit reversed and remanded for further inquiry on the counsel issue, asserting that Hamdi's case was different from a "garden-variety" criminal case. ${ }^{282}$ Specifically, the court directed the district court to consider "what effect petitioner's unmonitored access to counsel might have upon the government's ongoing gathering of intelligence" and "to what extent federal courts are permitted to review military judgments of combatant status." 283

While this issue was pending in the district court, the government submitted the sealed "Mobbs Declaration," a conclusory, nine-paragraph document by defense department employee Michael H. Mobbs, and asserted that the declaration, standing alone, provided a sufficient basis for Hamdi's classification and detention as an enemy combatant. ${ }^{284}$ The

\footnotetext{
Administration. On October 10, 2004, the Bush Administration released Hamdi in exchange for a renunciation of his U.S. citizenship and with the condition that he not return for five years. Phil Hirschkorn, Saudi Once Held by U.S. Returns Home, CNN.COM, Oct. 11, 2004, http://www.cnn.com/ 2004/WORLD/meast/10/11/hamdi/. The United States almost certainly would not have taken this course of action had there been any evidence that Hamdi engaged in active combat against U.S. forces. Simultaneously, the U.S. government is trying Guantanamo detainees in military tribunals as military criminals for fighting in Afghanistan. See supra note 77. It is highly unlikely that Hamdi received a "free pass," especially given the political pressure on the Administration to justify his two-and-a-half year, process-less detention. Thus, it seems as if Hamdi's detention is further support for David Cole's argument that "there are no mass preventive detention success stories in our history." Cole, supra note 153, at 1755.

280. See supra note 242 , for discussion of next-friend status. Initially, the public defender had filed the habeas corpus action as a next friend. The Fourth Circuit ultimately dismissed that petition, ruling that the relationship between the defender and Hamdi was not significant enough to establish next-friend status. Hamdi v. Rumsfeld, 294 F.3d 598, 607 (4th Cir. 2002).

281. Hamdi v. Rumsfeld, 296 F.3d 278, 283 (4th Cir. 2002) (quoting government brief).

282. Id. at 282-83.

283. Id. at 282. The court, however, rejected as "premature" the government's request to dismiss the petition outright. Id. at 283.

284. Like the Mobbs Declaration in Padilla, the Mobbs Declaration in Hamdi was conclusive and vague. It offered the following statements relating to Hamdi:

Yaser Esam Hamdi traveled to Afghanistan in approximately July or August of 2001. He affiliated with a Taliban military unit and received weapons training. Hamdi remained with his Taliban unit following the attacks of September 11 and after the United States began military operations against the al Qaeda and Taliban on October 7, 2001.
} 
district court ruled that the Mobbs Declaration was not a proper basis for the detention. The court acknowledged the importance of deference to the political branches on matters of national security, but found that due process required some meaningful judicial review of the detention of a U.S. citizen, ${ }^{285}$ and that the Mobbs Declaration fell "far short of even . . . minimal criteria for judicial review." 286

The Fourth Circuit once again reversed. The court began by rejecting the contention that U.S. citizens could not be detained as unlawful combatants, observing that the President could detain Hamdi pursuant to his Article II powers as Commander in Chief. ${ }^{287}$ The court further ruled that the Nondetention Act was no bar to the President's actions because the AUMF had implicitly authorized the detention of U.S. citizens engaged in enemy military activities abroad. ${ }^{288}$ The court was not persuaded by Hamdi's argument that continued detention was unjustified because hostilities in Afghanistan had ended and instead observed that detention was valid so long as "American troops are still on the ground in Afghanistan, dismantling the terrorist infrastructure in the very country where Hamdi was captured."289

... In late 2001, Northern Alliance forces were engaged in battle with the Taliban. During this time, Hamdi's Taliban unit surrendered to Northern Alliance forces... $[T]$ he Northern Alliance transferred Hamdi to a prison at Sheberghan, Afghanistan ....

.. While in the Northern Alliance prison at Sheberghan, Hamdi was interviewed by a U.S. interrogation team. He identified himself as a Saudi citizen who had been born in the United States and who entered Afghanistan the previous summer to train with and, if necessary, fight for the Taliban. Hamdi spoke English.

Declaration of Michael H. Mobbs, Special Advisor to the Under Secretary of Defense for Policy (July 24, 2002), available at http://www.cbsnews.com/htdocs/pdf/hamdimobbs2.pdf.

285. The court opined that, at a minimum, meaningful judicial review would entail a determination of (1) whether the detainee's classification was made by someone with appropriate authority; (2) whether the method of classification was procedurally sound; (3) the basis for the government's determination that detention without access to counsel served national security; and (4) whether a different process was required by the Geneva Convention or the Joint Services Regulation. Hamdi v. Rumsfeld, 243 F. Supp. 2d 527, 532-33 (E.D. Va. 2002), rev'd, 316 F.3d 450 (4th Cir. 2003), vacated, 542 U.S. 507 (2004).

286. Critically examining the declaration, the court concluded that the declaration did not provide even minimal justification for detention because the declaration neither specifically articulated Mobbs's expertise on or authority over enemy combatants, nor set forth any facts supporting the conclusion that Hamdi was a combatant, save for the fact that he was captured by the Northern Alliance and had previously trained with the Taliban. Id. at 533. The court concluded, "While the Executive may very well be correct that Hamdi is an enemy combatant whose rights have not been violated, the Court is unwilling, on the sparse facts before it to find so at this time on the basis of the Mobbs Declaration." Id. at 536.

287. Hamdi, 316 F.3d at 473.

288. Id. at 467.

289. Id. at 476 . 
The court carved out a limited role for judicial review, holding that executive decisions should not be set aside by the courts "without the clear conviction that they are in conflict with the Constitution or laws of Congress constitutionally enacted." ${ }^{290}$ Thus, the only issue appropriate for judicial review was whether the President had acted "pursuant to the war powers." 291 Examining the Mobbs Declaration, the court opined that "Hamdi was indisputably seized in an active combat zone" and that this fact alone was sufficient to establish that President Bush had exercised legitimate war power. ${ }^{292}$ The court accordingly dismissed Hamdi's petition.

On June 28, 2004, the Supreme Court issued an opinion reversing and remanding. The plurality opinion, authored by Justice O'Connor, held that the government possessed the authority to detain U.S. citizens classified as enemy combatants, but that the courts retained ability to review the bases for such classifications. ${ }^{293}$ The Court disapproved of the Fourth Circuit's formulation of minimal judicial review and instead endorsed a fuller process of individualized review. ${ }^{294}$

The first substantive issue addressed by the Court was the scope of the government's detention authority. The government had asserted that the President, acting alone, could detain enemy combatants and, in the alternative, that Congress had authorized Hamdi's detention by the AUMF. ${ }^{295}$ The Court agreed that Congress had authorized Hamdi's detention and that together the political branches possessed authority to detain Hamdi militarily. ${ }^{296}$ The Court thus declined to address whether the President possessed such power unilaterally. The Court opined that pursuant to the "laws of war," a nation engaged in war may detain enemy fighters for the duration of the conflict to prevent them from rejoining the foreign army. ${ }^{297}$ The Court, however, gave little guidance as to what constituted a state of war or why Hamdi should be treated like any

290. Id. at 474. The court relied for this proposition on Ex parte Quirin, a World War II case that justified military detention of a U.S. citizen who committed espionage for Germany. 317 U.S. 1 (1942); see infra notes 391-415 and accompanying text for further discussion of Quirin.

291. Id. at 472 .

292. Id. at 473. The Fourth Circuit did, however, limit its holding to the specific facts of Hamdi's arrest and detention, noting that it had "no occasion, for example, to address the designation as an enemy combatant of an American citizen captured on American soil or the role that counsel might play in such a proceeding." Id. at 465.

293. Hamdi v. Rumsfeld, 542 U.S. 507 (2004).

294. Id. at 526 .

295. Id. at 517.

296. Id. at 521

297. The opinion indicates that Hamdi's detention is justified by "law of war" principles as set forth by various treatises and the Quirin opinion. Id. at 523, 531. 
foreign fighter. ${ }^{298}$ O'Connor acknowledged that certain factual circumstances might test the limit of what constituted a state of war, but nonetheless concluded, "that is not the situation we face as of this date." ${ }^{299}$ O'Connor, like the Fourth Circuit, seems to have endorsed a notion that military detention power can be exercised whenever U.S. troops are engaged in conflict by justifying Hamdi's continued detention with the existence of "active combat operations" in Afghanistan. ${ }^{300}$

The Court more squarely addressed the issue of congressional authorization for the detention, holding that the AUMF was an express endorsement of Hamdi's detention. ${ }^{301}$ The Court reasoned that because of the universality of the law of war, which includes the detention of fighters, Congress must have intended the President to have the power to detain U.S. citizen enemy combatants when it authorized the use of "necessary and appropriate force" against those associated with 9/11. ${ }^{302}$ This imputed knowledge of the law of war was the only interpretive technique the Court used to determine congressional intent. ${ }^{303}$ Moreover, the Court glossed over the question of whether history was so unequivocally clear that "appropriate force" always includes the military detention of citizens, such that Congress's authorization of "appropriate force" unambiguously approves military detention of citizens. ${ }^{304}$

The Court then concentrated on the appropriate process for judicial oversight of the detention. The plurality dismissed outright the

298. While definitively permitting the government to detain citizens, the Court attempted to narrow the scope of this power by defining an "enemy combatant" as a person who "was part of or supporting forces hostile to the United States or coalition partners" and "engaged in an armed conflict against the United States." Id. at 516 (internal quotations omitted). At first blush, this definition seems to limit the world of possible enemy combatants to those who actively fight against U.S. troops on the battlefield. The "engaged in armed conflict" prong, however, could easily be extended to cases of suspected espionage, stepping dangerously close to the logic behind detaining the Japanese. Indeed, the plurality relied extensively on Quirin, which defines "enemy combatant" in terms of domestic espionage rather than foreign battle. Id. at 522. Furthermore, the Court explicitly left to lower courts the obligation to establish the parameters of the enemy combatant category, observing that "[t]he permissible bounds of the category will be defined by the lower courts as subsequent cases are presented to them." Id. at 522 n.1. The Fourth Circuit subsequently took up this invitation as an opportunity to expand the notion of enemy combatant to encompass people who bear little resemblance to fighters captured on a foreign battlefied. Padilla v. Hanft, 423 F.3d 386, 392 (4th Cir. 2005). The court relied on information that Padilla was somewhere in Afghanistan trying escape to Pakistan during the U.S. invasion and likely armed to conclude that he fit into the definition of an "enemy combatant." Id.

299. Hamdi, 542 U.S. at 521.

300. Id.

301. Id.

302. Id.

303. See id. O'Connor neither examined the plain language nor legislative history of the AUMF to conclude that the AUMF constituted explicit congressional approval of U.S. citizen detention.

304. Id. at 518 . 
contention that courts could never review military decision making, ${ }^{305}$ citing Justice Murphy's Korematsu dissent for the proposition that a "'military claim must subject itself to the judicial process of having its reasonableness determined and its conflicts with other interests reconciled.",306 Denying the government's assertion that judicial review should be limited to bases for the broader detention scheme, the Court ruled that Hamdi was entitled to individualized process. ${ }^{307}$ Applying the due process test from Mathews $v$. Eldridge, ${ }^{308}$ the Court balanced Hamdi's private interests against the government's interests. The Court weighed Hamdi's fundamental liberty interest in freedom from involuntary confinement against the asserted government interest of ensuring that captured combatants not return to fight with the enemy, ${ }^{309}$ also taking into account the "practical difficulties" of government compliance with procedural requirements. ${ }^{310}$ The Court determined that due process required the government to give an alleged enemy combatant notice of the factual basis for his classification and a fair opportunity to rebut the government's factual averments in front of a neutral decision maker. ${ }^{311}$ Because of administrative burdens, however, the government would enjoy a rebuttable presumption of accuracy in the classification and the ability to rely on hearsay evidence. ${ }^{312}$ Further, the government could establish its case with information as sparse as that contained in the Mobbs Declaration. ${ }^{313}$

In a surprising political turn, Justice Scalia authored a dissent squarely rejecting that the government may detain U.S. citizens on U.S. soil as enemy combatants. Justice Scalia argued that the Suspension Clause of the Constitution ${ }^{314}$ makes clear that absent a congressional suspension of the writ of habeas corpus, the government has no authority

305. Id. at 536 .

306. Id. (quoting Korematsu v. United States, 323 U.S. 214, 233-34 (1944) (Murphy, J., dissenting)). The Court further noted that all parties agreed that, at the very least, the bare habeas corpus process was available to Hamdi and that "the person detained may, under oath, deny any of the facts set forth in the return or allege any other material facts." Id. at 525.

307. Id. at 528-29.

308. 424 U.S. 319 (1976).

309. Hamdi, 542 U.S. at 531-32.

310. Id. at 531 .

311. Id. at 533 .

312. Id. at 533-34.

313. Even after the Court's declaration of the proper process for determining whether the government's classification of a citizen as an unlawful combatant passes judicial muster, serious questions remain. For example, the opinion is silent as to how much and what type of evidence the detainee must present to rebut the presumption in favor of the government.

314. U.S. CONST., art. I, $\S 9$, cl. 2 ("The Privilege of the Writ of Habeas Corpus shall not be suspended, unless when in Cases of Rebellion or Invasion the public Safety may require it."). 
to detain its own citizens outside of the criminal process. ${ }^{315}$ Surveying the legal history of detention, Scalia concluded that the Framers intended normal criminal procedures to apply to all citizens, except when great exigency rendered normal judicial processes unavailable. ${ }^{316}$

Responding to the contention that the law of war permits the government to detain enemies to prevent them from rejoining hostile forces, Scalia argued that the Constitution provides another way to prevent citizens from rejoining the enemy, namely, prosecution for treason. ${ }^{317} \mathrm{He}$ asserted that while it may be the normal wartime practice to detain foreign nationals as prisoners of war, the normal practice regarding U.S. citizens who aid the enemy is criminal prosecution, rather than military detention and release at the end of conflict. ${ }^{318}$ As to concerns over criminal procedures interfering with war making, Scalia responded that when military exigencies render traditional process impracticable, the legislature has the constitutional power to suspend normal judicial process. ${ }^{319}$

Justice Scalia also criticized the plurality's interpretation of the AUMF as a congressional authorization of Hamdi's detention. He noted that the Court's interpretation conflicted with the interpretive canon that statutes should be construed to avoid grave constitutional concerns. ${ }^{320}$ He further argued that the AUMF did not possess the clarity of language to overcome the Nondetention Act's clear prescription that U.S. citizens may not be detained except through an Act of Congress. ${ }^{321}$

315. Hamdi, 542 U.S. at 554-56 (Scalia, J., dissenting).

316. Id. at 561. He noted that, in the absence of suspension, the Court had historically sanctioned noncriminal detention in only two scenarios - civil commitment of the mentally ill and temporary detention for quarantine. Id. at 556.

317. Id. at 557 .

318. Id. at 558-61.

319. Id. at 561. Justice Scalia patently dismissed the idea that the AUMF was a congressional suspension of the writ. Id. at 574. He also criticized the plurality's reliance on Quirin, characterizing Quirin as an improper departure from the holding in Ex Parte Milligan, 71 U.S. 2 (1866), a civil war case in which the Supreme Court deprived the government power to try citizens militarily absent suspension of the writ. Id. at 570. See also infra note 429 and accompanying text (further explaining the Milligan opinion). He also distinguished Quirin from Hamdi by observing that the Nazi spy in Quirin, unlike Hamdi, was an "admitted enemy invader." Hamdi, 542 U.S. at 571 (Scalia, J., dissenting).

320. Id. at 574 (citing Edward J. DeBartolo Corp. v. Florida Gulf Coast Bldg. \& Constr. Trades Council, 485 U.S. 568, 575 (1988)).

321. Id. 


\section{A JURISPRUDENTIAL COMPARISON OF THE JAPANESE INTERNMENT AND TERRORISM DETENTION CASES: HAVE WE PROGRESSED?}

There is no denying that the result of the Supreme Court rulings in Hamdi and Padilla is a mixed bag. On one hand, neither decision grants unqualified and absolute authority to the executive to classify citizens as enemy combatants and detain them indefinitely. On the other hand, the cases do not deny that the executive branch acting alone has such power, and they affirm that the political branches acting together have such authority. Moreover, Hamdi definitively allows the government to detain citizens militarily, but preserves judicial review. As a result, the terrorism cases leave room for both civil libertarian and pro-government interpretations. ${ }^{322}$ The question is whether these cases, on the whole, represent progress, as contended by the distancing arguments, ${ }^{323}$ or regression. This Part compares the critical jurisprudential choices in the terrorism and internment cases to determine whether the law has truly progressed. In the end, the current cases do close some avenues toward governmental oppression forged by the internment cases, but they also leave many avenues open - and even expand them. As a consequence, the law has not progressed to the point where invocations of the internment are melodramatic or misplaced.

\section{A. A Caveat on the Meaning of Progress}

The concept of "progress" for the purposes of this Article is specifically civil libertarian. One certainly may contest that protection of civil liberties is more a benchmark of progress than safety and security, and many conservative theorists argue the executive's option to initiate actions like internment should be preserved. ${ }^{324}$ Others support post-9/11

322. Thus, a court predisposed toward a rights-expanding view will rely on Hamdi for the principle of governmental restraint. The district court in In re Guantanamo Detainee Cases, for example, cited Hamdi for the proposition that the detainees had a right to challenge their classifications as unlawful combatants before a neutral magistrate. See 355 F. Supp. 2d 443, 465 (D.C. Cir. 2005) ("Hamdi forms both the starting point and core of this Court's consideration of what process is due to the Guantanamo detainees in these cases."). On the other hand, the Fourth Circuit relied almost exclusively on Hamdi in concluding that the President had authority to detain Jose Padilla as an enemy combatant. Padilla v. Hanft, 423 F.3d 386 (4th Cir. 2005). Moreover, the government characterized Hamdi as standing for the proposition that detention powers may be exercised in the "war" against al Qaeda. See Brief for the Respondent in Opposition at 10, Padilla v. Hanft, 125 S. Ct. 2906 (2005) (No. 04-1342). ("In Hamdi, this Court confirmed that the military may seize and detain enemy combatants . . f for the duration of the relevant conflict with al Qaeda.").

323. See supra Part II.B (discussing the arguments).

324. See, e.g., MALKIN, supra note 91 (arguing that internment and racial profiling are necessary to protect the country). 
security measures short of internment, despite the negative effect on liberties. ${ }^{325}$ Engaging these arguments, however, is not the purpose of this Article. This Article is about the viability of invocations of the internment in the face of distancing arguments that internment is irrelevant because of the law and society's "progress." These distancing arguments take for granted a definition of progress that necessarily incorporates a higher regard for civil liberties than the conditions predicating the internment and the Hirabayashi and Korematsu decisions. $^{326}$

In terms of defending civil liberties, the progress of the law can be assessed through three models of legal reasoning. The least progressive model is judicial reasoning that finds executive wartime overreaching constitutional. Courts employ this reasoning when they approve military actions either by holding that the Constitution precludes judicial review, as did the Fourth Circuit in Hamdi, ${ }^{327}$ or by applying a constitutional test and finding the military action passes, as in Korematsu. ${ }^{328}$ Obviously the latter action is somewhat more progressive than the former, as the test might allow for increased judicial scrutiny as attendant circumstances change. For example, the strict scrutiny test, formulated in Korematsu, which the internment policies met, has been subsequently used to strike down racial classifications. ${ }^{329}$

In contrast, courts engage in the most progressive model of legal reasoning when they fully review abusive government policies and find them unconstitutional. Justice Murphy adopted this approach in Korematsu, opining that the Constitution simply does not allow processless detention of citizens on the basis of race, ${ }^{330}$ as did the Second Circuit in Padilla, holding that the Constitution does not permit the President to militarily detain citizens absent explicit congressional approval. ${ }^{331}$ This type of legal reasoning makes the detention power subject to

\footnotetext{
325. See, e.g., Muller, supra note 15.

326. Tushnet explains,

The social learning is this: Knowing that government officials in the past have in fact exaggerated threats to national security or have taken actions that were ineffective with respect to the threats that actually were present, we have become increasingly skeptical about contemporary claims regarding those threats, with the effect that the scope of proposed government responses to threats has decreased.

Tushnet, supra note 14, at 283-84.

327. Hamdi v. Rumsfeld, 316 F.3d 450, 466 (4th Cir. 2003), vacated, 542 U.S. 507 (2004).

328. Korematsu v. United States, 323 U.S. 214, 216-17 (1944).

329. E.g., Wygant v. Jackson Bd. of Educ., 476 U.S. 267 (1986); Palmore v. Sidoti, 466 U.S. 429 (1984).

330. Korematsu, 323 U.S. at 234-35 (Murphy, J., dissenting).

331. Padilla v. Rumsfeld, 352 F.3d 695, 699 (2d Cir. 2003), rev'd, 542 U.S. 426 (2004).
} 
constitutional restraint, thereby reducing the possibility of another internment. Had Justice Murphy's dissent been the majority opinion, the Supreme Court would have created a precedent that no matter the exigency, internment of citizens is simply unacceptable. If that were the case, my students could not defend racial profiling of terrorists on the precedential value of Korematsu. ${ }^{332}$

Somewhere uncomfortably in between these models is judicial abdication. Judicial abdication occurs when a court omits or mischaracterizes facts to reach a desired conclusion, or uses procedural technicalities to dispose of an important case without reaching the merits. For example, when the Court in Korematsu proclaimed, "we are dealing specifically with nothing but an exclusion order,"333 while ignoring the undeniable consequence of detention, it abandoned its duty to review the actual controversy at issue. ${ }^{334}$ Another example of abdication is the Padilla decision, in which the Court declined to rule on the merits of the case. The dissent accused the majority of using venue rules to avoid addressing issues of great importance. ${ }^{335}$

Judicial abdication is a middle-of-the-road approach because the court neither upholds nor condemns government abuses, but simply avoids the issue. On one hand, the action is progressive because it does not forge into law that which in hindsight is found to create oppression. ${ }^{336}$ On the other hand, abdication restricts rights because it takes away any possibility of a judicial remedy for individuals affected by the overreaching. ${ }^{337}$ Justice Jackson endorsed a policy of nearly total judicial abdication on wartime decisions in his Korematsu dissent. ${ }^{338}$ Similarly, scholars such as Mark Tushnet and Bruce Ackerman believe that judicial abdication is better than the alternative, which will

\footnotetext{
332. See supra note 13 and accompanying text.

333. Korematsu, 323 U.S. at 223.

334. See id. at 225-26 (Roberts, J., dissenting) (criticizing majority for ignoring the reality of detention).

335. Padilla, 542 U.S. at 464 (Stevens, J., dissenting).

336. See Korematsu, 323 U.S. at 246 (Jackson, J., dissenting) (criticizing the majority for validating racial discrimination).

337. See id. at 225-26 (Roberts, J., dissenting).

338. He famously stated,

$[\mathrm{O}]$ nce a judicial opinion rationalizes such an order to show that it conforms to the Constitution, or rather rationalizes the Constitution to show that the Constitution sanctions such an order, the Court for all time has validated the principle of racial discrimination in criminal procedure and of transplanting American citizens. The principle then lies about like a loaded weapon ready for the hand of any authority that can bring forward a plausible claim of an urgent need.

Id. at 246 (Jackson, J., dissenting).
} 
necessarily consist of politically minded judges fashioning decisions that give the executive undue latitude. ${ }^{339}$

Judicial abdication is an uncomfortable model, however, because it strikes both conservatives and liberals alike as not only unfair to litigants, but also distasteful as a matter of judicial integrity. ${ }^{340}$ Nonetheless, for the purposes of assessing whether the law has "progressed" from Hirabayashi and Korematsu to Hamdi, it seems judicial abdication is more protective of civil liberties and thus a higher measure of progress than constitutionally sanctioning executive overreaching. The next several subsections analyze whether certain choices made in the terrorism cases evidence a shift toward civil libertarian progress. They examine avenues toward governmental repression established in the internment cases and discuss whether these avenues have been closed, limited, or expanded by choices made by the modern Supreme Court.

\section{B. Government Power to Detain U.S. Citizens Militarily}

One of the crucial choices facing the Supreme Court in both the internment and terrorism detention cases was whether the government, during wartime, possesses the power to detain citizens militarily. This question implicates two separate but related issues. First, there is the issue of what predicate conditions allow the government to invoke the "war power" that permits military detention. Second, there is the question of whether, even when conditions establish wartime, the Constitution allows the military detention of U.S. citizens.

\section{Predicates of War Power}

The World War II cases provide only brief analyses of the proper triggers of war power, because at the time the United States clearly was engaged in a declared war. ${ }^{341}$ In Hirabayashi, the Court recognized

\footnotetext{
339. Ackerman, supra note 113, at 1030; Tushnet, supra note 14, at 307.

340. Indeed, there is something inherently distasteful about the Supreme Court mischaracterizing factual issues for the sole purpose of avoiding the real constitutional questions. Eugene Rostow criticizes Justice Jackson's abdication approach:

What Justice Jackson is saying seems to be this: Courts should refuse to decide hard cases, for in the hands of foolish judges they make bad law. The ark of the law must be protected against contamination.... Judges are thus to be relieved of the political responsibilities of citizenship and their office.

Eugene Rostow, The Japanese American Cases-A Disaster, 54 YALE L.J. 489, 511-12 (1945).

341. The United States declared war against Japan on December 8, 1941, and Executive Order 9066 was issued on February 19, 1942. Korematsu, 323 U.S. at 226 (Roberts, J., dissenting).
} 
Congress's declaration of war on Japan as part of the series of events creating authority for the military restrictions. It also characterized the military restrictions as taking place "in the crisis of war and of threatened invasion." 342 In other passages, the Court mentioned the "conditions with which the President and Congress were confronted," which included the attack of Pearl Harbor during diplomatic negotiations and Japanese military advances in the Pacific theater. ${ }^{343}$ The Court in Korematsu portrayed the exclusion order as "issued after we were at war with Japan." ${ }^{344}$ Similarly, the Court in Ex parte Quirin described Article II as

invest [ing] the President as Commander in Chief with the power to wage war which Congress has declared, and to carry into effect all laws passed by Congress for the conduct of war and for the government and regulation of the Armed Forces, and all laws defining and punishing offences against the law of nations.

Unlike the World War II cases, Hamdi did not address directly the factual predicates for invocation of war power. The Court never clearly stated whether the conflict in Afghanistan combined with the AUMF amounted to conditions of war sufficient to trigger Article II powers. The Court discussed at length Hamdi's detention as an exercise of war power, appearing to take for granted that exercise of war power was appropriate at the time President Bush detained Hamdi. ${ }^{346}$ The Court also repeatedly referred to "active hostilities",347 and "armed conflict,"348 without definitively concluding that such conditions were themselves enough to trigger the exercise of extra-constitutional war power. The Court was also vague as to the role of the AUMF in initiating war power. ${ }^{349}$ The Court did not address whether the AUMF was the functional equivalent of a declaration of war that engendered the full panoply of war powers. Rather, the Court referenced the AUMF primarily to establish that Congress specifically approved Hamdi's detention. ${ }^{350}$

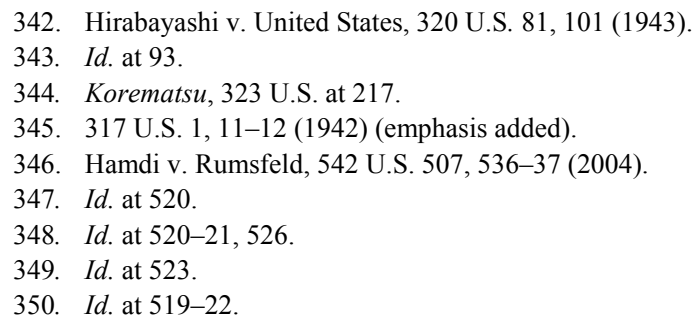


The Fourth Circuit, in Hamdi, had more overtly addressed the issue of the predicates of war power. ${ }^{351}$ The court asserted that the military detention scheme was dependent, not on a formal declaration of war, but rather on the scheme "aris[ing] in the context of foreign relations and national security." 352 The Fourth Circuit sought to give the political branches extremely broad, review-free authority, not only to create policy regarding foreign combat operations, but also more generally to wage the War on Terror. The court opined that "the "political branches are best positioned to comprehend this global war in its full context,' and neither the absence of set-piece battles nor the intervals of calm between terrorist assaults suffice to nullify the warmaking authority entrusted to the executive and legislative branches." 353

The Supreme Court in Hamdi did not embrace explicitly the broad view that the political branches could exercise war powers in the name of the War on Terror, absent active military conflict. ${ }^{354}$ Nonetheless, even interpreting the case in the most restrictive manner as requiring both the AUMF (or a legislative equivalent) and factual war-like conditions to trigger war powers, those requirements still fall well short of a formal declaration of war, as contemplated in Hirabayashi, Korematsu, and Quirin. A formal declaration of war requires specificity on the part of Congress, such that congressional intent to engage in combat with a particular country is easily established. ${ }^{355}$ The AUMF, by contrast, generally authorizes "necessary" action against those parties responsible for the 9/11 attacks. ${ }^{356}$ Construing the AUMF as the functional equivalent of a declaration of war allows the President to exercise war power pursuant to a vague approval of military force against parties yet unknown. Under this approach, any military action in the name of terrorism prevention triggers the same powers as a declared war. ${ }^{357}$

351. Hamdi v. Rumsfeld, 296 F.3d 278, 281-82 (4th Cir. 2002).

352. Id. at 281 .

353. Hamdi v. Rumsfeld, 316 F.3d 450, 464 (4th Cir. 2003), vacated, 542 U.S. 507 (2004) (quoting Hamdi, 296 F.3d at 283). Elsewhere in the Hamdi opinions, the Fourth Circuit articulates a slightly more restrictive view of the war power by characterizing it as triggered "in times of active hostilities," Hamdi, 296 F.3d at 281, and dependent on being exercised as a "military judgment[] in the field," Hamdi, 316 F.3d at 465.

354. See supra notes 346-49 and accompanying text

355. See Neal K. Katyal \& Laurence H. Tribe, Waging War, Deciding Guilt: Trying the Military Tribunals, 111 YALE L.J. 1259, 1272 (2002) (stating that "a declaration of war usefully confines the circumstances in which military tribunals may be used and limits their jurisdiction to a finite period of time").

356. See supra note 259 and accompanying text.

357. Katyal and Tribe reject the contention that the AUMF acts as a formal declaration of war. Katyal \& Tribe, supra note 355, at 1284-85 ("Nothing even close to that World War II 
Consequently, equating the AUMF with a formal declaration of war grants more power to the executive to create unilaterally the predicates for expansive war power.

Moreover, a declaration of war contemplates a finite length of conflict, such that when a peace treaty is executed with the particular enemy country, the war power authority generally ends. ${ }^{358}$ In contrast, the AUMF is incredibly broad, allowing for the existence of war powers in perpetuity so long as the executive engages in military actions directed against Al Qaeda or related terrorist groups. As a result, the executive can assert, as the Fourth Circuit did, that any military detention in the name of terrorism prevention is an exercise of a war power. ${ }^{359}$ Granted, the Supreme Court in Hamdi was careful to note the existence of warlike conditions in Afghanistan, including active fighting and troop deployment. $^{360}$ The problem is that in the absence of a formal declaration of war, the issue of the conditions triggering war power becomes more open to interpretation and expansion. Hamdi leaves open the possibility that the AUMF allows for military detention power, even when there is little indication of war-like conditions, for example, during continued military occupation, engagement in isolated skirmishes, ongoing police actions, or deployment as peacekeepers. ${ }^{361}$

In addition, the Hamdi opinion does not make clear that legislation is necessary to trigger war powers. While Hamdi relies on the existence of the AUMF to find congressional approval for the specific detention scheme, it does not explicate that congressional action is required to

authorization, or a wartime emergency in which Congress's consent cannot be obtained, is present today.").

358. See id. at 1272 (discussing the role of a declaration of war); see also Ludecke v. Watkins, 335 U.S. 160, 166-70 (1948) (stating that a peace treaty is a major factor in determining that war powers have ceased); In re Yamashita, 327 U.S. 1, 13 (1946) ("The extent to which the power to prosecute violations of the law of war shall be exercised ... may itself be governed by the terms of an armistice or the treaty of peace."); John Alan Cohan, Legal War: When Does It Exist, and When Does It End?, 27 HASTINGS INT'L \& COMP. L. REV. 221 (2004) (examining U.S. law regarding the formal declaration of war).

359. Hamdi v. Rumsfeld, 296 F.3d 278, 281-82 (4th Cir. 2002).

360. Hamdi v. Rumsfeld, 542 U.S. 507, 516-22 (2004).

361. See id. This is a departure from the norm that military detention power only exists during a time of war. Major Michael Newton explains,

During operations other than war, commanders could view military commissions as an aspect of their inherent authority to prosecute any offender for any violation of international law that impedes the military mission. However, ... history and judicial precedent show that military commissions have jurisdiction only in the context of what was historically termed war....

Major Michael A. Newton, Continuum Crimes: Military Jurisdiction Over Foreign Nationals Who Commit International Crimes, 153 MIL. L. REV. 1, 15 (1996). 
trigger war power. ${ }^{362}$ Rather, the Court pointed to the continued troop engagement with "Taliban fighters" as a basis for the ongoing detention of Hamdi. ${ }^{363}$ This allows for the interpretation that war powers are triggered even when the executive engages unilaterally in armed conflict abroad. In the end, the Hamdi case leaves open the possibility that war powers can be invoked absent a declaration of war, or even any congressional approval of military action, and/or in the absence of paradigmatic war-like conditions. This is a far more broad construction of "wartime" than in Hirabayashi, Korematsu, and Quirin.

The potential for repression inherent in broadening the triggers of war power is illustrated by the government and district court's position in Padilla. The government had set forth an interpretation of wartime, in which the President may properly exercise war power pursuant to "an undeclared war... between Al Qaeda and the United States."364 The government urged broad exercise of Article II power in the absence of both traditional armed conflict and congressional approval. The district court agreed, finding that war power could be properly derived from the undefined War on Terror. ${ }^{365}$ Relying on The Prize Cases, ${ }^{366}$ the court reasoned that "a formal declaration of war is not necessary for the executive to exercise its constitutional authority to prosecute an armed conflict." "367 The Prize Cases involved an executive-ordered blockade during an insurrection leading up to the Civil War. ${ }^{368}$ The Supreme Court held that certain war powers could be invoked in the absence of a formal declaration of war when the nation was threatened by civil insurgency or foreign invasion. ${ }^{369}$ The district court in Padilla concluded that The Prize Cases broadly stood "for the proposition that the President has independent authority to repel aggressive acts by third parties even without specific congressional authorization.", 370 The district court thus assumed, without reasoning, that Padilla's detention was in the context of "repel[ling] an aggressive act." 371 The court

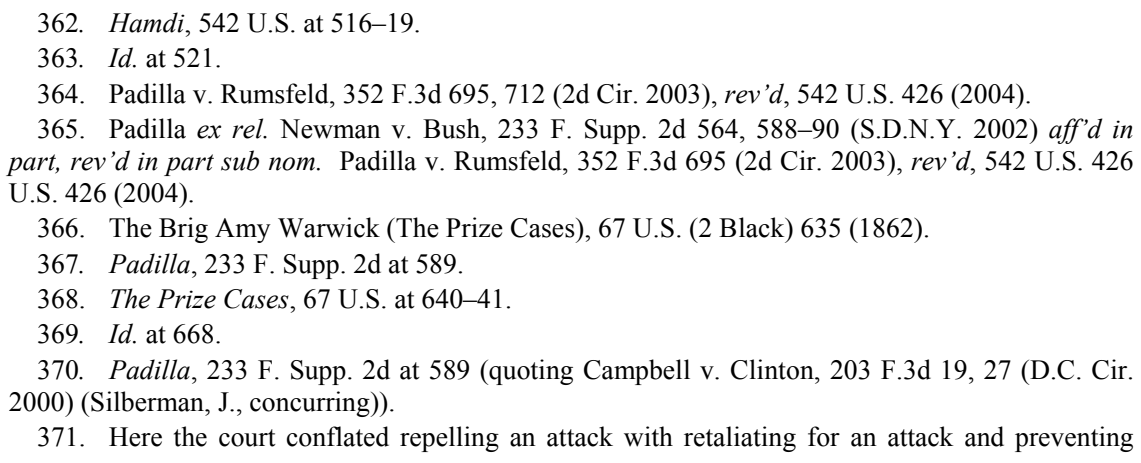

371. Here the court conflated repelling an attack with retaliating for an attack and preventing 
likened the general threat of acts of terror to the specific threat of invasion discussed in The Prize Cases. By elevating the current terrorism risk to the level of exigency facing the nation during The Prize Cases, the court endorsed the notion that the government may freely ignore the Constitution in any prosecution of alleged terrorists.

The Second Circuit in Padilla declined to address the issue of whether the predicate conditions for invoking war power existed, ${ }^{372}$ instead ruling that even the proper invocation of war power would not permit the detention of a U.S. citizen without an express authorization from Congress, which, according to the court, was not present in the AUMF. ${ }^{373}$ The Supreme Court did not rule on any of the substantive issues in Padilla and therefore neither endorsed nor rejected the contention that the War on Terror gave the government the ability to exercise military detention power in the name of antiterrorism. ${ }^{374}$ There is, however, some language in Hamdi indicating that a semantic War on Terror may not be enough of a predicate for the invocation of war powers. Specifically, the Court recognized that war power might not be appropriate "if the practical circumstances of a given conflict are entirely unlike those of the conflicts that informed the development of the law of war." 375 The Court nonetheless found war power appropriate because "[a]ctive combat operations against Taliban fighters apparently are ongoing in Afghanistan." 376 One can read this to require at least "active combat operations" or some equivalent as a predicate for the use of war

future attacks. The court noted that in the last several "wars," the executive took unilateral military action. Id. at 589-90. There are, however, significant differences between the Vietnam War and the War on Terror. First of all, the Vietnam War was war-like in the sense that it involved military action against an organized, identifiable foreign army, in a distinct geographical region, with temporal limitations. More importantly, the Vietnam-era cases cited in Padilla only dealt with whether courts could get involved in the conflict between Congress and the executive in the declaration of war in Vietnam. See, e.g., Mitchell v. Laird, 488 F.2d 611, 613-14 (D.C. Cir. 1973). The courts were loath to get involved in a dispute between the political branches and found ways to avoid it. This is a wholly different issue than the issue of detention power during such a conflict. The executive's possible ability to constitutionally prosecute a war for a period of time without a formal declaration from Congress does not necessarily compel the conclusion that during that period of time the executive may invoke the full panoply of war powers, including military detention power and the authority to expel enemy aliens. The Youngstown case made clear that during the undeclared Korean War, the president did not have the authority to seize steel companies. Youngstown Sheet \& Tube Co. v. Sawyer, 343 U.S. 579 (1952).

372. See Padilla v. Rumsfeld, 352 F.3d 695 (2d Cir. 2003), rev'd, 542 U.S. 426 (2004) (“[W]e do not address the government's underlying assumption that an undeclared war exists between al Qaeda and the United States.").

373. Id. at 724 .

374. See supra notes 262-72 and accompanying text (discussing the resolution of Padilla on procedural grounds).

375. Hamdi v. Rumsfeld, 542 U.S. 507, 521 (2004).

376. Id. 
powers. However, this still leaves room for an interpretation that the existence of "active combat operations" against terrorist organizations somewhere in the world authorizes the President to detain militarily all suspected members of those and other terrorist organizations. ${ }^{377}$

Consequently, even putting the most civil libertarian spin on the Supreme Court's treatment of war power in Hamdi, the case expands the triggering events from a narrow, formal declaration of war against a specific country to, at best, military operations combined with a generalized authorization of force against terrorists and, at worst, the undeclared War on Terror. The Court in Padilla declined to issue a holding reigning in the authorizing power of the AUMF or narrowing the concept of war powers. As a result, these cases taken together inflate the government's ability to exercise extensive war power and engage in military detentions. Thus, on this particular issue, Hamdi and Padilla cannot be said to represent a more progressive stance than Hirabayashi and Korematsu.

\section{Applicability of Military Detention to U.S. Citizens}

Once a court decides that triggering wartime conditions exist, it must determine whether the governmental program at issue is a legitimate exercise of war power. The particular program at issue in both Hamdi and Padilla was the detention of U.S. citizens as enemy combatants. Hamdi represents the narrower program of militarily detaining U.S. citizens who purportedly fight with the enemy in a foreign theater, 378 whereas Padilla represents the broader program of militarily detaining U.S. citizens with purported ties to terrorism who were captured domestically. ${ }^{379}$ The Supreme Court's approach to these detention programs should be understood on a backdrop of the Court's jurisprudence on citizen military detentions, starting with the Civil War case Ex Parte Milligan. ${ }^{380}$

377. The district court in Padilla adopted this precise interpretation when it found that combat operations in Iraq and Afghanistan allowed the president to detain Jose Padilla, who had alleged ties to terrorism, but no particular ties to the conflicts in Iraq or Afghanistan. Padilla ex rel. Newman v. Bush, 233 F. Supp. 2d 564, 590 (S.D.N.Y. 2002), aff'd in part, rev'd in part sub nom. Padilla v. Rumsfeld, 352 F.3d 695 (2d Cir. 2003), rev'd, 542 U.S. 426 (2004).

378. See Hamdi v. Rumsfeld, 316 F.3d 450, 465 (4th Cir. 2003), vacated, 542 U.S. 507 (2004) ("We shall, in fact, go no further in this case than the specific context before us-that of the undisputed detention of a citizen during a combat operation undertaken in a foreign country and a determination by the executive that the citizen was allied with enemy forces.").

379. See generally Padilla v. Hanft, 389 F. Supp. 2d 678 (D.S.C. 2005), rev'd, 423 F.3d 386 (4th Cir. 2005).

380. 71 U.S. 2 (1866). 
In 1864, Lamdin Milligan, an American citizen and Indiana resident, went to trial before a military tribunal on charges of conspiracy against the United States, affording aid and comfort to rebels, inciting insurrection, disloyal practices, and violation of the laws of war. ${ }^{381}$ Milligan challenged his military detention and trial, and the case eventually went to the Supreme Court. The Court sought primarily to answer the question of whether "the military commission [had] jurisdiction, legally, to try and sentence said Milligan." ${ }^{382}$ The Court began by venerating the rights attendant to a criminal trial. The Court characterized the criminal trial as "the birthright of every American citizen" 383 and stated, "By the protection of the law human rights are secured; withdraw that protection, and they are at the mercy of wicked rulers." 384

The Court then considered the government's contention that military jurisdiction over alleged war criminals was "complete under the laws and usages of war." 385 In denying the government's argument, the Court denounced the idea that the existence of conflict necessitated abandonment of constitutional protections:

All . . persons, citizens of states where the courts are open, if charged with crime, are guaranteed the inestimable privilege of trial by jury. This privilege is a vital principle, underlying the whole administration of criminal justice; it is not held by sufferance, and cannot be frittered away on any plea of state or political necessity. When peace prevails, and the authority of the government is undisputed, there is no difficulty of preserving the safeguards of liberty . . . but if society is disturbed by civil commotion - if the passions of men are aroused and the restraints of law weakened, if not disregarded - these safeguards need, and should receive, the watchful care of those entrusted with the guardianship of the Constitution and laws. In no other way can we transmit to posteritv unimpaired the blessings of liberty, consecrated by the sacrifices of the Revolution. ${ }^{386}$

To illustrate the sensitivity of the "Revolutionary fathers" 387 to the concept of military justice usurping the Constitution, the Court cited the 1815 case of Smith v. Shaw, ${ }^{388}$ in which it had held that although military

381. Id. at 6.

382. Id. at 8 .

383. Id. at 119 .

384. Id.

385. Id. at 121 .

386. Id. at $123-24$.

387. Id. at 128 .

388. 12 Johns. 257 (N.Y. 1815), cited in Milligan, 71 U.S. at 129. 
charges might be appropriate for suspected foreign spies, if an individual "was an American citizen, he could not be charged with such an offence." 389 The Court observed that an American citizen "might be amenable to the civil authority for treason; but could not be punished, under martial law, as a spy." 390

The Supreme Court made its next statement on wartime power to detain U.S. citizens in Ex parte Quirin ${ }^{391}$ a case Justice Scalia has characterized as "not this Court's finest hour."392 Professor Jonathan Turley writes of the "little known background to Quirin" and concludes that the case's history "should give pause to anyone relying on its precedential value or the specific tribunal rules written in World War II for these trials." $" 393$ Quirin involved eight German saboteurs sent by Hitler to the United States during World War II. Two of the spies, Haupt and Burger, were U.S. citizens. ${ }^{394}$ After the spies arrived on American shores, the leader of the group, Dasch, revealed that he intended to betray the mission. ${ }^{395}$ Dasch called the FBI, reported the mission, and was promptly ignored. ${ }^{396}$ Only after Dasch flew to Washington, showed the FBI funds, and gave a 254-page statement, did the FBI, with Dasch's help, round up the remaining spies. ${ }^{397}$ Subsequent to the surrender of the spies, J. Edgar Hoover convened a press conference and falsely announced that the FBI had alone investigated and initiated the arrests. ${ }^{398}$ The FBI falsified Dasch's arrest date to make it appear that the group of spies had been arrested en masse. ${ }^{399}$ This announcement led to public accolades for the FBI, and Hoover received a congressional medal for his efforts. $^{400}$

From the outset, President Roosevelt and Attorney General Biddle made it clear that they did not want the men tried in open proceedings where legal presumptions and standards applied. ${ }^{401}$ The Attorney General suggested a makeshift military procedure, which would allow

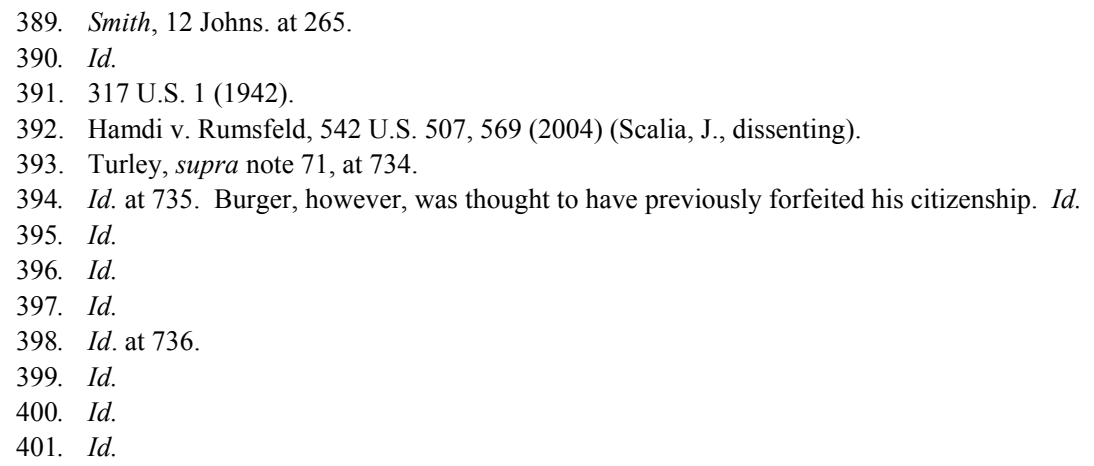


for a trial without constitutional protections, while not requiring congressional suspension of the writ. ${ }^{402}$ From the beginning, President Roosevelt engaged the Supreme Court in overseeing the military proceedings and advising the parties on how to proceed. ${ }^{403}$ The President wrote a memo to the Attorney General, which was later communicated to the Supreme Court, stating, "I won't give them up ... I won't hand them over to any United States marshal armed with a writ of habeas corpus. Understand?" 404 After six of the eight men were executed, the Supreme Court labored for a decision approving the process that had been so important to the President and in which they had been so intimately involved. Professor Turley comments,

After the executions, the Court attempted to justify its decision, a process that Justice Stone called "a mortification of the flesh." Stone struggled with the justification, particularly in light of Ex Parte Milligan. Historian Belknap has denounced the decision as an effort "not to elucidate the law ... but rather to justify as best he could a dubious decision." 405

As to the substance of the Quirin opinion itself, the Court gave broad authority to the political branches to bypass the Constitution in trying enemy combatants during time of war. The Court began with the observation that a declared war triggers broad war powers. ${ }^{406}$ The Court then opined that under the laws of war, enemy belligerents could be captured and subjected to military detention and procedures. ${ }^{407}$ It further stated that the law of war distinguished between lawful combatants, who are treated as prisoners of war, and those who violate the laws of war, who are treated as unlawful combatants and subject to trial by military

\footnotetext{
402. Turley explains,

Biddle asked Roosevelt to issue an order that would effectively close civil courts to the men, who were transferred from civilian to military control.... This executive control was so great that the military officers given the duty to defend the Germans were not clear that they could file a constitutional challenge that would effectively disobey their Commander in Chief.

403. See id. at 737 (stating that "from the earliest stage, the Administration enlisted the advice of Supreme Court justices who would ultimately decide the case").

404. See id. at 738 (quoting David J. Danelski, The Saboteurs' Case, 1 J. OF SuP. CT. Hist. 61, 68 (1996)).

405. Id. at 739-40 (quoting respectively AlPHEUS T. MASON, HARLAN FISKE StONE: PILlaR OF THE LAW 659 (1956) \& Michael R. Belknap, The Supreme Court Goes to War: The Meaning and Implications of the Nazi Saboteur Case, 89 MIL. L. REV. 59, 87 (1980)).

406. Ex parte Quirin, 317 U.S. 1, 26 (1942).

407. Id. at $30-31$
} 
tribunal. $^{408}$ In concluding that the German spies were indeed unlawful combatants, the Court asserted that "those who during time of war pass surreptitiously from enemy territory into our own, discarding their uniforms upon entry, for the commission of hostile acts involving destruction of life or property, have the status of unlawful combatants punishable as such by military commission." $\$ 409$

The Court gave incredibly short shrift to the question of whether a U.S. citizen could be subjected to military proceedings, despite the existence of a plethora of criminal causes of action addressing the same behavior. ${ }^{410}$ In a single, conclusory paragraph the Court declared, "Citizenship in the United States of an enemy belligerent does not relieve him from the consequences of a belligerency which is unlawful because in violation of the law of war." ${ }^{411}$ Later in the opinion, the Court attempted to justify its holding in the face of Milligan. In a similar conclusory fashion, the Court distinguished Quirin by describing the Milligan holding as dependent on the characterization of Milligan as "a non-belligerent, not subject to the law of war."

Justice Scalia, in his Hamdi dissent, criticized Quirin's treatment of Milligan as "seek[ing] to revise Milligan rather than describe it." Scalia argued that Milligan contains "categorical language" that the law of war is inapplicable to citizens while civilian courts are functioning. ${ }^{414}$ Scalia asserted that alternatively the only way Quirin and Milligan could be reconciled was if the law of war applied only to "conceded" citizen belligerents, like Haupt, and not to those who contest their belligerent status, like Milligan and Hamdi. ${ }^{415}$

Although issued by the same Court that issued Quirin, the internment cases basically ignore the question of whether the government, in wartime, can militarily detain its own citizens. It seems beyond belief that when addressing the largest systematic military detention of U.S. citizens in history, ${ }^{416}$ the Court would simply side step the question of detention power. The Court, however, patently refused to characterize

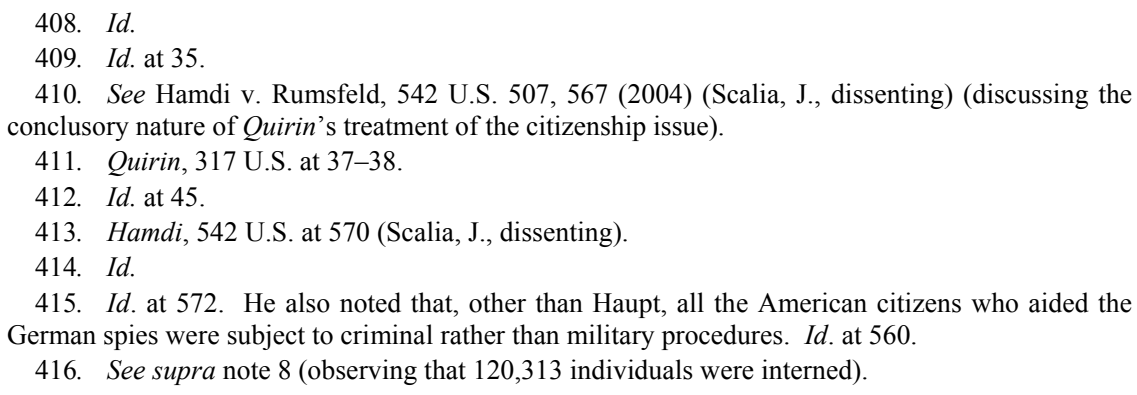


the combination of curfew and exclusion orders as amounting to a scheme in which the only option left to the Japanese was incarceration. ${ }^{417}$ Rather, it put a stamp of approval only on the government's ability to restrict certain rights to prevent espionage. ${ }^{418}$ Much to the dismay of Justice Roberts, the Supreme Court approved of a fictional situation, in which citizens were not detained, rather than analyzing the reality of internment. $^{419}$

In Endo, the Supreme Court could not ignore the issue of detention in a relocation camp. ${ }^{420}$ The Court, however, characterized the detention program as civilian to conclude that no issues of military law were present, making Quirin and Milligan inapplicable. ${ }^{421}$ Moreover, the Court disposed of the case, not by deciding whether the government could detain citizens as an exercise of war power, but rather by determining that Congress had not delegated to the civilian War Relocation Authority power to effectuate the particular policy that detained Endo. ${ }^{422}$ The Court thus characterized Endo's continued detention as beyond the scope of War Relocation Authority powers and granted Endo relief, without addressing any constitutional issues. ${ }^{423}$

Consequently, as to the particular issue of military detention of U.S. citizens, the Court in the internment cases engaged in total judicial abdication. Many view this approach as the worst possible response to governmental abuse and lodge critiques like that of Justice Roberts. ${ }^{424}$ Again, however, this Article places the abdication response in the middle ground because of the reasoning outlined by Justice Douglas and Professor Tushnet. ${ }^{425}$ Although abdication renders the law unable to address problems in real time, it still falls short of putting the constitutional stamp of approval on rights infringements to accommodate the emergency policies of the political branches. One benefit of the judicial abdication in Korematsu is that it rendered the case ill fit to serve

\footnotetext{
417. Korematsu v. United States, 323 U.S. 214, 222-23 (1944).

418. See generally Korematsu, 323 U.S. 214 (approving of an exclusion order); Hirabayashi v. United States, 320 U.S. 81 (1943) (approving of a curfew order).

419. Korematsu, 323 U.S. at 225-26 (Roberts, J., dissenting).

420. Ex parte Endo, 323 U.S. 283 (1944). Endo had actually challenged her continued detention rather than the exclusion order that predicated the detention. Id. at 294.

421. Id. at 297-98.

422. Id.

423. Id. at 304 .

424. Korematsu, 323 U.S. at 225-26 (Roberts, J., dissenting).

425. See supra notes 333-38 and accompanying text (discussing why judicial abdication is a middle-ground approach).
} 
as formal precedent for future military detention of citizens such as Hamdi and Padilla.

Unlike the internment cases, Hamdi answered the question of whether war power includes the power to detain U.S. citizens militarily in the affirmative, announcing concretely that the government can detain citizens as enemy combatants. ${ }^{426}$ The Court unequivocally stated, "There is no bar to this Nation's holding one of its own citizens as an enemy combatant." 427 The Court reasoned that a U.S. citizen, just like a foreign soldier, could be detained during hostilities because "such a citizen, if released, would pose the same threat of returning to the front during the ongoing conflict." 428 This reasoning, however, completely ignores the contention, accepted in Milligan, that alternate detention procedures exist for citizens who consort with the enemy. The situation of a U.S. citizen combatant is extremely different from that of a foreign combatant who has not otherwise violated U.S. law and cannot be held except militarily. ${ }^{429}$

In addition, Hamdi not only approved of detention of citizens who fought for the enemy overseas, but also, by relying on Quirin, endorsed a domestic espionage rationale for citizen detention, ${ }^{430}$ precisely the rationale that Korematsu used to justify the restrictions on the Japanese. ${ }^{431}$ O'Connor quoted Quirin for the proposition that "citizens who associate themselves with the military arm of the enemy government ... are enemy belligerents within the meaning ... of the law of war." ${ }^{432}$ There is no express limitation that the combatants either be active frontline fighters or captured abroad. ${ }^{433}$ Consequently, the Supreme Court implicitly sanctioned the view that war powers include the ability to detain citizens for aiding the enemy domestically or abroad.

\footnotetext{
426. Hamdi v. Rumsfeld, 542 U.S. 507, 519 (2004).

427. Id.

428. Id.

429. See id. at 553-78 (Scalia, J., dissenting). Further support for the criticism of the plurality's assumption that Hamdi's case mirrored that of a foreign prisoner of war is that the government never treated Hamdi like a garden-variety prisoner of war. See id. at 539-53 (Souter, J., dissenting). Thus, even the government assumed that Hamdi would eventually be subjected to criminal proceedings.

430. This is because Quirin premised the enemy combatant classification not on the fact that the detainees had fought against the United States in a foreign theater, but on the fact that the detainees had committed domestic espionage. See supra notes 393-412 and accompanying text for a discussion of the Quirin case.

431. See supra notes 174-78 and accompanying text (noting that the government based the restrictions on the presumed disloyalty of the Japanese).

432. Hamdi, 542 U.S. at 519.

433. Relying on Hamdi, the Fourth Circuit in Padilla, 423 F.3d 386, held that a person who never took up arms against the United States in a foreign battlefield and was captured domestically was nonetheless an enemy combatant.
} 
This is a far more direct empowerment of the government, and hence a greater restriction of civil liberties, than the position represented in the internment cases.

The most progressive modern approach to the question of citizen detention was forged by conservative Justice Scalia in his Hamdi dissent, which states, relying on Milligan, that absent invocation of the Suspension Clause, the government simply does not have the power to detain U.S. citizens militarily whether or not a war is ongoing. ${ }^{434}$ Justice Scalia framed the main question as "whether there is a different, special procedure for imprisonment of a citizen accused of wrongdoing by aiding the enemy in wartime." ${ }^{435}$ Scalia asserted that the process described by the plurality for detaining the enemy until hostilities ceased was a process that applied to foreigners but not citizens. Rather, citizenenemies are subject to the traditional criminal procedures outlined in the Constitution. Scalia extolled the Constitution's capability to address and meet crises of war and criticized the plurality for eroding rights in a nondemocratic fashion. He stated, "If civil rights are to be curtailed during wartime, it must be done openly and democratically, as the Constitution requires, rather than by silent erosion through an opinion of this Court." 436 While Justice Scalia's dissent represents a more progressive approach to military detention power than the judicial silence of the internment cases, the plurality opinion in Hamdi does not. Rather than denying the government authority to militarily detain citizens or remaining silent on the issue, the Court expressly upholds such authority.

\section{Executive Unilateralism}

The second critical choice presented to the Supreme Court in both the internment cases and Hamdi concerned the issue of unilateral or plenary executive detention power during wartime. Specifically, each Court had to determine whether the President, as Commander in Chief, alone possessed the detention power. ${ }^{437}$ Again, in context, the most progressive approach to this issue would require both branches of government to act in tandem when carrying out wartime detentions. ${ }^{438}$

\footnotetext{
434. Hamdi, 542 U.S. at 553-78 (Scalia, J., dissenting).

435. Id. at 558 .

436. Id. at 578

437. See id. at 516 (majority opinion).

438. This approach is exemplified by the Second Circuit's decision in Padilla, which required that the detention power always be exercised by both branches of government. Padilla v. Rumsfeld, 352 F.3d 695, 712-13 (2d Cir. 2003), rev'd, 542 U.S. 426 (2004).
} 
The most rights-restricting approach would grant the President unilateral authority. ${ }^{439}$ The internment cases and Hamdi are situated in between, but on different areas of the spectrum. The cases do not reach the question of executive unilateralism because they conclude that the President and Congress had, in fact, acted together. ${ }^{440}$ The critical difference between the internment cases and Hamdi, however, is how the Supreme Court came to the conclusion that Congress had authorized the policies at issue. The Hamdi Court strained to find legislative authorization in a way that gave much more leeway to the President to act unilaterally in carrying out military detentions.

Turning to the internment cases first, in Hirabayashi, the petitioner argued that Congress had unconstitutionally delegated its power by granting the executive broad authority to carry out war measures without specifically mandating policies, such as the curfew at issue. ${ }^{441}$ The Court meticulously analyzed the language of the delegating legislation, its history, and the timing of executive policy making and congressional approval $^{442}$ to hold "that the Act of March 21, 1942, contemplated and authorized the curfew order which we have before us." 443 The Court observed that the express purpose of the Act, according to committee reports, was to implement Executive Order No. 9066 $6^{444}$ and that committee reports mentioned curfews as the precise type of policy contemplated by the Executive Order. ${ }^{45}$ The Court further noted that during the time the Act was under consideration by Congress, the Chairman of the House Military Affairs Committee stated on the floor of the Senate that the proposed legislation was a means of enforcing Executive Order No. 9066 and its policies, including curfews. ${ }^{446}$ These facts, taken together, prompted the Court to conclude that "the legislative history demonstrates that Congress was advised that curfew orders were

439. For example, the district court in Padilla held that the President, acting alone, had constitutional power to detain enemy combatants. Padilla ex rel. Newman v. Bush, 233 F. Supp. 2 d 564, 589 (S.D.N.Y. 2002), aff'd in part, rev'd in part sub nom. Padilla v. Rumsfeld, 352 F. 3d 695 (2d Cir. 2003), rev'd, 542 U.S. 426 (2004).

440. See supra note 364 and accompanying text (explaining that when the political branches act together to declare war, the executive's use of war powers is constitutional).

441. Hirabayashi v. United States, 320 U.S. 81, 89 (1943).

442. Id. at 89-92.

443. Id. at 89

444. Id. at 89-90. See also supra note 159 and accompanying text (describing directive of Executive Order 9066).

445. Id. at 89-92.

446. During the time the Act was under consideration by Congress, General DeWitt sent letters to the Chairman of the House Military Affairs Committee requesting that the Act grant military commanders the power to impose curfews. Id. at 90-91. 
among those intended, and was advised also that regulation of citizen and alien Japanese alike was contemplated." ${ }^{447}$ The Court characterized Congress's action as unequivocal, stating that "so far as it lawfully could, Congress authorized and implemented such curfew orders as the commanding officer should promulgate pursuant to the Executive Order of the President," ${ }^{448}$ and held that "[t]he conclusion is inescapable that Congress, by the Act of March 21, 1942, ratified and confirmed Executive Order No. 9066." 449 The Court thus declined to address the issue of executive unilateralism, stating, "We have no occasion to consider whether the President, acting alone, could lawfully have made the curfew order in question, or have authorized others to make it." 450 Similarly, in Korematsu, the Court easily dismissed the question of executive unilateralism, as Korematsu was arrested for violation of a specific legislative provision making it a crime to "enter, remain in, leave, or commit any act in a military area or military zone." $" 451$

The Quirin case represents a slightly more executive-empowering approach than the internment cases, but still falls well short of Hamdi. As in the internment cases, the Court did not answer the question of whether the executive had unilateral authority to detain and try enemy combatants because it concluded that the military trials at issue were authorized by Congress. The Court stated that it was "unnecessary for present purposes to determine to what extent the President as Commander in Chief has constitutional power to create military commissions without the support of Congressional legislation." ${ }^{, 452}$ In finding congressional authorization, the Court relied not only on the declaration of war, but also on specific language in the congressional Articles of War. The Court held,

By the Articles of War, Congress has provided rules for the government of the Army.... [T] he Articles also recognize the "military commission" appointed by military command as an appropriate tribunal for the trial and punishment of offenses against the law of war not ordinarily tried by court martial. ${ }^{453}$

\footnotetext{
447. Id. at 91.

448. Id.

449. Id.

450. Id. at 92 .

451. Korematsu v. United States, 323 U.S. 214, 216 (1944).

452. Ex parte Quirin, 317 U.S. 1, 29 (1942).

453. Id. at 26-27 (internal citation omitted).
} 
While Article 15 made it rather clear that military commissions had jurisdiction to try offenses against the laws of war (as defined elsewhere in the Articles of War), it was less clear whether the Articles provided jurisdiction over foreign nationals and U.S. civilians rather than just military personnel. ${ }^{454}$ Because the justices were unwilling to find retrospectively that the government had acted unconstitutionally in militarily trying the spies, the difficult choice confronting them was whether to find that the President had unilateral authority to try the spies or whether to read Article 15 as applying to foreign nationals and civilians as well as to military personnel. ${ }^{455}$ Professor Edward White explains that "none of Stone's fellow justices was prepared to deny that U.S. military commissions could properly try agents of enemy nations for going behind American lines in civilian dress to commit hostile acts." 456 Accordingly, the Court interpreted the Articles of War as permitting the military tribunals.

Another potential problem for the Court was that it was not clear whether the process Roosevelt had set up to govern the tribunals fully conformed with the Articles of War. For example, the process did not include approval by a Judge Advocate General review board, as required by Articles 46 and 50-1/2. ${ }^{457}$ Nevertheless, the Court summarily ruled that the military tribunals conformed to the Articles of War and was "unanimous in its conclusion that the Articles in question could not at any stage of the proceedings afford any basis for issuing the writ [of habeas corpus]." 458 Despite the existence of these inconsistencies, the Articles of War contained specific language from which the Supreme Court could conclude that Congress had specifically authorized the executive to try unlawful combatants by military proceedings. ${ }^{459}$

454. Professor Edward White observes that "it was not clear that Congress had contemplated the use of such commissions to try foreign nationals, or Americans not serving in the military, for offenses based on the international law of war as well as violations of the Articles of War themselves." G. Edward White, Felix Frankfurter's "Soliloquy" in Ex parte Quirin: Nazi Sabotage \& Constitutional Conundrums, 5 GREEN BAG 2D 423, 430 (2002).

455. Id. at 431 .

456. Id. at 430

457. Id. at 427 .

458. Id. at 435 .

459. Provisions of the Articles of War still exist today in the Uniform Code of Military Justice (UCMJ). Specifically, the statute states, "The provisions of this chapter conferring jurisdiction upon courts-martial do not deprive military commissions, provost courts, or other military tribunals of concurrent jurisdiction with respect to offenders or offenses that by statute or by the law of war may be tried by military commissions, provost courts, or other military tribunals." 10 U.S.C. $§ 821$ (2005). Given this provision, one might wonder whether the Supreme Court could have found authorization for Hamdi's detention in the UCMJ, as did the Quirin Court. None of the courts reviewing Hamdi or Padilla's detention have found the UCMJ to be an expression of congressional 
Moving forward to the terrorism cases, it is important to note that between World War II and now, in response to the horrors of internment, Congress passed the Nondetention Act, signifying its intention to prohibit any detention of a U.S. citizen without its express assent. ${ }^{460}$ In Hamdi, the Supreme Court declined to comment on whether the President had authority acting alone to imprison a citizen because it found congressional approval of the detention. ${ }^{461}$ The Court relied exclusively on the AUMF as the necessary expression of congressional agreement. ${ }^{462}$ It essentially had no other choice but to place sole reliance on the AUMF, as Congress was otherwise silent on the President's detention decisions.

Days after 9/11, Congress enacted the AUMF, which authorized the use of military force against those responsible for $9 / 11$ and their aides. ${ }^{463}$ Shortly thereafter, the President ordered attacks on Afghanistan for the purpose of capturing Al Qaeda members and responding to the Taliban, which had given shelter to Osama bin Laden. ${ }^{464}$ On November 13, 2001, during the ongoing military campaign against the Taliban, President Bush issued a Military Order entitled, "Detention, Treatment, and Trial of Certain Non-Citizens in the War Against Terrorism." "465 This order provided for the military detention of noncitizens the President determined to be members of Al Qaeda, who engaged in terrorism and represented a threat to the United States. ${ }^{466}$ In the months following the U.S. invasion of Afghanistan, it came to light that the United States was transporting Afghan war captives to a military base in Guantanamo Bay,

authorization for the detention. Simply, the UCMJ recognizes the power of military commissions when they have proper jurisdiction. This is not meant to be a grant of authority to the President to convene a military tribunal for any reason. David Stoelting explains,

No U.S. statute permits military commissions to try terrorists. The statutory authority cited in the Military Order, Section 821 of the [UCMJ] does not state that military tribunals can be used to try terrorists. Instead, it simply preserves the well-established jurisdiction of military commissions over crimes as established by statute or by the laws of war.

David Stoelting, Military Commissions and Terrorism, 31 DenV. J. INT'L L. \& POL'y 427, 429 (2003).

460. See supra note 256.

461. Hamdi v. Rumsfeld, 542 U.S. 507, 516 (2004).

462. Id. at 517 .

463. The joint resolution was signed on Sept. 14, 2002. S.J. Res. 23, 107th Cong. (2001) (enacted).

464. Bush Announces Opening of Attacks, CNN.COM, Oct. 7, 2001, http://archives.cnn.com/2001/ US/10/07/ret.attack.bush/index.html.

465. Press Release, Office of the White House Press Secretary, President Issues Military Order (Nov. 13, 2001), available at http://www.whitehouse.gov/news/releases/2001/11/20011113-27.html. 466. Id. 
Cuba. $^{467}$ At that time, Congress passed no legislation ratifying or otherwise commenting on the presidentially ordered military detentions. ${ }^{468}$

In April 2002, the military discovered that Hamdi was a citizen and transferred him to military custody in the United States, but continued to hold him as an enemy combatant. ${ }^{469}$ Congress was again silent on the military detention of foreign nationals or U.S. citizen belligerents. ${ }^{470}$ Thus, Hamdi's case differed greatly from Hirabayashi and Korematsu, in which Congress had specifically ratified the President's executive orders and lesser officials' military policies regarding the Japanese. ${ }^{471}$ From a timing perspective, there is no evidence that the current Congress had military detentions in mind when it passed the AUMF, given that no such detentions had yet occurred.

467. Detainees began arriving at Guantanamo in January 2002. Security "Well at Hand" at Camp X-ray, CNN.COM, Jan. 12, 2002, http://archives.cnn.com/2002/US/01/12/gen.war.against. terror/index.html.

468. Interestingly, Congress has recently passed the "Ronald W. Reagan National Defense Authorization Act for Fiscal Year 2005," which is the first piece of legislation to contain language specifically addressing recent military detentions, including those in Guantanamo. Section 1091, entitled "Sense of Congress and Policy Concerning Persons Detained by the United States," provides in part,

It is the policy of the United States to ... ensure that, in a case in which there is doubt as to whether a detainee is entitled to prisoner of war status under the Geneva Conventions, such detainee receives the protections accorded to prisoners of war until the detainee's status is determined by a competent tribunal.

H.R. REP. NO. 4200, at $\S 1091$ (2004).

469. Hamdi v. Rumsfeld, 542 U.S. 507, 510 (2004).

470. The Fourth Circuit had mentioned that congressional authorization for Hamdi's detention could be inferred from an appropriations bill that provided funding for prisoners of war. The court stated, "Congress has specifically authorized the expenditure of funds for "the maintenance, pay, and allowances of prisoners of war [and] other persons in the custody of the [military] whose status is determined ... to be similar to prisoners of war." Hamdi v. Rumsfeld, 316 F.3d 450, 467-68 (2003), vacated 542 U.S. 507 (2004) (alteration in original) (quoting 10 U.S.C. § 956(5) (2002)). This statement, however, is generic language that has been in similar bills for years and in no way references Hamdi's particular detention or otherwise indicates that Congress meant to approve of the detention of U.S. citizens. Stephen Vladeck states,

To argue that $\S 956(5)$ authorizes the detention of U.S. citizens as enemy combatants is thus not only to argue that it authorizes the detention of anyone detained pursuant to a presidential proclamation, but also to argue that it rendered $\S 4001$ (a) moot, ab initio, for it is a contention that Congress, in enacting $\S 956(5)$ - and in codifying it in 1984delegated its entire detention authority to the President. If this is not an absurd result, what is?

Stephen I. Vladeck, Note, The Detention Power, 22 Yale L. \& Pol'Y ReV. 153, 189 (2004). Moreover, in Endo, the Court specifically rejected that the intent to allow the detention of loyal Japanese could be inferred from a lump appropriation. The lump appropriation at issue in Endo, unlike $\S 956(5)$, specifically referenced funding the relocation camps. Ex parte Endo, 323 U.S. 283, 304 n.24 (1944).

471. See supra notes 169-74 and accompanying text (discussing the legislative history of the Japanese restrictions). 
Turning to the language of the AUMF, the legislation is silent on military detention. ${ }^{472}$ The legislative history also fails to indicate that by passing the AUMF, Congress intended to authorize any military detention, much less the detention of U.S. civilians. ${ }^{473}$ In fact, some legislative history suggests that Congress was keenly aware of the differences between the AUMF and a declaration of war, which triggers presidential war powers. House Representative Conyers, for example, stated, "By not declaring war, the resolution preserves our precious civil liberties. This is important because declarations of war trigger broad statutes that not only criminalize interference with troops and recruitment but also authorize the President to apprehend 'alien enemies." "474

As a result, the Supreme Court was forced to engage in an incredible feat of interpretive grasping to find that the AUMF authorized Hamdi's detention. ${ }^{475}$ Bypassing both plain language and history, the Court asserted that given the background of the law of war, any authorization of military force must necessarily include endorsement of military detention, even citizen detention. ${ }^{476}$ Here, the Court appears to have relied on the interpretive canon that Congress is presumed to "legislate[] against [a] background of law, scholarship, and history." "477 To complete the argument, however, the Court needed to characterize the law, scholarship, and history of military detention power-and indeed power to detain citizens - as clear enough to compel the conclusion that by

472. Pub. L. No. 107-40, 115 Stat. 224 (2001).

473. See Vladeck, supra note 470, at 193 (noting "evidence in the legislative history that Congress explicitly meant to foreclose [the Bush Administration's] reading [of the AUMF]"). Justice Souter argued that provisions of the USA PATRIOT Act militated against a finding that Congress intended to approve of a Hamdi-type detention by passing the AUMF. He stated that considering that the USA PATRIOT Act

authorized the detention of alien terrorists for no more than seven days in the absence of criminal charges or deportation proceedings, [i]t is very difficult to believe that the same Congress that carefully circumscribed Executive power over alien terrorists on home soil would not have meant to require the Government to justify clearly its detention of an American citizen held on home soil incommunicado.

Hamdi, 542 U.S. at 551 (Souter, J., concurring) (internal citations omitted).

474. 147 Cong. Rec. H5638, H5680 (daily ed. Sept. 14, 2001) (statement of Rep. Conyers). See also id. at $\mathrm{H} 5673$ (statement of Rep. Wu) ("I would have strong reservations about a resolution authorizing the use of force in an open ended manner reaching far beyond responding to this specific terrorist attack on America. This is not that resolution.").

475. Hamdi, 542 U.S. at 518-20.

476. The Court stated,

We conclude that detention of individuals falling into the limited category we are considering, for the duration of the particular conflict in which they were captured, is so fundamental and accepted an incident to war as to be an exercise of the "necessary and appropriate force" Congress has authorized the President to use.

477. Nat'l Archives \& Records Admin. v. Favish, 541 U.S. 157, 169 (2004). 
enacting the AUMF, Congress intended to allow the executive to engage in such detentions. ${ }^{478}$ In attempting this characterization, the Court devoted a few paragraphs to discussing the importance of capturing and detaining enemies during war so that they do not return to the front line. ${ }^{479}$ In addition, to show that the law is well-settled on the issue of citizen detentions, the Court relied heavily on Quirin and In re Territo, a World War II case upholding the military detention of an American citizen fighting for Italy. ${ }^{480}$ Having surveyed the history of the law of war in this manner, the Court determined that "it is of no moment that the AUMF does not use specific language of detention" and concluded, "Because detention to prevent a combatant's return to the battlefield is a fundamental incident of waging war, in permitting the use of 'necessary and appropriate force,' Congress has clearly and unmistakably authorized detention in the narrow circumstances considered here."481 Having found "specific" congressional authorization for Hamdi's detention, the Court noted that it complied with the mandate of the Nondetention Act that citizens be detained only pursuant to an act of Congress. $^{482}$

There are several problems with the Court's treatment of legislative intent, beyond its disregard for both the plain language and legislative history of the AUMF. ${ }^{483}$ First, the question of citizen detention raises thorny constitutional issues - issues Congress is presumed to have intended to avoid. The plurality, however, completely ignored the canon of avoidance, which dictates that the "Court will not pass on the constitutionality of an Act of Congress if a construction of the statute is fairly possible by which the question may be avoided." 484 This canon "rest[s] on the reasonable presumption that Congress did not intend the

478. Hamdi, 542 U.S. at 518-20.

479. The Court stated, for example, that "[t]he capture and detention of lawful combatants and the capture, detention, and trial of unlawful combatants, by 'universal agreement and practice,' are 'important incident[s] of war," and "[t]he purpose of detention is to prevent captured individuals from returning to the field of battle and taking up arms once again." Id. at 518 (second alteration in original) (quoting Ex parte Quirin, 317 U.S. 1, 28, 30 (1942)).

480. In re Territo, 156 F.2d 142, 148 (9th Cir. 1946).

481. Hamdi, 542 U.S. at 519

482. Id. at 516-18. But see id. at 574 (Scalia, J., dissenting) ("I do not think this statute even authorizes detention of a citizen with the clarity necessary ... to overcome the statutory prescription that "[n]o citizen shall be imprisoned or otherwise detained by the United States except pursuant to an Act of Congress."') (quoting 18 U.S.C. § 4001(a) (alteration in original) (citations omitted)).

483. See id. at 573-74 (Scalia, J., dissenting) (arguing that the AUMF did not contain language specific enough to comport with the dictates of cases like Endo).

484. United States v. Clark, 445 U.S. 23, 27 (1980). See also New York City Transit Auth. v. Beazer, 440 U.S. $568,582 \&$ n.22 (1979) (holding that a court must first use a plain meaning construction) 
alternative which raises serious constitutional doubts." ${ }^{\text {"45 }}$ In Hamdi, however, the Court found congressional assent from silence ${ }^{486}$ and went on to painstakingly analyze the constitutionality of the military procedures governing Hamdi's case. ${ }^{487}$

Possibly even more problematic is the Court's brief and simplistic treatment of the history of detentions, especially citizen detentions, ${ }^{488}$ to conclude that it is well settled that authorizations of force always approve military detention of citizens. The Court's reliance on the purported axiomatic nature of the need to temporarily detain enemy combatants to prevent them from rejoining enemy forces is troubling in light of the fact, discussed earlier, that U.S. citizens who fight for an enemy are subject to criminal penalties. ${ }^{489}$ Moreover, the relative paucity of the number of cases on citizen detentions, the fact that the two major cases on the issue, Milligan and Quirin, plainly conflict, ${ }^{490}$ and the tomes of legal literature discussing the constitutional difficulties with wartime detention of citizens ${ }^{491}$ show that the legal history on this issue is far from clear. The plurality, however, dismissed outright any interpretive

485. Clark v. Suarez Martinez, 125 S. Ct. 716, 724 (2005).

486. See Hamdi, 542 U.S. at 574 (Scalia, J., dissenting) ("I do not think this statute even authorizes detention of a citizen with the clarity necessary to satisfy the interpretive canon that statutes should be construed so as to avoid grave constitutional concerns.").

487. See id. at 532 (majority opinion) ("Striking the proper constitutional balance here is of great importance to the Nation during this period of ongoing combat. But it is equally vital that our calculus not give short shrift to the values that this country holds dear or to the privilege that is American citizenship.").

488. To dispose of the citizenship issue, the Court simply cited Quirin and concluded that there was "no bar to this Nation's holding one of its own citizens as an enemy combatant." Id. at 519. The Court further stated,

A citizen, no less than an alien, can be "part of or supporting forces hostile to the United

States or coalition partners" and "engaged in an armed conflict against the United

States[;]" such a citizen, if released, would pose the same threat of returning to the front during the ongoing conflict.

Id. (emphasis added) (citation omitted).

489. Justice Scalia stated that military detention, as described by the plurality "is probably an accurate description of wartime practice with respect to enemy aliens. The tradition with respect to American citizens, however, has been quite different. Citizens aiding the enemy have been treated as traitors subject to the criminal process." Id. at 559 (Scalia, J., dissenting).

490. See id. at 572 (stating that "[t] he plurality's claim that Quirin's one-paragraph discussion of Milligan" is a clear disavowal of Milligan's principles "defies logic").

491. See, e.g., Christopher Bryant \& Carl Tobias, Quirin Revisited, 2003 WIS. L. REV. 309, 330 ("A number of considerations warrant restricting the opinion in Quirin."); Rostow, supra note 340 (analyzing constitutional dimension of internment cases); Turley, supra note 71, at 685 ("[T] Court has viewed the exercise of military jurisdiction over citizens as inimical to basic constitutional guarantees."); White, supra note 454 (discussing constitutional issues in Quirin); Vladeck, supra note 470, at 195 (asserting that the executive does not have power to militarily detain citizens); Ingrid Brunk Wuerth, The President's Power to Detain "Enemy Combatants": Modern Lessons from Mr. Madison's Forgotten War, 98 Nw. U. L. REV. 1567, 1569 (2004) (arguing "that the President lacks the constitutional power to detain U.S. citizens as enemy combatants"). 
importance of Milligan, noting that "Quirin was a unanimous opinion. It both postdates and clarifies Milligan, providing us with the most apposite precedent that we have on the question of whether citizens may be detained in such circumstances." ${ }^{492}$ The Court, of course, made no mention of the particular circumstances of Quirin or its disanalogies to Hamdi's situation. ${ }^{493}$

A bigger problem is that the Court seems to have conflated the issue of the current state of the law, as evidenced by Quirin's precedential value, with the issue of whether the state of the law is sufficiently unambiguous that legislative intent can be established by its mere existence. Let us agree with the Supreme Court for the moment that Quirin and not Milligan represented the true state of the law when Congress enacted the AUMF. Under this view, the law permitted the President to order military detention of U.S. citizen enemy combatants during a declared war and with the assent of Congress. ${ }^{494}$ Even if that much were clear, until the Hamdi decision itself, it was not apparent that the law permitted the President to possess such power without specific legislation and in the absence of a declared war. ${ }^{495}$ Of course, the Supreme Court has now expanded Quirin to serve as precedent for the proposition that the President has the power to detain citizens in the absence of specific legislation and a declaration of war. Even accepting this expansive interpretation of Quirin, there is not the slightest amount of evidence that, when passing the AUMF, Congress had interpreted Quirin in this manner and purposefully neglected to mention military detentions (although it meant to authorize them) because it believed that, pursuant to Quirin, the President did not need its explicit consent. ${ }^{496}$ The plurality must make this precise assumption to complete its argumentan assumption that is far fetched at best and disingenuous at worst. ${ }^{497}$

492. Hamdi, 542 U.S. at 523 .

493. Justice Scalia observed, "The plurality rejects any need for 'specific language of detention' on the ground that detention of alleged combatants is a 'fundamental incident of waging war.' Its authorities do not support that holding in the context of the present case." Id. at $574 \mathrm{n} .5$ (Scalia, J., dissenting) (citation omitted). See also supra notes 341-63 and accompanying text (discussing differences between Quirin and Hamdi).

494. See Hamdi, 542 U.S. at 522 ("Even accepting that [Milligan] once could have been viewed as standing for the sweeping proposition for which Justice Scalia cites them-that the military does not have authority to try an American citizen accused of spying against his country during wartime-Quirin makes undeniably clear that this is not the law today.").

495. See supra notes 452-59 and accompanying text (discussing how Quirin involved both a declared war and specific legislation).

496. See supra notes $475-76$ and accompanying text (discussing the legislative history of the AUMF).

497. Indeed, the plurality did not mention the legislative history of the AUMF even once. 
Thus, like the internment cases, Hamdi did not grant unilateral authority to the President to detain citizens militarily. Unlike the internment cases, however, it expanded the President's ability to act without specific congressional approval. In the internment cases, the Court was careful to make sure that Congress did actually consent, not just to the war in general, but to the specific policies at issue in the cases. The Court in Hamdi did nearly the opposite. Rather than trying to ascertain the true intent of Congress, the Court was determined to find congressional assent by hook or crook so as to avoid addressing the problematic issue of executive unilateralism. In attempting to avoid the issue, however, the Court generously bolstered the executive's power. The Court set up a precedent whereby the President may unilaterally initiate a program of citizen detention, which is constitutional so long as there has at some point been congressional authorization of military force against those with whom the citizen is alleged to be a sympathizer. To the extent that executive unilateralism often goes hand in hand with the restriction of rights, by bolstering the executive's power to act without Congress, Hamdi cannot be said to represent civil libertarian progress. ${ }^{498}$

\section{Individual Process}

Having decided that the President had authority to detain citizen enemy combatants and that the AUMF provided adequate congressional support, the Court turned to the issue of the process due to citizens so detained. The decision here is likely what has heartened civil libertarians. ${ }^{499}$ The Court, rather than issuing vague warnings against military overreaching as in the internment cases, articulated specific

498. Professors Samuel Issacharoff and Richard H. Pildes characterize executive unilateralists and civil libertarians as polarized factions:

Executive unilateralists are advocates of national security [who] conclude that unilateral executive discretion, not subject to oversight from other institutions, is required. On the other side are what might be called civil libertarian idealists. Advocates of this view sometimes deny, to themselves or to their audiences, that shifts in the institutional frameworks and substantive rules of liberty/security tradeoffs do, indeed, regularly take place during times of serious security threats . . . .

Samuel Issacharoff \& Richard H. Pildes, Between Civil Libertarianism and Executive Unilateralism: An Institutional Process Approach to Rights During Wartime, 5 THEORETICAL INQUIRIES L. 1, 4 (2004).

499. See Jenny S. Martinez, International Decision, Hamdi v. Rumsfeld, 124 S. Ct. 2633 (2004), 98 AM. J. INT'L L. 782, 785 (David D. Caron ed., 2004) (“The Supreme Court's decision in Hamdialong with its decision to exercise jurisdiction over the Guantánamo detainees in Rasul v. Bush-is a sharp and much needed rebuke to the U.S. government's position that its treatment of detainees in the so-called 'war on terrorism' is immune from judicial oversight."); see also supra note 35 (describing how Hamdi was considered a civil libertarian victory). 
operational due process limits on military discretion. ${ }^{500}$ Despite the government's urging that the Court could only examine the government's bases for the overall detention scheme, the Court went much further and articulated the process due to each individual detained as an enemy combatant. ${ }^{501}$ In the internment cases, on the other hand, the Court focused not on the individual process involved in any given detention, but solely on whether the larger restrictive scheme was within the proper exercise of military discretion. ${ }^{502}$ This divergence between the internment cases and the terrorism cases appears to lend credence to the argument that the law has progressed. Naturally, it seems more progressive to engage in judicial review of both the government's purported bases for the detention scheme and the details of the government's procedures rather than solely focusing on the bases. ${ }^{503}$

This "progression," however, may have less to do with a civil libertarian movement of the Court and more with the factual differences between the military programs at issue in Hamdi and the internment cases. In the internment cases, the restrictions applied overtly to a racial category, ${ }^{504}$ whereas in Hamdi the detention scheme applied to a conduct-based category, namely those who "fight" for the enemy. ${ }^{505}$ Because of the use of a nefarious racial proxy for dangerous conduct, ${ }^{506}$ the issue of individualized process was rendered relatively unimportant in the internment cases. The category to which one needed to belong was "Japanese" and there was hardly a need for individualized hearings on whether a given person was Japanese. ${ }^{507}$ Had the government based

500. Hamdi v. Rumsfeld, 542 U.S. 507, 532-34 (2004).

501. Id. at 533-34.

502. See Korematsu v. United States, 323 U.S. 214, 217-18 (1944) (citing and discussing Hirabayashi); Hirabayashi v. United States, 320 U.S. 81, 93 (1943) (holding that courts cannot review whether Congress was justified in excluding Japanese Americans from the West Coast).

503. Interestingly, the Court in Hamdi looked only at the procedures and not at the purported bases for the larger detention scheme, seeming to assume the larger program of detaining citizen "enemy combatants" needed no specific justification so long as conflict existed. See supra notes 297-300 and accompanying text.

504. See Hirabayashi, 320 U.S. at 88 ("[T]he present situation requires ... the establishment of certain regulations pertaining to all enemy aliens and all persons of Japanese ancestry . ..."); supra notes 49-58 and accompanying text (discussing racialized bases for the internment).

505. See Hamdi, 542 U.S. at 516 (confining the issue to the constitutionality of detaining a person who "was part of or supporting forces hostile to the United States or coalition partners in Afghanistan and who engaged in an armed conflict against the United States" (internal quotations omitted)).

506. Justice Murphy consistently criticized the racial basis for the Japanese internment. See Ex parte Endo, 323 U.S. 283, 307 (1944) (Murphy, J., concurring) (stating that Endo's detention was "another example of the unconstitutional resort to racism inherent in the entire evacuation program").

507. During the internment, other ethnic Asian groups were careful to differentiate themselves 
the restrictions on disloyalty rather than race, there would have been an important issue of the detainee's opportunity to challenge her classification as disloyal. ${ }^{508}$ One signal of social progress, then, might be in the race category. At the very least, the Bush Administration was uncomfortable with overtly basing detention on race rather than conduct. ${ }^{509}$

Basing detention classification on conduct, however, only reigns in the government's power to incarcerate if there is a meaningful avenue for a detainee to challenge the allegation that he engaged in the qualifying conduct. If the Executive, without challenge, could designate anyone an enemy combatant, the detention power would prove to be broader even than during the internment, where detention was limited by race. Although the government had urged just such a position, ${ }^{510}$ the Hamdi

from the Japanese. Frank Wu explains, "Chinese Americans and Korean Americans did their best to distinguish themselves from Japanese Americans. They posted signs and wore buttons that read, 'Chinese, not Japanese' and 'I hate the Japs more than you do.'" Frank H. Wu, Profiling in the Wake of September 11: The Precedent of the Japanese American Internment, CRIM. JUST., Summer 2002, at 52, 53. Natsu Saito Taylor details a disturbing Time Magazine article entitled "How to Tell Your Friends From the Japs," which stated,

"Virtually all Japanese are short. Japanese are likely to be stockier and broader-hipped than short Chinese. Japanese are seldom fat; they often dry up and grow lean as they age. Although both have the typical epicanthic fold of the upper eyelid, Japanese eyes are usually set closer together. The Chinese expression is likely to be more placid, kindly, open; the Japanese more positive, dogmatic, arrogant. Japanese are hesitant, nervous in conversation, laugh loudly at the wrong time. Japanese walk stiffly erect, hard heeled. Chinese, more relaxed, have an easy gait, sometimes shuffle."

Natsu Taylor Saito, Model Minority, Yellow Peril: Functions of "Foreignness" in the Construction of Asian American Legal Identity, 4 AsIAN L.J. 71, 83 (1997) (quoting RONALD TAKAKI, STRANGERS From A DIFFERENT SHORE: A HISTORY OF ASIAN AMERICANS 370 (1989)).

Moreover, the Japanese were generally compliant with the internment orders and did not seek to challenge or hide their "Japanese-ness." See supra notes 5-6 and accompanying text (explaining that many Japanese prided themselves on being cooperative). By exception, Fred Korematsu had made an unsuccessful attempt to hide his Japanese features by getting plastic surgery. Korematsu v. United States, 140 F.2d 289, 293 (1943) (Denman, J., concurring), aff'd, 323 U.S. 214 (1944).

508. Indeed, the Court later held that detention of a loyal citizen was impermissible. Endo, 323 U.S. at 302-04. It resolved this issue, however, on nonconstitutional grounds. Supra notes 226-28 and accompanying text.

509. As others have mentioned, there is a racial element to the Bush terrorism policies, supra notes 95-97 and accompanying text, but because that racial element was not raised by the parties, it was not an issue for adjudication. Supra note 156.

510. This was precisely the Bush Administration's position regarding Hamdi. The government asserted that Hamdi had no right to meet with an attorney or challenge his individual detention in court. As to judicial review, the government argued that a "court's inquiry should come to an end once the military has shown in the return that it has determined that the detainee is an enemy combatant." Brief for Respondents-Appellants at *11, Hamdi v. Rumsfeld, 296 F.3d 278 (4th Cir. 2002) (No. 02-6895), available at 2002 WL 32728567. As to counsel, the government stated, "it is well-settled that the military has the authority to capture and detain individuals whom it has determined are enemy combatants in connection with hostilities in which the Nation is engaged, including enemy combatants claiming American citizenship." Id. at *10. Even Japanese detained in the internment had some opportunity to prove their loyalty and apply for a release. See Endo, 323 
decision provided detainees some ability to challenge the government's classification. ${ }^{511}$ Using the balancing test from Mathews v. Eldridge, ${ }^{512}$ a case involving deprivation of social security benefits, the Court determined that detainees were entitled under due process to some ability to rebut the government's claim that they were enemy combatants. ${ }^{513}$ The government, however, enjoys a presumption of accuracy in its classification and may base the classification on unsupported hearsay documents like the Mobbs Declaration. ${ }^{514}$

Does this show progress? In some sense, yes. If the government were to use the enemy combatant category to sweep thousands of Arab Americans into military detention asserting that they aided Al Qaeda, Hezbollah, the Taliban, insurgents in Iraq, or other disfavored groups, at least those detainees would have some ability to challenge their statuses as enemy combatants. Remember, however, that internment policies technically allowed the Japanese to demonstrate their loyalty and apply for release. ${ }^{515}$ For the Japanese, this was an option, but largely an unexercisable option. ${ }^{516}$ Likewise, for potential terrorism detainees, it is a near impossible hurdle for a military detainee (especially if there are thousands) to overcome a presumption of enemy status and disprove conclusory hearsay statements, ${ }^{517}$ particularly if such statements involve

\footnotetext{
U.S. at 291-93 (describing the leave application process).

511. Hamdi v. Rumsfeld, 542 U.S. 507, 533 (2004).

512. 424 U.S. 319,335 (1976).

513. Hamdi, 542 U.S. at 532-33.

514. See id. at 533-34 (stating that to reduce the burden upon an engaged military, the government may enjoy a rebuttable presumption in favor of its evidence, which may include hearsay); see also supra note 245 (Mobbs Declaration).

515. See Endo, 323 U.S. at 291-93 (describing the leave application process).

516. Christine Ann Lobasso describes the failings of the internment leave process and reaches the following conclusion:

This process did not operate to assess whether or not there was a necessity for the individual's detention. Rather, it operated to assess whether or not the individual was worthy enough to be released. Hence we see a total failure of the initial procedure that is guaranteed to an individual who is deprived of his right to liberty.

Christine Ann Lobasso, Elevation of the Individual: International Legal Issues that Flow from the American Internment of the West Coast Japanese During World War II, 8 TOURO INT'L L. REV. 45, 89 (1998)

517. The difficulty in overcoming a presumption of dangerousness is exemplified by criminal defendants who attempt to challenge a dangerousness presumption under the Bail Reform Act. See generally John A. Washington, Note, Preventive Detention: Dangerous Until Proven Innocent, 38 CATH. U. L. REV. 271 (1988) (arguing that a dangerousness presumption runs counter to a desire to protect the innocent). The War on Terror's use of preventive detention puts an even harder burden on the detainee as mere criminal danger is elevated to danger of ultimate acts of terror. See Laurie L. Levenson, Detention, Material Witnesses \& the War on Terrorism, 35 LoY. L.A. L. REV. 1217, 1220 (2002) (noting the trend toward acceptance of preventive detention in the post-9/11 world).
} 
purportedly sensitive terrorism intelligence. ${ }^{518}$ Scholars invoke the internment precisely to illustrate the problem with conclusory "military judgment." Ev19 Even in the face of the process crafted in Hamdi, the government may proceed with detention upon evidence as conclusory as the Mobbs Declaration. ${ }^{520}$ Hence, Professor Chris Iijima appears to be correct in characterizing as "chillingly prophetic" 521 Justice Jackson's criticism that the Korematsu majority justified detention on the basis of

518. The difficulty in challenging the government in its terrorism decisions is exemplified by the Zacarias Moussaoui case. United States v. Moussaoui, 282 F. Supp. 2d 480 (E.D. Va. 2003), aff'd in part, vacated in part, 365 F.3d 292 (4th Cir. 2004), amended on reh'g by 382 F.3d 453 (4th Cir. 2004). Moussaoui attempted to defend against charges that he was involved in the $9 / 11$ attacks. The judge who presided over his case

several times ... expressed her concern that the government may be denying Moussaoui information that could assist him as he represents himself. She ... questioned whether Moussaoui could receive a fair trial in open court, given the government's secrecy, and reminded prosecutors of their obligation to turn over material that could aid the defense.

Feds: Moussaoui Judge Out of Bounds, CBSNews.COM, Apr. 24, 2003, http://www.cbsnews.com/ stories/2002/07/22/attack/main515896.shtml. Also illustrative is the military process currently afforded to Guantanamo detainees, in which the government may rely on classified information. In finding these proceedings to violate due process, the district court in In re Guantanamo Detainee Cases excerpted testimony from a tribunal:

Tribunal President: Did you know of anybody that was a member of Al Qaida?

$$
\cdots
$$

Detainee: No. This is something the interrogators told me a long while ago. I asked the interrogators to tell me who this person was. Then I could tell you if I might have known this person, but not if this person is a terrorist. Maybe I knew this person as a friend. Maybe it was a person that worked with me. Maybe it was a person that was on my team. But I do not know if this person is Bosnian, Indian or whatever. If you tell me the name, then I can respond and defend myself against this accusation.

$$
\text { ... }
$$

Detainee: That is it, but I was hoping you had evidence that you can give me. If I was in your place - and I apologize in advance for these words - but if a supervisor came to me and showed me accusations like these, I would take these accusations and I would hit him in the face with them. Sorry about that.

[Everyone in the Tribunal room laughs.]

Tribunal President: We had to laugh, but it is okay.

Detainee: Why? Because these are accusations that I can't even answer. I am not able to answer them. You tell me I am from Al Qaida, but I am not an Al Qaida. I don't have any proof to give you except to ask you to catch Bin Laden and ask him if I am a part of Al Qaida. To tell me that I thought, I'll just tell you that I did not. I don't have proof regarding this. What should be done is you should give me evidence regarding these accusations because I am not able to give you any evidence. I can just tell you no, and that is it.

355 F. Supp. 2d 443, 469-70 (D.D.C. 2005).

519. See supra notes $36-37$ and accompanying text (noting some scholars use the example of the internment to criticize the Bush Administration's detaining of individuals without process).

520. See supra note 245 and accompanying text (Mobbs Declaration).

521. Iijima, supra note 13, at 124. 
an "unsworn, self-serving statement, untested by any crossexamination." 522

\section{E. Scope of War Powers: Nature and Length of Military Detention}

Even after the Supreme Court had taken the rights-restricting view that the President may detain U.S. citizens militarily in the absence of a declared war and explicit congressional approval, it still could have made some progressive choices regarding the character and length of the detention. Unfortunately, these choices also cannot be said to represent progress from the internment cases.

\section{Character of Detention}

As illustrated in the introduction, the Japanese internees suffered greatly, and the repercussions of their bondage linger. ${ }^{523}$ While quite horrible, their incarceration conditions were not nearly as deplorable as those of detainees in the War on Terror. Detainees like Hamdi, Padilla, and those in Guantanamo have been held in conditions worse than those of convicted criminals. ${ }^{524}$ They have been held, not in barracks or temporary houses, but rather in jails, locked down, incommunicado, and unable to see family. ${ }^{525}$ The Guantanamo prisoners have even been

522. Korematsu v. United States, 323 U.S. 214, 245 (1944) (Jackson, J., dissenting).

523. See supra notes 4-8 and accompanying text (describing Japanese Americans' pervasive suffering).

524. Hamdi, for example, was placed at the Naval Brig in Norfolk Virginia. He was not, however, treated like the rest of the inmates, who were military criminals. Rather, "Hamdi was kept in one of the brig's two solitary confinement cells [which the Commander] declined to show ... or discuss." Matthew Dolan, No Ordinary Jail. The Military Brig at Norfolk Naval Station-Holds 145 Prisoners, but its Operations are Almost Completely Secret, THE VIRGINIAN-PILOT, February 23, 2004, at A1. The International Committee of the Red Cross (ICRC) has documented the particular negative effect of detention on terrorism detainees because of the uncertainty of the length and status of their detention. The ICRC has " observed what [it] consider[s] to be a worrying deterioration in the psychological health of a large number of the internees' because of the uncertainty of their situation." Red Cross: Deteriorating Conditions at Guantanamo, CNN.COM, October 10, 2003, http:/edition.cnn.com/2003/WORLD/americas/10/10/redcross.guantanamo.ap/ (quoting ICRC spokesman Florian Westphal).

525. Even after the district court granted Padilla access to counsel, information was severely restricted.

[T] he military made sure the meeting would be virtually useless to Padilla: It barred the two lawyers from telling the court, the public or even the rest of their legal team anything Padilla told them. The government, however, held a news conference weeks later, claiming Padilla had planned to blow up apartment buildings using natural gasallegations that Padilla had no chance to hear, much less answer. 
detained in cage-like cells. ${ }^{526}$ Both the internment cases and the terrorism cases allowed the government to place military restrictions on its own citizens. Each Court had a choice, however, as to how much hardship those restrictions would place on the individuals. The question is whether the Court in Hamdi made a more progressive choice than in the internment cases.

In understanding this choice, some background to jurisprudential limits on the character of noncriminal detention is helpful. The Court has permitted detention outside the protections of the criminal process in a limited category of cases, ${ }^{527}$ including cases involving civil commitment of the mentally ill or pedophiles, ${ }^{528}$ quarantine of disease carriers, ${ }^{529}$ and detention of aliens pending deportation. ${ }^{530}$ The constitutionality of such detentions, however, has been premised on the fact that such detentions were not punitive in nature but rather necessary to serve a public need. ${ }^{531}$ Similarly, the Hamdi plurality reasoned that Hamdi's detention was justified on the grounds of military necessity and not on punishment. ${ }^{532}$ The Court stated, "Captivity is neither a punishment nor an act of vengeance,' but 'merely a temporary detention which is devoid of all penal character.",

526. Hamdi described his conditions in Guantanamo as follows: "It was a jail for slow death, especially since it's located in an area that's unbearably humid and is like a cage for animals and not a prison for humans." Saudi-American Speaks Out on Confinement, AssocIATED PRESS, Oct. 16, 2004.

527. The Court has opined,

Freedom from imprisonment-from government custody, detention, or other forms of physical restraint - lies at the heart of the liberty [the Due Process] Clause protects. And this Court has said that government detention violates that Clause unless the detention is ordered in a criminal proceeding with adequate procedural protections or in certain special and "narrow" nonpunitive "circumstances."

Zadvydas v. Davis, 533 U.S. 678, 690 (2001) (citations omitted).

528. E.g., Kansas v. Hendricks, 521 U.S. 346 (1997); Allen v. Illinois, 478 U.S. 364 (1986)

529. E.g., R.R. Co. v. Husen, 95 U.S. 465 (1877).

530. E.g., Wong Wing v. United States, 163 U.S. 228 (1896).

531. The Court in Hendricks allowed civil confinement because the state had disavowed any punitive intent; limited confinement to a small segment of particularly dangerous individuals; provided strict procedural safeguards; directed that confined persons be segregated from the general prison population and afforded the same status as others who have been civilly committed; recommended treatment if such is possible; and permitted immediate release upon a showing that the individual is no longer dangerous or mentally impaired.

Hendricks, 521 U.S. at 368-69.

532. See Hamdi v. Rumsfeld, 542 U.S. 507, 518-19 (2004) (“"'The object of capture is to prevent the captured individual from serving the enemy. He is disarmed and from then on must be removed as completely as practicable from the front, treated humanely, and in time exchanged, repatriated, or otherwise released."' (quoting In re Territo, 156 F.2d 142, 145 (9th Cir. 1946))).

533. Id. (quoting Territo, 156 F.2d at 145). 
In assessing the constitutionality of such detentions, the Court has addressed what limitations must be placed on noncriminal detention to differentiate it from punishment. The conservative answer to this question is that civil detention may look and feel exactly like criminal punishment so long as the state articulates a reason for the detention outside of retribution or deterrence. ${ }^{534}$ The most progressive stance on this issue is that civil detention must be wholly different from criminal incarceration. ${ }^{535}$

The Supreme Court has indicated in the past that noncriminal detention should be materially different from the incarceration of convicted criminals. In Allen v. Illinois, the Court upheld a statute providing for the civil commitment of certain sexual offenders by finding the detention civil in nature. ${ }^{536}$ Essential to this finding was the fact that the civilly detained individuals were treated differently from the ordinary criminal. The Court observed that it may have struck down the statute "[h]ad petitioner shown, for example, that the confinement of such persons imposes on them a regimen which is essentially identical to that imposed upon felons." 537 The Court also noted that "counsel for the State assures us that under Illinois law sexually dangerous persons must not be treated like ordinary prisoners. ${ }^{, 538}$

The more recent case of Seling $v$. Young ${ }^{539}$ seems to point to a shift away from differentiating the character of noncriminal confinement from that of criminal punishment. Specifically, the Court ruled in Seling that it would not entertain an as-applied challenge to a civil commitment statute previously determined to be nonpunitive in nature, based on the petitioner's claim that his actual conditions of confinement were indistinguishable from criminal conditions. ${ }^{540}$ The Court did leave room for the possibility, however, that the actual conditions of the civil confinement could be essential to an initial determination that the detention regime was a facially valid civil regulation rather than

534. This approach is exemplified by Justice Scalia's concurrence in Seling v. Young, 531 U.S. 250, 267-68 (2001) (Scalia, J., concurring), which states that the character of detention can never bear on the question of the true purpose of the purportedly civil detention statute.

535. Justice Stevens has adopted such an approach to the constitutionality of civil detention of sex offenders: "A goal of treatment is not sufficient, in and of itself, to render inapplicable the Fifth Amendment, or to prevent a characterization of proceedings as "criminal." Allen v. Illinois, 478 U.S. 364, 380 (Stevens, J., dissenting).

536. Id. at 364 (majority opinion).

537. Id. at 373 .

538. Id. at 374 .

539. 531 U.S. 250 (2001).

540. Id. at 266. 
unconstitutional criminal punishment. ${ }^{541}$ Justice Scalia adopted a more conservative position and objected to the view that the constitutionality of a civil detention statute, even in the first instance, depends on the nature of the actual detention, arguing instead that the actual nature of the petitioner's confinement is always irrelevant. ${ }^{542}$ Justice Stevens's dissent in Seling reflects the most progressive approach to this particular issue. He argued that the Court had "consistently looked to the conditions of confinement as evidence of both the legislative purpose behind the statute and its actual effect." question whether a statute is in fact punitive cannot always be answered solely by reference to the text of the statute." 544

The internment cases, as mentioned before, represent judicial abdication on the issue of detention all together. ${ }^{545}$ Consequently, because the majority court ignored that detention had taken place, it could hardly pass on any conditions of that detention. The few passages in Korematsu that reference detention evidence a deliberate minimization of the burdens of military detention. ${ }^{546}$ The Court scoffed at the notion that the relocation camps could be called "concentration camps" and indicated rather that they were innocuous temporary relocation shelters. ${ }^{547}$ Thus, although affording no relief to the Japanese at the time, the Court did not forge into law approval of detention in camps, much less approval of outright incarceration and its attendant conditions.

The Hamdi Court, on the other hand, did precisely this. By overtly approving Hamdi's incarceration, the Court constitutionally cemented the government's ability, not only to detain its own citizens for military reasons, but also to detain them like criminals. ${ }^{548}$ While characterizing

541. Id. at $266-67$.

542. Id. at 274 (Scalia, J., concurring). Even he conceded, however, that the Court possessed some leeway to analyze "effects apparent upon the face of the [civil commitment] statute." Id. at 269.

543. Id. at 275 (Stevens, J., dissenting).

544. Id.

545. See supra notes 60-64 and accompanying text (noting some academics believe the internment cases stand for the principle of judicial abstention).

546. Korematsu v. U.S., 323 U.S. 214, 223 (1944).

547. Id.

548. Although the Court did not put an explicit stamp of approval on the conditions of Hamdi's incarceration, once the Court upheld Hamdi's detention, his possibility of challenging the conditions of that detention was greatly reduced. The public internalizes judicial approval of incarceration, reducing the viability of any future challenge to the detention. Laurie Levenson explains how the public internalized the concept of preventive detention after United States v. Salerno, 481 U.S. 739 (1987), in which the Court upheld pretrial detention. She states that Salerno

fundamentally changed how the criminal justice system views detention-a change that reverberates in the War on Terrorism today. Up to that time, there had been a 
Hamdi's detention as a temporary measure solely designed to prevent him from returning to the enemy ${ }^{549}$ rather than for retribution, the Court said absolutely nothing about the conditions of Hamdi's detention or whether that detention may be exactly like criminal punishment. The Court merely remained silent in the face of the indisputable fact that Hamdi was being held in a jail like a criminal.

Notably, the Geneva Convention lays out the conditions of internment of combatants detained for the express purpose of preventing their return to the enemy. Article 22 of the Convention expressly prohibits the incarceration of prisoners of war, "[e]xcept in particular cases which are justified by the interest of the prisoners themselves, they shall not be interned in penitentiaries." ${ }^{\text {S50 }}$ Article 22 further provides,

The Detaining Power shall assemble prisoners of war in camps or camp compounds according to their nationality, language and customs, provided that such prisoners shall not be separated from prisoners of war belonging to the armed forces with which they were serving at the time of their capture, except with their consent.

In addition, the Convention provides that "[p]risoners of war shall be quartered under conditions as favourable as those for the forces of the Detaining Power who are billeted in the same area." 552 The Convention also specifies other positive detention conditions, including, among other things, that detainees receive advance pay, ${ }^{553}$ have access to a canteen in which to purchase products at market price, ${ }^{554}$ be permitted to receive outside money, ${ }^{555}$ and have the ability to manage personal funds ${ }^{556}$ and receive personal packages. ${ }^{557}$ Such provisions, taken together, emphasize the idea that prisoners of war are not being punished for fighting with the enemy. Rather, they are detained as a temporary

presumption that a defendant should not be prejudged as a threat to security. Salerno altered that. We moved into an era in which there might technically be a presumption of innocence, but there are a host of criminal and civil laws that allow the government to detain individuals because it suspects they could cause future harm.

Levenson, supra note 517, at 1218 .

549. Hamdi v. Rumsfeld, 542 U.S. 507, 518-19 (2004).

550. Geneva Convention Relative to the Treatment of Prisoners of War, art. 22, Oct. 21, 1950, 75 U.N.T.S. 135 [hereinafter Geneva Convention] (emphasis added).

551. Id.

552. Geneva Convention, supra note 550, art. 25.

553. Geneva Convention, supra note 550, art. 60.

554. Geneva Convention, supra note 550, art. 28.

555. Geneva Convention, supra note 550, art. 64-65.

556. Geneva Convention, supra note 550, art. 65.

557. Geneva Convention, supra note 550, art. 71. 
measure to prevent the enemy from gaining a tactical advantage, and thus prisoner-of-war detention should resemble field living conditions of U.S. military personnel. ${ }^{558}$

Obviously, the government has not complied with any of these dictates in its treatment of Hamdi, Padilla, or the Guantanamo detainees. Hamdi and Padilla, perhaps as a product of the nonparadigmatic nature of their capture, were separated from members of the forces with whom they were alleged to have associated, stripped of their customs, and held in jail. ${ }^{559}$ While such incarceration might be justified if Hamdi and Padilla were dangerous criminal defendants who posed a risk of flight, ${ }^{560}$ the government has insisted that the nature of the detentions is not criminal, and the Court expressly ruled that Hamdi's detention was justified solely by military necessity. ${ }^{561}$ The Court, however, did not state that Hamdi's military detention must accord with the dictates of the Geneva Convention. ${ }^{562}$ Obviously, the Court was not unaware that Hamdi had been detained in a jail, in lockdown condition, without any access to family. ${ }^{563}$ By endorsing such detention, without qualification, the Court implicitly adopted the more conservative view that military detention could be as, or more, severe than criminal incarceration.

\section{Length of Detention}

In addition, the Hamdi Court adopted an interpretation of "wartime" that greatly increased the chances of individuals being detained indefinitely. Before Hamdi, the Supreme Court recognized that when an

558. See Geneva Convention, supra note 550, art. 24 ("Transit or screening camps of a permanent kind shall be fitted out under conditions similar to those described in the present Section, and the prisoners therein shall have the same treatment as in other camps.").

559. See Hamdi v. Rumsfeld, 542 U.S. 507, 518-21 (2004) (describing conditions in which detainees are held).

560. Criminal defendants who are a flight risk or dangerous may be detained prior to a trial. The decision to detain defendants, however, must be made after a contested hearing in which the government proves by clear and convincing evidence that no other conditions or combination of conditions will assure their presence at trial or the safety of society. United States v. Salerno, 481 U.S. 739, 747 (1987).

561. Hamdi, 542 U.S. at 521

562. The Court only mentioned the Geneva Convention as support for the proposition that the law of war permits temporary detention of prisoners of war. Hamdi, 542 U.S. at 520. While relying on the Geneva Convention to establish the legality of Hamdi's detention, the Court provided none of the safeguards required by the Geneva Convention. Justice Souter concluded that the government's treatment of Hamdi likely violated its provisions. See id. at 549 (Souter, J., concurring) ("[T]he Government obviously has not been treating him as a prisoner of war, and in fact the Government claims that no Taliban detainee is entitled to prisoner of war status. This treatment appears to be a violation of the Geneva Convention ...." (internal citation omitted)).

563. See supra Part III.B.2 (discussing Hamdi’s case). 
individual was detained because of an emergency of a determinate length, his detention must be limited in duration. For example, the Court held that quarantine may last only as long as necessary for the risk of disease to pass. ${ }^{564}$ In United States v. Salerno, the Court approved of pretrial detention for dangerousness because the length of such detention was limited by effective speedy trial laws. ${ }^{565}$

The legal duration of war for the purpose of exercising war powers has been the subject of much historical debate. In the World War II case of Ludecke v. Watkins, ${ }^{566}$ the Supreme Court addressed a German national's challenge to his removal pursuant to the Alien Enemy Act of $1798,{ }^{567}$ after the cease-fire between Germany and the U.S. ${ }^{568}$ The Act provided that during a declared war, invasion, or incursion "all natives, citizens, denizens, or subjects of the hostile nation or government, being of the age of fourteen years and upward, who shall be within the United States and not actually naturalized, shall be liable to be apprehended, restrained, secured, and removed as alien enemies." that the President did not have the authority to deport him because at the time of his deportation proceedings, Germany had already unconditionally surrendered to the United States. ${ }^{570}$ Ludecke further asserted that any interpretation allowing the President to deport him after Germany surrendered would render the Act unconstitutional. ${ }^{571}$

The Supreme Court denied Ludecke's petition in a five-to-four decision. Writing for the majority, Justice Frankfurter accepted that the President's power under the Enemy Alien Act necessarily depended on the existence of a declared war, ${ }^{572}$ but rejected the contention that Germany's surrender without a formal peace treaty ended the President's ability to exercise war power under the Act. ${ }^{573}$ Frankfurter observed,

\footnotetext{
564. See Jacobson v. Commonwealth of Mass., 197 U.S. 11, 29 (1905) ("[I]n every well-ordered society charged with the duty of conserving the safety of its members the rights of the individual in respect of his liberty may at times, under the pressure of great dangers, be subjected to such restraint [of free will] to be enforced ... a as the safety of the general public may demand.").

565. 481 U.S. at 747.

566. 335 U.S. 160 (1948).

567. 50 U.S.C. $\S \S 21-24(2000)$.

568. Ludecke, 335 U.S. at 163-65.

569. 50 U.S.C. § 21. The Court characterized the Act as a recognition of the President's plenary power over immigration, which is virtually immune from judicial review. See Ludecke, 335 U.S. at 164 ("The very nature of the President's power to order the removal of all enemy aliens rejects the notion that courts may pass judgment upon the exercise of his discretion.").

570. Ludecke, 335 U.S at 166.

571. See id. at 169-71 (addressing the issues of whether the war had ended and whether the Act was constitutional).

572. Id. at $161-62,166-70$.

573. Id.
} 
"War does not cease with a cease-fire order, and power to be exercised by the President such as that conferred by the Act of 1798 is a process which begins when war is declared but is not exhausted when the shooting stops." 574 The Court urged a "common sense" approach that would allow for the existence of a state of war after the cessation of hostilities so long as the exigencies necessitating the specific war power at issue continued. ${ }^{575}$

There is, however, limiting language in Ludecke. First, the Court was clear that a peace treaty or declaration of peace by the political branches operatively ended a state of war. ${ }^{576}$ Second, the Court indicated that the issue of whether wartime emergencies continued to exist after a cease-fire, thus justifying continued assertion of certain war powers, depended on the nature of the continuing emergency and the power sought by the President. The Court observed,

The war power includes the power "to remedy the evils which have arisen from its rise and progress" and continues during that emergency. Whatever may be the reach of that power, it is plainly adequate to deal with problems of law enforcement which arise during the period of hostilities but do not cease with them. No more is involved here. ${ }^{577}$

In Ludecke, the President sought deportation power, a police power the Court characterized as only fully exercisable after the cessation of the "shooting war." 578 Even the executive-empowering logic of Ludecke, however, would not appear to justify the President in continuing to detain prisoners of war to prevent them from rejoining the enemy after the enemy's unconditional surrender.

Justice Black's dissent, in which justices Douglas, Murphy, and Rutledge joined, represents the more progressive stance on this issue. Justice Black strenuously objected to the notion that a qualified state of war continued even after Germany had surrendered. Characterizing the "idea that we are still at war with Germany" as a "fiction," opined, "I think there is no act of Congress which lends the slightest basis to the claim that after hostilities with a foreign country have ended

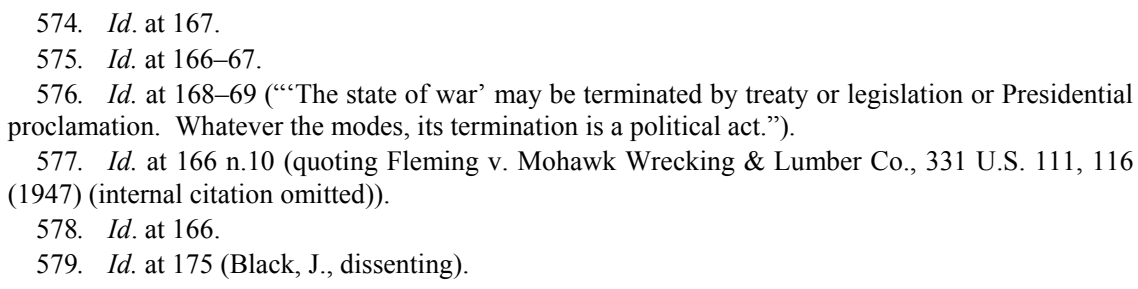


the President or the Attorney General, one or both, can deport aliens without a fair hearing reviewable in the courts." ${ }^{, 580}$ Justice Black further stated that the Enemy Alien Act "did not grant its extraordinary and dangerous powers to be used during the period of fictional wars." ${ }^{581} \mathrm{He}$ also rejected the idea that such aliens were amenable to wartime deportation on the basis of their "potency for mischief." 582 Instead, Black opined that the only justification for their deportation was to prevent acts of sabotage on behalf of an enemy who had ceased to exist. ${ }^{53}$ He observed, "German aliens could not now, if they would, aid the German government in war hostilities against the United States. For as declared by the United States Department of State, June 5, 1945, the German armed forces on land and sea had been completely subjugated and had unconditionally surrendered."

The Hirabayashi and Korematsu cases involved a declared war and temporary detention for the purposes of evacuation. ${ }^{585}$ There was every expectation that the restrictions would be abandoned once a peace treaty was reached. In Hirabayashi the Court specified that the curfew was to last only as long as the danger of war and invasion remained present. ${ }^{586}$ The Court stated, "We need not now attempt to define the ultimate boundaries of the war power. We decide only the issue as we have

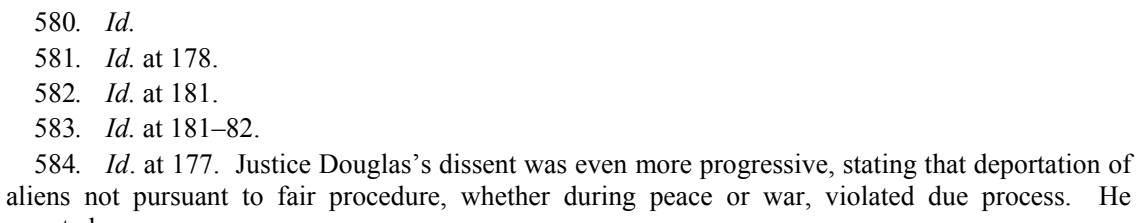

584. Id. at 177. Justice Douglas's dissent was even more progressive, stating that deportation of aliens not pursuant to fair procedure, whether during peace or war, violated due process. He asserted,

A nation at war need not be detained by time-consuming procedures while the enemy bores from within. But with an alien enemy behind bars, that danger has passed. If he is to be deported only after a hearing, our constitutional requirements are that the hearing be a fair one.

Id. at 187 (Douglas, J., dissenting).

585. See Korematsu v. United States, 323 U.S. 214, 219 (1944); Hirabayashi v. United States, 320 U.S. 81, 107 (1943) (Douglas, J., concurring); see also supra notes 341-77 and accompanying text (discussing the triggering conditions of war powers in the internment cases).

586. See Hirabayashi, 320 U.S. at 99. The Court premised the validity of the curfew on the existence of a temporary danger that required immediate redress. The Court compared the curfew order to other temporary emergency measures:

Like every military control of the population of a dangerous zone in war time, it necessarily involves some infringement of individual liberty, just as does the police establishment of fire lines during a fire, or the confinement of people to their houses during an air raid alarm - neither of which could be thought to be an infringement of constitutional right. Like them, the validity of the restraints of the curfew order depends on all the conditions which obtain at the time the curfew is imposed and which support the order imposing it. 
defined it - we decide only that the curfew order as applied, and at the time it was applied, was within the boundaries of the war power." Similarly, in Korematsu, the Court referred to the exclusion order as "temporary" and indicated that it was justified only by the ongoing war with Japan and threat of invasion. ${ }^{588}$

The factual situation presented to the Court in Hamdi was far different from that of the World War II cases. Unlike a conventional wartime conflict, the majority of military activity in Afghanistan had been in the form of an extended occupation rather than a "shooting war." ${ }^{589}$ Once the Taliban government fell and the U.S.-friendly Hamid Karzai was installed as interim prime minister, the United States kept troops deployed in a rather undefined peacekeeping mission. One expert noted,

Four months after the last major military engagement of the Afghan war, the U.S.-led military coalition has more than 10,000 troops on the ground. Their mission has evolved from a clear-cut effort to topple the Taliban and cripple Al Qaeda into an increasingly uncertain operation mired in the complexities of Afghan politics.

Extended occupations are rarely skirmish free, especially in the Arab world where many groups vie for control of regions. ${ }^{591}$ Consequently, to avoid sanctioning indefinite detention, it was imperative for the Court to set up a viable proxy for a peace treaty that would signify the termination of war for the purpose of ending the war power. A logical route might have been to deem the regime change as the triggering factor, given that the enemy fighter could not rejoin an army that no longer existed. ${ }^{592}$ The

587. Id. at 102 (emphasis added).

588. Korematsu, 323 U.S. at 219.

589. See Ludecke, 335 U.S. at 166 (using the term "shooting war"). The war in Afghanistan began in October 2001, and Hamid Karzai was named interim prime minister by December 5, 2001. See Afghan Factions Sign Power Deal, CNN.COM, December 5, 2001, http://archives.cnn.com/2001/ WORLD/europe/12/05/gen.bonn.talks/index.html. For the past three years troops have been deployed in Afghanistan fighting skirmishes and serving security and peacekeeping roles. See U.N.: New Afghan Government in Accord on Peacekeepers, CNN.COM, Dec. 30, 2001, http://archives.cnn. com/2001/WORLD/asiapcf/central/12/30/ret.afghanistan.campaign (stating that the first U.N. peacekeepers arrived in Afghanistan on December 22, 2001).

590. Susan B. Glasser, U.S. Challenged To Define Role In Afghanistan, WASHINGTON POST.COM, Aug. 3, 2002, http://www.washingtonpost.com/ac2/wp-dyn?pagename=article\&node= \& contentId=A38181-2002Aug2\&notFound=true.

591. In Afghanistan, these skirmishes often involve factions with no connection to the former Taliban regime. See Warlord Behind Afghan Rocket Attacks, CNN.COM, Apr. 29, 2002 http://archives.cnn.com/2002/WORLD/asiapcf/central/04/29/afghan.rocket/index.html ("Rivalries between warlords have turned parts of Paktia into warzones, terrifying residents, with some saying they miss the more stringent control of the Taliban.").

592. This was the position urged by Hamdi. See Martinez, supra note 499, at $783-84$ 
Court, however, instead used the presence of troops engaged in fighting to deny that hostilities had ended sufficiently to release military prisoners. ${ }^{593}$ Although the Court formally justified Hamdi's detention by the need to prevent him from rejoining the enemy army, ${ }^{594}$ by the time the Court reviewed Hamdi's case the enemy army had already fallen to U.S. forces. ${ }^{595}$ Thus, upon closer examination, the logic of detaining Hamdi was not the stated reason of preventing him from rejoining an enemy army, but rather preventing him from acting on any decision he might make in the future to participate in insurgent activity.

The concept that wartime detentions may continue after the fall of the enemy government and installation of a U.S.-friendly government goes beyond the scope of even the Ludecke opinion and certainly beyond the time frame contemplated in the internment cases. The Ludecke opinion approved of limited exercise of war-related police powers in the months following termination of the shooting war. ${ }^{596}$ The Hamdi case greatly expands this principle to full detention years after the enemy government has fallen. This broad definition of the length of military detention has precedent neither in domestic law nor customary international law. Experts note that

any authority for detention provided by the Third Geneva Convention may possibly have ceased when the U.S.-friendly government of Hamid Karzai took control of Afghanistan, arguably ending the international armed conflict there. Fighting within the territory of Afghanistan after the change of governments could potentially be classified by international humanitarian law as a non-international armed conflict. ${ }^{5}$

(explaining that the Supreme Court argued that detention was justified so long as U.S. troops were in Afghanistan).

593. Hamdi v. Rumsfeld, 542 U.S. 507, 521 (2004) (holding that Hamdi's detention was justified "[i]f the record establishes that United States troops are still involved in active combat in Afghanistan").

594. Id. at 519 .

595. See supra note 589 (noting that the Taliban government was dismantled by December 5 , 2001)

596. See Ludecke v. Watkins, 335 U.S. 160, 166-67 (1948) (stating that the police power is not necessarily exhausted when the shooting stops and that certain powers such as that of deportation may not be practicable until the shooting stops).

597. Martinez, supra note 499, at 786 . The fact that customary international law is not clear that Hamdi's continued detention is justified by the conflict in Afghanistan makes the Court's conclusion that Congress implicitly authorized Hamdi's detention by the AUMF because of the universality of the law of war even more untenable. Even if the law of war was well settled that Hamdi, despite his citizenship status, could be detained during the relevant conduct, it is very far from clear that the law of war would permit his continued detention after the fall of the Taliban regime. Professor Jenny Martinez remarks, 
Had the Court adopted a similar approach after World War II, the United States could have detained "security threats"-for example, unhappy Japanese internees - for many years after the shooting war, so long as the United States continued to maintain troops in Japan. As a result, the Hamdi decision greatly extended the duration of wartime and allowed for the possibility of prolonged, if not indefinite, detention, even if the military to which the detainee belonged had been dismantled.

\section{CONCLUSION}

The Japanese internment is our country's burden to bear. It is our reminder to "never forget" the atrocious consequences of government overreaching. After 9/11 and the ensuing Bush Administration policies, this reminder resurfaced as a warning that we not be complacent in the face of repression, despite our understandable and grave fears of terrorism. Naturally, the invocation of the internment by civil libertarians engendered a backlash from Bush supporters and securityminded conservatives. Backlash arguments ranged from noxious justifications of the internment to more subtle attempts to distance current policies from the internment through optimistic arguments that society and its laws have progressed. Even the most benign distancing arguments, however, undercut the persuasive power of the internment invocation, much in the way reminders of slavery and gender repression used to fight current discrimination are undermined by the claim that society has "gotten better."

This Article has assessed the claim that society has "gotten better" through a legal prism. Specifically, it has concentrated on four jurisprudential choices made in both the internment and terrorism cases to determine whether the current Supreme Court has progressed in its analysis of wartime presidential powers. The Court's crafting of individual judicial processes for military detention signals some progress from World War II, as the Court definitively moved away from the notion that courts may not sit in judgment of military decisions.

Instead of confronting international humanitarian law, with all its limitations, the Supreme Court appears in Hamdi to have embarked on a questionable path toward creating its own, new constitutional common law of war, ungrounded either in international humanitarian law or in any specific legislation enacted by the U.S. Congress. It may be that international humanitarian law should be modified to respond to the changing factual circumstances of contemporary armed conflict, but the U.S. Supreme Court seems a body particularly ill suited by institutional competence to be the Id. at 787.

principal author of this new regime. 
However, other choices made in the terrorism cases do not manifest progress and in fact seem to indicate regression. The Court made it much easier for the political branches to exercise war power and detain individuals outside normal criminal processes. It definitively approved of military detention of U.S. citizens, resolving the conflict between Quirin and Milligan in the least progressive way, and cementing the precedential value of the oft-criticized Quirin opinion. While not going so far as granting the executive unilateral authority to exercise wartime detention powers, the Court greatly reduced the role of Congress in authorizing detentions. Relying on the sparse AUMF and the "clear" law of war, the Court required neither explicit nor implicit congressional approval for citizen detention. The Court moreover approved of military detention that was carried out, not according to the dictates of the Geneva Convention, but rather in jails, solitary confinement, and criminal conditions. Finally, the Court's "troops on the ground" analysis allowed military detention to be prolonged beyond what was contemplated in the World War II cases and possibly indefinitely.

If we are to "step out a bit from the shadow" 598 of the internment, our laws must step into the light. By treating Hamdi as if he were a prisoner of war captured in a traditional declared armed conflict, the Court has greatly augmented the government's ability to exercise wartime detention power. The fact is that the War on Terror is vague and may never end, and the Court must construct realistic limits on military detention power that make sense given current political realities. To the extent that the Court has actually expanded rather than restricted the detention power, cautionary tales of past abuses remain relevant. Defenders of civil liberties must therefore continue to raise the red flag, be vigilant about government overreaching, and passionately invoke the caution of the internment. 